\title{
FAL-MARKS on PLATE.
}

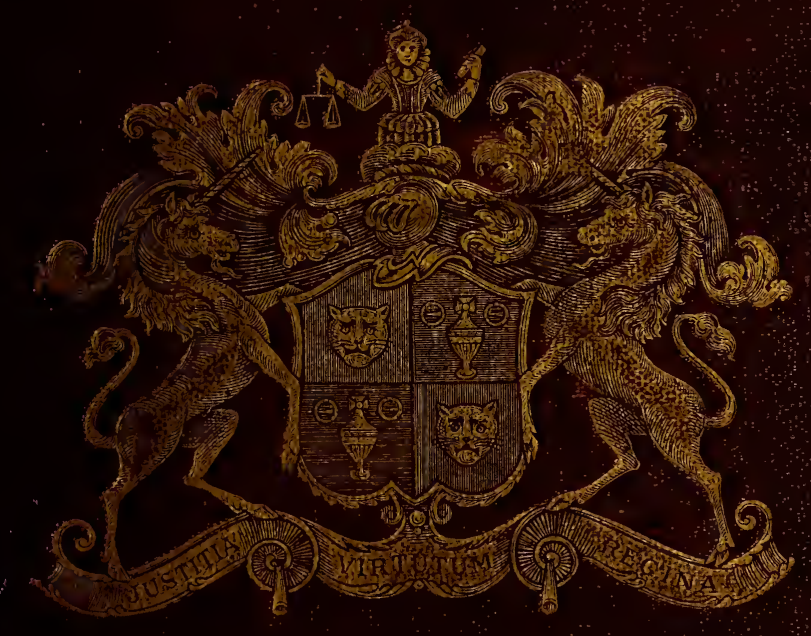

W. CHAFFERS. 


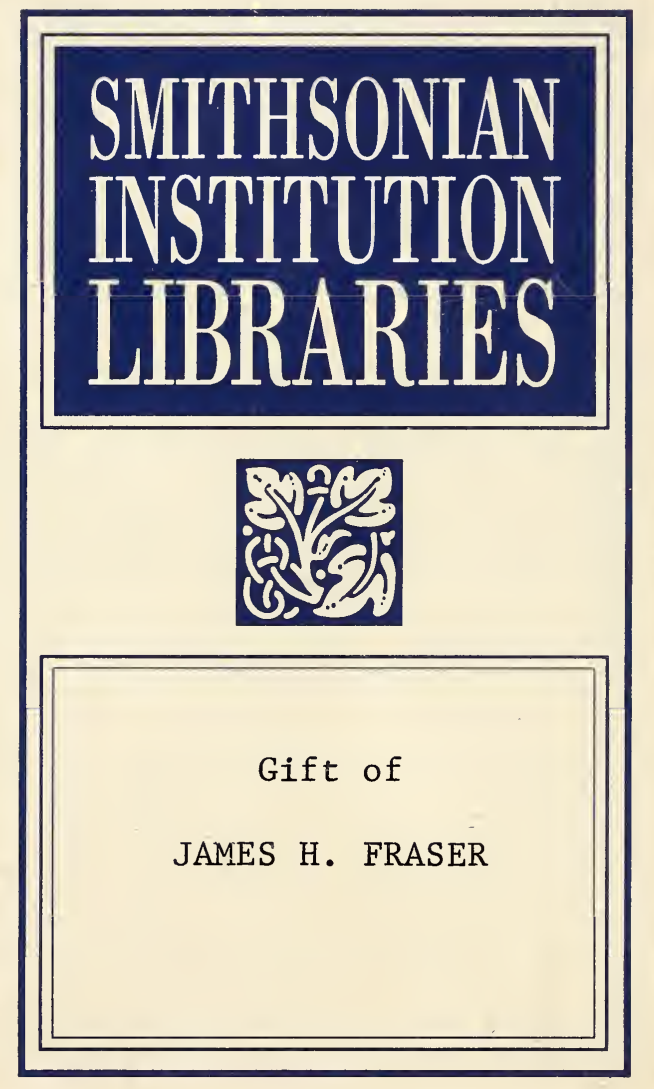









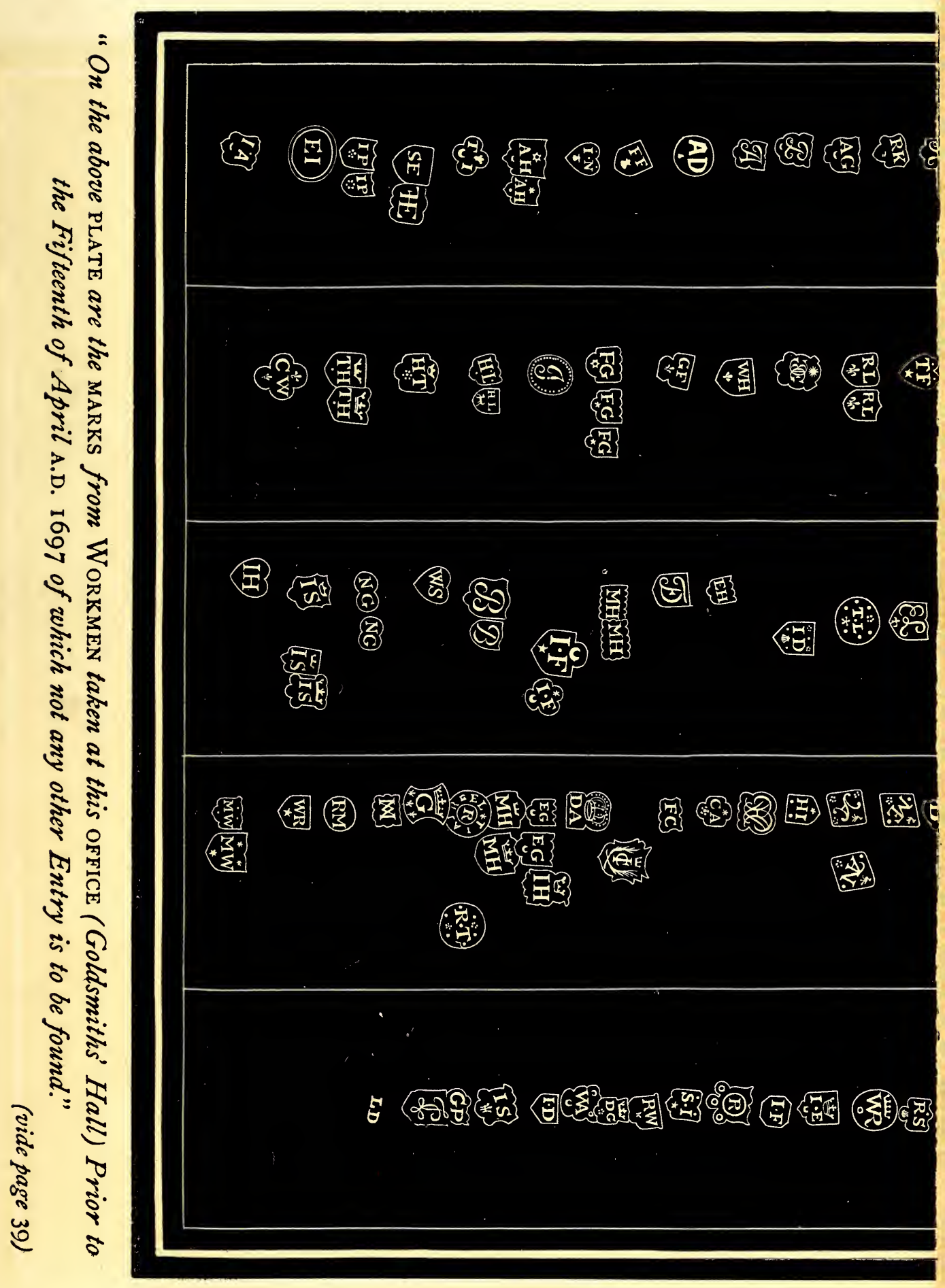




\section{THE LIBRARY \\ FAIRLEIGH DICKINSON \\ UN IVERSITY}

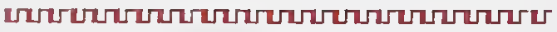

PRESENTED BY

EMMA JOY DANA

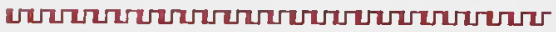

Florbam-Madison Campus

Madison, N.J. 


\begin{tabular}{|c|c|c|c|c|}
\hline 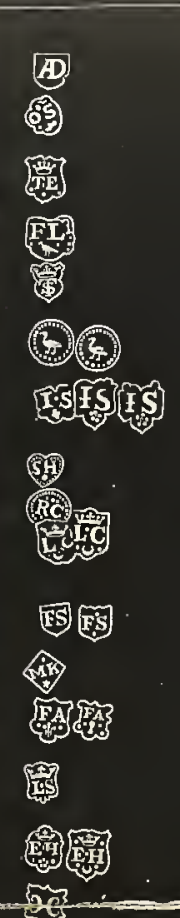 & 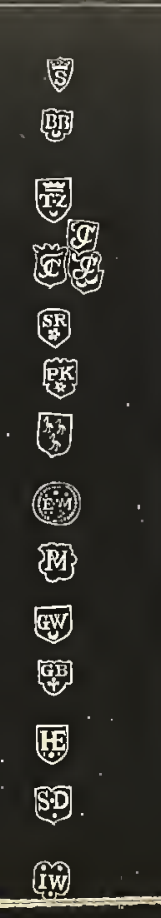 & 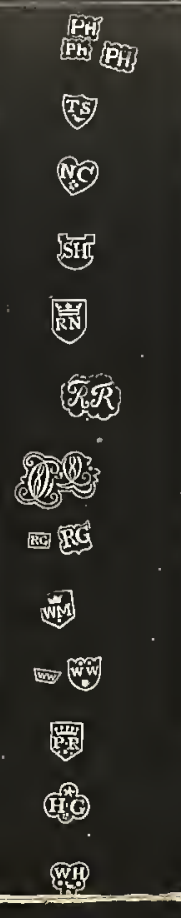 & 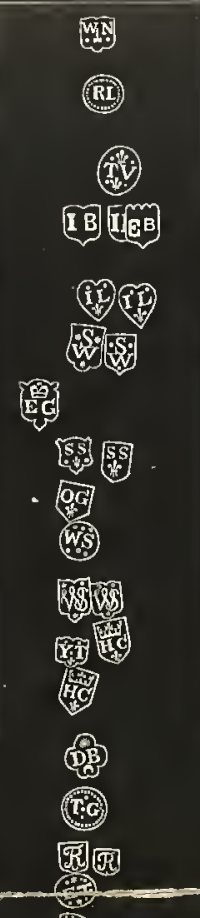 & 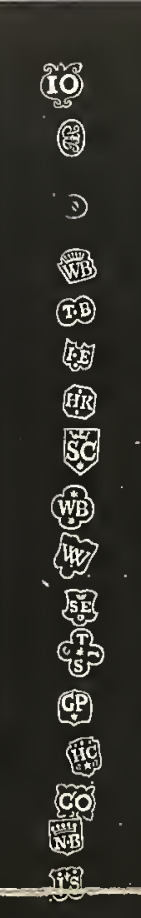 \\
\hline 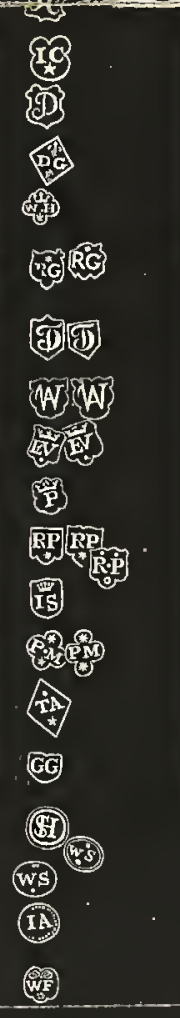 & 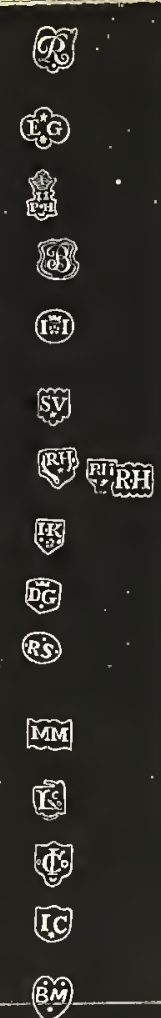 & 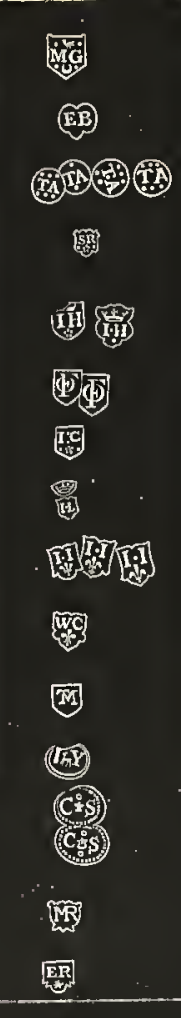 & 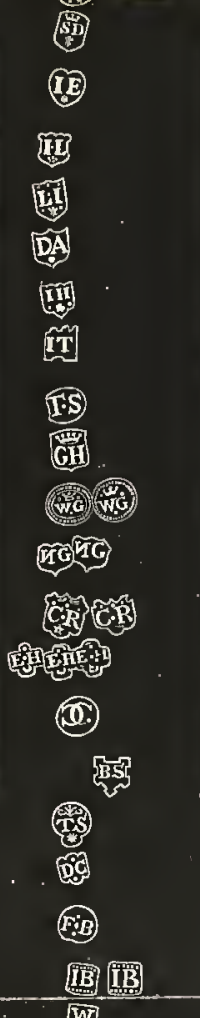 & 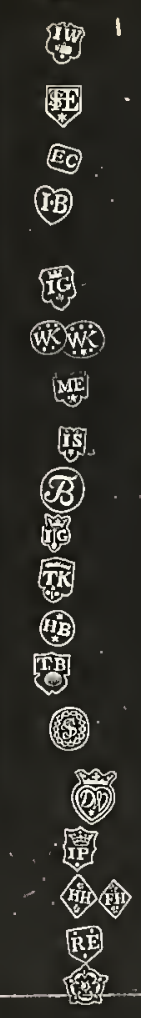 \\
\hline 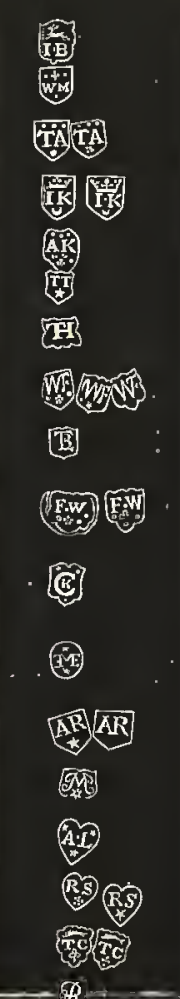 & 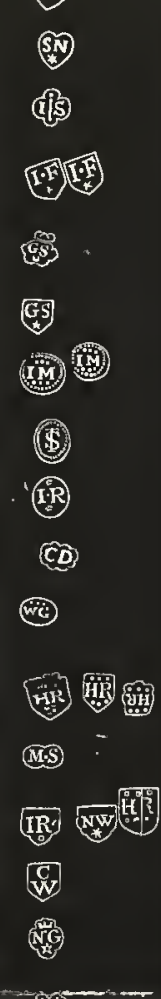 & 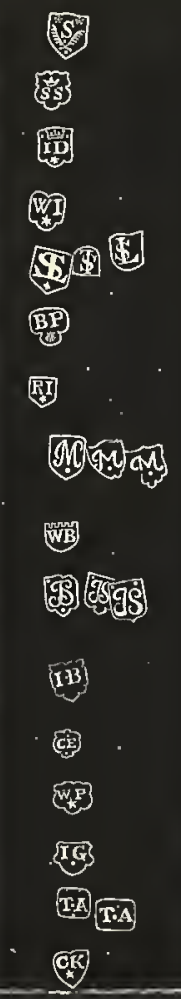 & 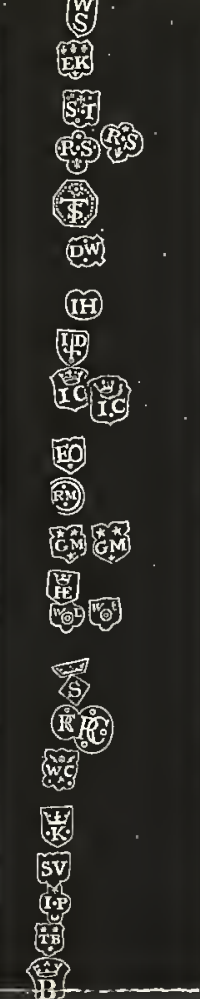 & 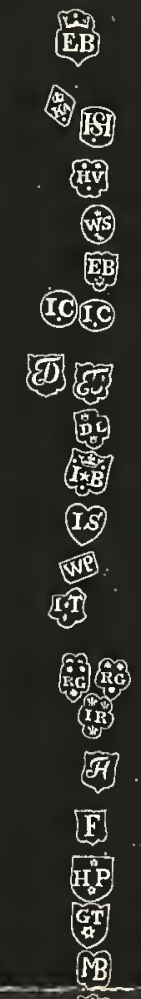 \\
\hline 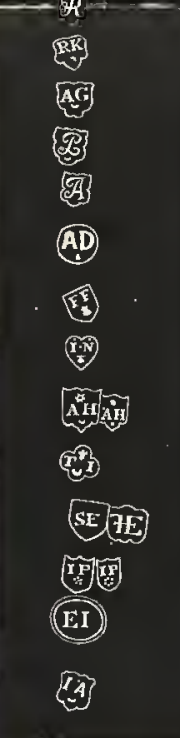 & 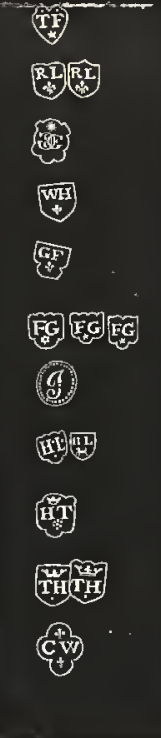 & 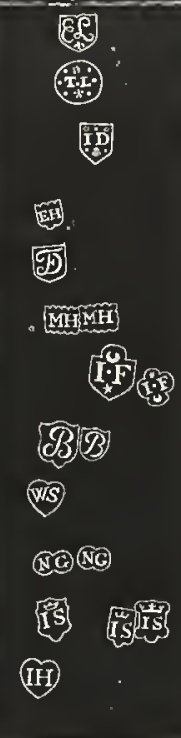 & 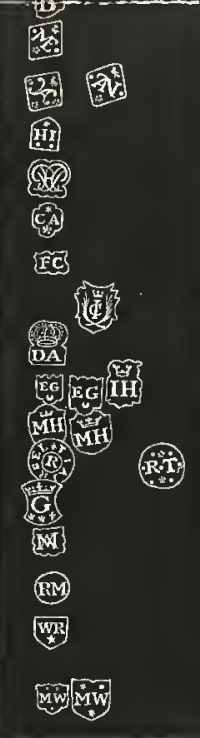 & 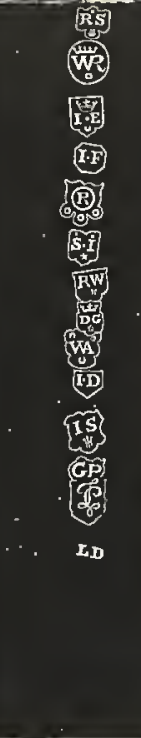 \\
\hline
\end{tabular}

"On the above PLATE are the MARKS from WoRKMEN taken at this OFFICE (Goldsmith' Hall) Prior to the Fifteenth of April A.D. 1697 of which not any other Entry is to be found." 



\section{HALL MARKS}

GOLD AND SILVER PLATE. 
'THIS FAC-SIMILE does not contain the whole of the makers' marks on the copper plate, but only the largest sized punches as therein arranged, on the first five columns. A Photograph (the size of the original) containing both large and small stamps, may be obtained (price Five Shillings) of Mr. W. Chaffers, No. 19, Fitzroy Square, W. 


\section{4,50

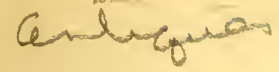

NK

7210

c $4 x$

\section{HALL MARKS}

1872

ON

GOLD AND SILVER PLATE,

ILLUSTRATED WITH

TABLES OF ANNUAL DATE LETTERS

EMPLOYED IN THE

\section{Assap @ffices of England, Sivotland \& Jreland,}

A FAC-SIMILE OF A COPPER-PLATE OF MAKERS' MARKS AT GOLDSMITHS' HALL,

A PLATE OF FRENCH STANDARD AND ASSAY STAMPS, Soc. Esc.

BY

WILLIAM CHAFFERS,

AUTHOR OF "MARKS AND MONOGRAMS ON POTTERY AND PORCELAIN," "THE KERAMIC GALLERY," "PRICED CATALOGUE OF COINS," "OBJECTS OF INTEREST AT THE LEEDS NATIONAL EXHIBITION OF WORKS OF ART IN I868, ILLUSTRATED BY PHOTOGRAPHS," ETC.

FOURTH EDITION, REVISED AND CONSIDERABLY AUGMENTED.

\section{LONDON :}

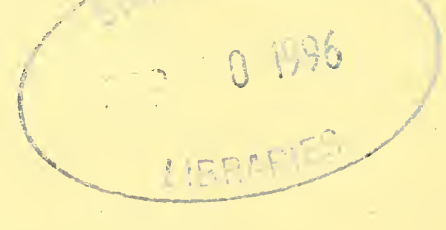

J. DAVY \& SONS, I37, LONG ACRE.

CIJ.IJCCC.LXXII. 
DRYDEN PRESS :

-J. DAVY AND SONS, I37, LONG ACRE,

THE RIGHT OF TRANSLATION RESERVED

Entered at Stationers' Hall. 


\section{HALL MARKS ON PLATE}

FROM THE

\section{Chirtenth to the §ineteentb $\mathbb{C e n t u r y . ~}$}

\section{TABLE OF STATU'TES AND ORDINANCES}

\section{REFERRED TO IN THIS BOOK.}

A.D.

1238. 22 Henry III. cl. m. 6 . 1300. 28 Edward I. c. 20.

1327. Charter 1 Edward III.

1336. Ordinance of the Goldsmiths' Company.

1363. 37 Edward III. c. 7 .

1369. 43 Edward III. cl. m. 35.

1379. 2 Richard II.

1392. Charter 16 Richard II.

1403. 5 Henry IV. c. 13.

1414. 2 Henry V.c. 4.

1420. 8 Henry V.c. 3 .

1423. 2 Henry VI. c. 14.

1457. James II. (Scots).

1462. Charter 2 Edward IV.

1473. James III. (Scots).

1477. 17 Edward IV. c. 1.

1483. James III. (Scots).

1488. 4 Henry VII. Parl. 3, c. 2.

1504. Charter 20 Henry VII.

1555. Mary (Scots).

1573. 15 Elizabeth.

1576. 18 Elizabeth, c. 15.

1587. James VI. (Scots).

1597. Goldsmiths' Company Records.

1638. Charter of Charles I. (Irish).

1675. Goldsmiths' Order.
A.D.

1687. Charter of James VII. (Scots).

1697. $8 \& 9$ William III. c. 8 . 1698. $9 \& 10$ William III. c. 28. 1700-1. $12 \& 13$ William III. c. 4. 1702. 1 Anne, c. 9.

1719. 6 George I. c. 11.

1730. 3 George II. (Irish).

1739. 12 George II. c. 26.

1756. 29 George II. c. 14.

1758. 31 George II. c. 32 .

1759. 32 George II. c. 14.

1773. 13 George III. c. 52.

1784. 24 George III.

1785. 25 George III. c. 64.

1790. 30 George III. c. 31 .

1797. 37 George III. c. 90 .

1798. 38 George III. c. 69 .

1803. 43 George III. c. 69 .

1804. 44 George III. c. 98.

1807. 47 George III.

1815. 55 George III. c. 185.

1819. 59 George III.

1824. 5 George IV.

1825. 6 George IV.

1836. 6 William IV.

1844. $5 \& 6$ Vic., c. $47 \&$ c. 56 .

1845. $7 \& 8$ Victoria, c. 22 .

1854. $17 \& 18$ Victoria. 


\section{THE GOLDSMITHS' COMPANY.}

The following account of the Goldsmiths' Company is from a plate of their arms in the Secretary's office :-

"To the Master, Warden and Wardens with the rest of the worthy Members of the $\mathrm{R}^{\mathrm{t}}$ Worsh ${ }^{11}$ Comp $\mathrm{y}^{\mathrm{y}}$ of Goldsmiths.

$T B$ wisheth event of all Felicity and humbly dedicates this plate.

The $\mathrm{R}^{\mathrm{t}}$ Worsh ${ }^{11}$ company of Goldsmiths, London, bear for their Ensigne Armoriall: Quarterly, gules and azure; In the 1st and 4th a Leopard's head Or. In the 2nd and 3rd a Cup covered between two Buckles of the last. On a helmet a wreath of their colours; A denty* Lady her arms extended proper, in the dexter hand a pair of scales, and in the sinister an ingot as the third. Supported by two Unicorns, gold. Underneath on an Escrole for their motto justitia virtutum Regina. Patron St. Dunstan.

"It is to the very great honour of this Company, that severall persons of eminent worth in Antient and Modern times, have been inrolled among them (particularly) in the reigne of Henry the 1st Leofstane goldsmith was Provost of this City. That Henry Fitz Alwyn Fitz Leofstane goldsmith was Maior of London, 1st of Richard 1st 1189. That Gregory Rokesby goldsmith continued Maior 7 year together. That Will ${ }^{\mathrm{m}}$ Farringdon goldsmith was Sheriff 9 th of Edward 1st 1280. And his son Nicholas after him Lord Maior 4 times in the reigne of Edw ${ }^{\mathrm{d}}$ 2nd 1308. Besides King Prince Earle Lord and Lord Maiors. They were incorporated 16th Richard 2nd, 1392. $\mathrm{W}^{\mathrm{m}}$ Stonden Lord Maior; Gilbert Mafield Thos Newington, Sheriffs.

Their Mansion Hall scituate Foster Lane London.

"Printed for T. Bower Painter and are to be sold at his shop at the King's Head in Budge Row, London."

Their crest and supporters were granted in 1591.

\footnotetext{
* Dainty, an old word for fine or elegant, here used for an elegantly dressed
} lady. 


\title{
EXT'RACTS FROM STATUTES AND ORDINANCES
}

REGULATING THE

\author{
MANUFACTURE AND STAMPING OF PLATE IN ENGLAND,
}

WITH EXPLANATORY NOTES.

GowD and Silver in a pure state would be too soft and ductile to be employed either in the manufacture of vessels for ordinary use, or for the coinage of the Realm; it has accordingly been found necessary to add a certain proportion of the baser metals to make them sufficiently hard for the purpose. As this necessity deteriorates the value, and as the goldsmith who manufactures them into vessels must himself introduce the inferior metals, it will be easily seen that a great means of deception is hereby placed in the hands of a dishonest worker, which the purchaser would not (without some difficulty) be able to discover. Hence, from the earliest times, a certain standard of fineness has been insisted on by the laws of the land, any departure from which has been visited with severe penalties.

This introduction of inferior metals is called the allay or alloy, and is supposed to be derived from $\grave{a} l a l o i$, being the proportion of silver or copper, or both mixed together, according to the law regulating the standard. The author of the Touchstone for Gold and Silver Wares, in 1667, says: "Our forefathers, considering that silver in its finest degree would be too soft for use and service (for the finest silver is almost as soft as lead) did consult to reduce or hardèn the silver, by alloying it with baser metal, to such a degree that it might be both serviceable in the works, and also in the wearing keep in native whiteness."

The first instance on record of an attempt to reduce goldsmiths' work to a certain standard, was in the reign of Henry III. A.D. 1238 (Claus. 22, Henry III. m. 6), when, in consequence of the frauds which had been practised by the gold and silversmiths, it became necessary to prescribe some regulations for their trade, because the mixing too much alloy in the composition of these wares naturally tended to encourage the melting down of the coin of the realm. It was therefore ordained that no one should use any gold of which the mark was not worth one hundred shillings at the least, nor any silver worse than the standard of the coins.

The assay of gold and silver is said to have originated with the 
Bishop of Salisbury, Royal Treasurer to Henry I., but some sort of test was adopted from the earliest times in this country, and this test was probably by means of the touch: that is, by judging of the quality of the metal when rubbed on a stone; this method is still in use for ordinary purposes, and a practised eye can immediately detect the quantity of alloy by the shades of colour of the metal so transferred to the touchstone.

The touchstone is a black stone of a close, fine grain; the way it was used is thus described in the Touchstone for Gold and Silver Wares, A.D. 1667, before quoted: "The way to make a true touch on the touchstone is this, rub the gold or silver steadily and very hard upon the stone, not spreading your touch above a quarter of an inch long, and no broader than the thickness of a five shilling piece of silver, and so continue rubbing until the place of the stone whereon you rub be like the metal itself; and when every sort is rubbed on at the time you intend, wet all the touched places with your tongue, and it will show itself in its own countenance."

In another plan for the trial of gold, two sets of touch needles or bars were used, one set alloyed with copper, and the other with silver, 24 in each set, according to the 24 carats fineness of gold. The streak or touch of the piece to be examined was compared with the streaks made by the needles, being washed with aquafortis, and thus its fineness was determined.

The assaying of the precious metals was a privilege conferred upon the Goldsmiths' Company by the following statute:-

A.D. 1300.28 EDWard I., c. 20, commonly called Articuli super cartas. "It is ordained, that no goldsmith of England, nor none otherwhere within the Kings dominions, shall from henceforth make or cause to be made any manner of vessel, jewel, or any other thing of gold or silver, except it be of the true allay, (that is to say) gold of a certain touch, and silver of the sterling allay, or of better at the pleasure of him to whom the work belongeth; and that none work worse silver than money; and that no manner of vessel of silver depart out of the hands of the workers, until it be assayed by the wardens of the craft; and further, that it be marked with the leopard's head; and that they work no worse gold than of the touch of Paris; and that the wardens of the craft shall go from shop to shop among the goldsmiths, to assay, if their gold be of the same touch that is spoken of before; and if 
they find any other than of the touch aforesaid, the gold shall be forfeit to the king:* [and that none shall make rings, crosses, nor locks:] and that none shall set any stone in gold except it be natural ; and that gravers or cutters of stones, and of seals, shall give to each their weight of silver and gold as near as they can upon their fidelity; and the jewels of base gold which they have in their hands, they shall utter as fast as they can; and from thenceforth if they buy any of the same work, they shall buy it to work upon and not to sell again; and that all the good towns of England where any goldsmith be dwelling, shall be ordered according to this statute as they of London be; and that one shall come from every good town for all the residue that be dwelling in the same, unto London for to be ascertained of their touch. And if any goldsmith be attainted hereafter, because that he has done otherwise than before is ordained, he shall be punished by imprisonment, and by ransome at the king's pleasure," \&c.

The touch of Paris was referred to in this statute because there were no English gold coins which could be made a standard for the goldsmiths' work. The French coins of that time were of fine gold. The touch of Paris therefore was as celebrated over Europe as the sterling of England.

A.D. 1327. 1 EDWard III., the first Charter to the Goldsmiths' Company bears date 30th March, and recites the deceits of the cutlers, in "covering tin with silver so subtilly and with such sleight, that the same cannot be discerned and severed from the tin, and by that means they sell the tin so covered for fine silver," and empowers the Company to punish such offenders; and " that in all cities and towns in England where goldsmiths reside, one or two of every such city or town, for the rest of that trade shall come to London to be ascertained of their touch and there to have a stamp of a puncheon of a Leopard's head, marked upon their work, as of ancient time it has been ordained."

The Company's Ordinances of the year 1336 enjoin, that none do work gold unless it be as good as the assay of the mystery; or in silver, unless as good or better than the king's coin or sterling, and that when done, it shall be brought to the Hall to be assayed, and that such as will bear the touch shall be marked "with the

* That portion between brackets relating to rings, crosses and locks, repealed 21 Jac. 28. 
owners and sayers marks, and afterwards be touched with the Liberdshede crowned."

It will be observed here that three distinct marks are spoken of-1. The goldsmith's mark, viz., his initials; 2 . The assay mark, probably a letter of the alphabet; and 3. The mark of the Goldsmiths' Hall, a leopard's head crowned.

A.D. 1363. 37 EDWARD III. c. 7. "Item, it is accorded that goldsmiths as well in London as elsewhere within the realm, shall make all manner of vessels and other work of silver, well and lawfully of the allay of good sterling; and every master goldsmith shall have a mark by himself, and the same mark shall be known by them which shall be assigned by the King to survey their work and allay; and that the said goldsmiths set not their marks upon their works, till the said surveyors have made their assay, as shall be ordained by the King and his council: and after the assay made, the surveyor shall set the Kings mark, and after the goldsmith his mark, for which he will answer; and that no goldsmith take for vessel white and full for the weight of a pound (that is to say) of the price of two marks of Paris weight, but eighteen pence as they do in Paris ;* [and that no goldsmith making white vessel shall meddle with gilding, nor they that do gild shall meddle to make white vessel:] and they which shall be so assigned in every town shall make their searches as oftentimes as shall be ordained; and for that which shall be in the goldsmiths default they shall incur the pain of forfeiture to the King, the value of the metal which shall be found in default."

The laws which regulated the goldsmith's trade were rigorously enforced, and we read (Cl. 43 Edw. III. m. 35) that William de Mulsho and John de Newenham, in 1369, were commanded to examine by the touch, or by other methods, certain vessels of silver, and belts of gold, which William de Montacute, Earl of Salisbury, had caused to be made by goldsmiths of London of less fineness than the ordinance required, and to report the assay to the King in chancery.

A.D. 1379. 2 RICHARD II. It was enacted by Parliament that, whereas the gold and silver worked by English goldsmiths was oftentimes less fine than it ought to be, because the goldsmiths were their own assayers, from that time every goldsmith should

* This clause in brackets about gilding was repealed 21st Jac. 18. 
have his own proper mark upon his work, and that the assay of touch should belong to the mayors and governors of cities and boroughs, with the assistance of the Master of the Mint, if there should be occasion; and that the work should bear the mark of the city or borough where it was assayed. And also that the King should assign such persons as he should please to make the said assay, as well in London as elsewhere, as often as should be necessary; and after the assay should be made, to stamp the wort with another mark, to be appointed by the King. And it was agreed that the ordinance should commence from the said feast of St. John, and continue until the next Parliament, to try whether it would be advantageous or not.

A.D. 1392. 16 RichaRd II. Another Charter to the Goldsmiths' Company bearing date the 6th of February of this year, granted and gave licence to the men of the said craft of goldsmiths of the City of London to be a perpetual community or Society of themselves, and elect yearly out of themselves four wardens to oversee, rule, and duly govern the said craft and community.

A.D. 1403. 5 Henry IV. c. 13. Recites, "That many fraudulent artificers do daily make locks, \&c., of copper and latten, and the same do over gild and silver like to gold and silver, to the great deceit, loss and hindrance of the common people, and the wasting of gold and silver ;" and ordains, "That no artificer, nor other man, shall gild nor silver any such locks, rings, beads, candlesticks, harness for girdles (buckles), chalices, hilts nor pommels of swords, powder boxes nor covers for cups, made of copper or latten, upon pain to forfeit to the King 100 shillings every time, and to make satisfaction to the party grieved for his damages; but that (chalices always excepted) the said artificers may work ornaments for the Church of copper and latten, and the same gild or silver, so that always in the foot or some other part of such ornament the copper and latten shall be plain, that a man may see whereof the thing is made, for to eschew the deceit aforesaid."*

A.D. 1405. A contest happened between the Companies of the Goldsmiths and Cutlers, with regard to certain privileges, claimed by the former, of inspecting all the gold and silver work made by

* Louis XI. King of France, in an ordinance to the goldsmiths of Tours, January, 1470, authorizes them to employ only for ecclesiastical utensils, such as reliquaries, \&c., gold and silver of base alloy, which pieces were to be inscribed "non verundetur," to certify that they were not destined for commerce. 
the latter. At length the goldsmiths appealed to the Parliament, and by the authority of the King, the affair was referred to the Lord Mayor of London, who, having carefully examined into the affair, reported, that according to the ancient immunities of the City, the cutlers had a right to work in gold and silver; but that all things made by them were to be assayed by the goldsmiths; whereupon the Goldsmiths' Charter was confirmed by Parliament, and additional privileges were granted.

A.D. 1414. 2 Henry V. c. 4. Ordains, "That all goldsmiths of England shall gild no silver wares but of the allay of the English sterling, on forfeiture to the King of the value of the thing sold."

A.D. 1420. $8 \mathrm{HENRY}$ V. c. 3. Ordains, "That none shall gild any sheaths, nor metal but silver and Church ornaments; nor shall silver no metal but Knight's spurs, and all the apparel that pertaineth to a Baron, and above that estate: upon pain of forfeiture to the King ten times as much as the thing so gilt is of value, and shall have one year's imprisonment."

This statute seems to have been made because the two last were found ineffectual to prevent frauds.

A.D. 1423. 2 Henry VI. c. 14. "It was ordained that no goldsmith or worker of silver within the City of London sell no workmanship of silver, unless it be as fine as the sterling; and that no goldsmith, nor jeweller, nor any other that worketh harness of silver, shall set any of the same to sell within the city, before that it be touched with the touch, and also with a mark or sign of the workman of the same, upon pain of forfeiture of the double value thereof. And that the mark or sign of every goldsmith be known to the wardens of the craft. And if it may be found that the said Keeper of the Touch touch any such harness with the leopard's head, except it be as fine in allay as the sterling, that then he shall forfeit for every thing so proved, the double value to the King, and to the party who shall prove it. And it is also ordained that in the city of York, Newcastle-upon-Tyne, Lincoln, Norwich, Bristol, Salisbury and Coventry, there shall be divers touches, arcording to the ordinance of Mayors, Bailiffs, or Governors of the said towns. And that no goldsmith, nor other workers of silver, nor Keepers of the said touches, within the said towns, shall set to sell, nor touch any silver in other manner than is ordained before within the City of London, upon pain of the said forfeiture." 
A.D. 1462. 2 Edward IV. Another Charter to the Goldsmiths' Company in London bears date 30th May, and grants (inter alia) as follows :-

"The Wardens and Commonality and their successors for ever, the search, inspection, trial, and regulation of all sorts of gold and silver wrought, or to be wrought, and to be exposed to sale within the City of London and the suburbs thereof, and in all fairs and markets, and all cities, towns and boroughs, and all other places whatsoever throughout our Kingdom of England; and also shall have power to punish and correct all defects that shall be found in the working of gold and silver," and this privilege has been since so materially enlarged, that they have the power of inspecting all gold and silver wares in the following particular places, viz. Chester, Newcastle, Norwich, Exeter, Birmingham and Sheffield, with the power of punishing all offenders concerned in working adulterated gold and silver, and of making bye-laws for their better government.

A.D. 1477. 17 EDWARd IV. A statute made in this year recites the Act of 2 Henry VI. above quoted, which ordained that goldsmiths' work of silver should be as fine as sterling, and that it should be marked with the touch of the leopard's head. And as that Act had been daily broken by goldsmiths and other workers of silver, the fineness of the gold wares was fixed at 18 carats, and the silver at the same as sterling, on pain of forfeiture of the double value; and further enacts that no work of silver should be exposed to sale, within the City of London, or two miles of the same, until it had been marked with the touch of the leopard's head crowned, and also with the mark of the worker of the same. This Act continued for seven years, and was afterwards re-enacted for twenty years in 1489, and again for twenty years in 1552, by Edward VI.

A.D. 1488. 4 Henry VII. PARL. 3, c. 2, sets forth, "That it was of old time used and continued till now of late years, that there was, for the avail of the King and the Realm, Finers and Parters of gold and silver by fire and water, under a Rule and Order belonging to the Mints of London, Calais, Canterbury, York, and Durham, and other places where mints be holden, and at the Goldsmiths' Hall in London, to fine and part all gold and silver, belonging and needful for the said Mints and Fellowship of Goldsmiths, for the amendment of money and plate of the realm : that 
everything might be reformed to the right standard, as well in money as plate, to the least cost, for the weal of the King's noblemen of the land and common people. But now that such finers and parters dwell abroad in every part of this realm, out of the Rules aforesaid, and buy gilt silver from the mints, changes and goldsmiths, and part and fine it ; and for the most part of the silver so fined, they do allay in divers manners; and sell it to every man that will buy of them, to make such works as pleaseth the buyers; therefore man can get no fine silver, when they need it, for their money, for the amendment of money and plate as hath been in times past, wherefore it causeth money and plate, in divers places of the realm, to be made worse in fineness than it should be, as it appeareth evidently in divers places, to the great hurt of the King's noblemen and common people." And enacts, "That no Finer nor Parter of gold and silver allay any fine silver or gold, ne none sell in any otherwise, ne to any person or persons, but only to the officers of mints, changes, and goldsmiths within this realm, for augmentation and amending of coin and plate; ne that no Finer nor Parter sell to no person any manner of silver in mass, molten and allayed, on forfeiture of the same,-one half to the King, and the other half to the finder, that can prove and will sue for it in the Exchequer."*

A.D. 1504. Another Charter granted to the Goldsmiths' Company bearing date 3rd February, 20 Henry VII., mentions " that divers persons in divers parts of this Kingdom do work and expose to sale gold and silver wrought worse than standard, and neither fear nor doubt to be punished; as due search, or due punishment, is seldom executed out of London. And that the common standard, or assize of gold and silver (according to the ordinances in that behalf made) is kept in Goldsmiths' Hall in London; and that all works and wares in gold and silver there tried and assayed, and affirmed for good, shall be stamped with their marks, which they use for that purpose; and all defective works utterly condemned."

A.D. 1573. 15 Elizabeth. Commissioners were appointed to enquire into the standard of gold and silver, which had not been attended to, in consequence of the disgraceful state of the coinage, and the low degree of baseness in which that and goldsmiths'

* As this Act makes no mention of any Country Assay Offices, it is probable that all or most of them were now discontinued. 
work generally had recently fallen, but which had then got again to its former purity. The Commissioners called before them the Master and Wardens of the Goldsmiths' Company, to see how far they had complied with the standard; and they were compelled to give security that in future no gold wares should be of less fineness than 22 carats, and silver wares $11 \mathrm{oz} .2 \mathrm{dwts}$. in the pound.

A.D. 1576. 18 Elizabeth. In this Parliament, the abuses in goldsmiths' work were taken into consideration; and it was enacted that, after the 20th of April, no goldsmith should work, sell, or exchange, or cause to be sold, \&c., any wares of gold less in fineness than 22 carats, and that he should use no sother, amell, or other stuffings whatsoever, more than should be necessary, and that he should not take above the rate of twelve pence for the ounce of gold, besides the fashion, more than the buyer should or might be allowed for the same at the Queen's Exchange or Mint, upon pain to forfeit the value of the thing so sold or exchanged.

That he should not put to sale any wares, \&c., of silver before he should have set his mark thereon, to so much as might conveniently bear it, upon pain of forfeiture of the same. And if in any goldsmith's ware, \&c., touched, marked, and allowed for good by the Wardens and Corporation of that mystery, after the said 20th of April, there should be found any falsehood or deceit, then the Wardens and Corporation of that mystery, for the time being, should forfeit the value of the said wares.

The Goldsmiths' Company of London is entrusted with the custody of the pile of troy weights made in this Queen's reign and no country office is mentioned in this Act.

A.D. 1597. In the Records of the Company, is an entry, dated 4th May, 1597, giving an account of an information filed against two goldsmiths for fraud, "in making divers parcels of counterfeit plate debased, and worse than her Majesty's standard, and to give appearance to the said counterfeit plate, being good and lawful, did thereto put and counterfeit the marks of her Majesty's lion, the leopard's head, limited by statute, and the alphabetical mark approved by ordinance amongst themselves, which are the private marks of the Goldsmiths' Hall, and be and remain in the custody of the said Wardens, and puncheons to be worked and imprinted thereon, and did afterwards sell the same for good and sufficient plate, to the defrauding of her Majesty's subjects," \&c. They 
were convicted and sentenced to stand in the pillory at Westminster, with their ears nailed thereto, and with papers above their heads stating their offence to be "For making false plate and counterfeiting her Majesty's touch." They were then put in the pillory at Cheapside, had one ear cut off, and were taken through Foster Lane to Fleet Prison, and had to pay a fine of ten marks.* Although this is the first mention of Her Majesty's lion, or lion passant, and the alphabetical mark, yet they were both used long before this date. The lion passant is first found on plate of the year 1545, and the alphabetical mark was doubtless used since the first Charter was granted to the Goldsmiths' Company in 1327, and is alluded to in an ordinance of 1336 as the " assayer's mark."

\section{'THE GOLDSMITHS' ORDER.}

\section{Goldsmiths' Hall, 23rd February, 1675.}

Whereas complaint hath been made to the Wardens of the Company of Goldsmiths, London, that divers small works, as buckles for belts, silver hilts, and the pieces thereto belonging, with divers other small wares, both of gold and silver, are frequently wrought and put to sale by divers goldsmiths and others, worse than standard, to the great abuse of his Majesty's good subjects, and great discredit of that manufacture, and reproach in foreign parts to the English goldsmiths; and that there are also divers pieces of silver plate sold, not being assayed at Goldsmiths' Hall, and so not marked with the leopard's head crowned, or lyon, as by law the same ought to be: And whereas the Wardens of the said Company, to prevent the said frauds, have formerly required all persons to forbear putting to sale any adulterate wares, either of gold or silver; but that they cause the same forthwith to be defaced: And that as well plate workers as small workers shall cause their respective marks to be brought to Goldsmiths' Hall, and there strike the same in a table kept in the Assay Office; and likewise enter their names and places of habi-

* This was the usual punishment for similar offences. In Belgium it was slightly varied. The goldsmith convicted of having fabricated base gold or silver was led to the market place, and there had his ear nailed to a pillar, where he remained, thus fixed, until he released himself by leaving a piece of his ear behind him. 
tations in a book there kept for that purpose, whereby the persons and their marks might be known unto the Wardens of the said Company; which having not hitherto been duly observed, and many of the offenders seem to be incorrigible; these are therefore to give notice to, and to require again all those who exercise the said art or mystery of goldsmiths in or about the cities of London and Westminster and the suburbs of the same, that they forthwith repair to Goldsmiths' Hall and there strike their marks, first approved by the Wardens in Court, in a table appointed for that purpose, and likewise enter their names with the places of their respective dwellings in a book remaining in the Assay Office there. And that as well the worker as shopkeeper, and all cutlers and girdlers and all others working or trading in gold or silver wares of what kind soever or quality they be, forbear putting to sale any of the said works, not being agreeable to standard, that is to say, gold not less in fineness than 22 carats, and silver not less in fineness than 11 oz. 2 dwts.; and that no person or persons do from henceforth put to sale any of the said wares, either small or great, before the workman's mark be struck clear and visible thereon, and upon every part thereof that is wrought asunder and afterwards sodered or made fast thereto, in finishing the same, unless it be such sort of work adjudged by the Wardens, that it will not conveniently bear the worker's mark. And that all manner of silver vessels, and all manner of silver hilts for swords, and all manner of silver buckles for belts and girdles, and other harness of silver be assayed at Goldsmiths' Hall and there approved for standard, by striking thereon the lion and leopard's head crowned, or one of them, before they be exposed to sale. And hereof all persons concerned are required to take notice, and demean themselves accordingly: otherwise the Wardens resolve to make it their care to procure them to be proceeded against according to law. And will reward every person for ther pains in discovering before them (in court) the matter of fact of any transgressor (in the premises) upon the conviction of the offender.

A.D. 1697. 8 \& 9 William III. c. 8, s. 1. Enacts that any persons that shall bring any sort of wrought plate, between the 1st January, 1696, and the 4th November, 1697, into any of his Majesty's mints, \&c., shall be paid $5 s .4 \%$. per ounce for the same ; and that the master and worker of the mints shall receive all such 
wrought plate, which shall plainly appear to have thereon the mark commonly used at the Hall, belonging to the Company of Goldsmiths in London, besides the workman's mark, as sterling silver, without tarrying till it be melted and assayed. And where the wrought plate, so brought, shall not have the said marks thereon, then the party bringing such plate shall have the same forthwith melted and assayed, and shall be allowed 5s. 4d. per ounce for every ounce of sterling silver found therein.

A.D. 1697. $8 \& 9$ WILliam III. c. 8, s. 9. " And whereas it might reasonably be suspected that part of the silver coins of the realm had been, by persons regarding their own private gain more than the public good, molten and converted into vessels of silver or other manufactured plate, which crime had been the more easily perpetrated by them, in regard the goldsmiths or others, workers of plate, by the former laws and statutes of the realm, were not obliged to make their plate of finer silver than the sterling or standard ordained for the monies of the realm." It was therefore enacted that from and after the 25th day of March, 1697, no silver plate should be made of less fineness than that of $11 \mathrm{oz} .10 \mathrm{dwts}$. of fine silver in every pound troy, and that no silver vessels, \&c., made after that time, should be put to sale until such vessels, \&c., should be marked, except silver wire or such things as, in respect of their smallness, were incapable of receiving a mark. That the marks should be-that of the worker, to be expressed by the two first letters of his surname; the marks of the mystery or craft of the goldsmiths, which instead of the leopard's head and the lion, should be for this plate the figure of a lion's head erased,* and the figure of a woman, commonly called Britannia; and a distinct variable mark to be used by the Warden of the said mystery, to denote the year in which such plate was made; and that those marks should be affixed, on pain of forfeiture of all silver vessels, \&c., that should be exposed for sale.

As will be seen by the Tables, a mark was used by the Goldsmiths' Company in London to denote the year in which the plate was assayed long before this time. It would appear that no country office did now exist; and wrought plate not marked with body.

* Erased is a technical term in heraldry, signifying separate, or without the 
the Hall Mark of the Goldsmiths' Company of London was not to be received by the officers of the mints as sterling, but as uncertain silver.

A.D. 1698. 9 \& 10 William III. c. 28, recites, "That by an Act of the $7 \& 8$ William III. c. 19, no wrought plate can be shipped off, under the great penalties therein named, whereby no home wrought manufactured plate, though never so beneficial to the artificers and trade of this kingdom, is permitted to be exported ;" which was at that time a good and wholesome law, and tended to the benefit of the kingdom by keeping bullion at home to be coined: And that a great benefit may accrue to many artificers and to the kingdom in general, by giving liberty to export watches, sword hilts, wrought plate and several other manufactures, made within this kingdom, being of the fineness prescribed in the last recited Act. And enacts that after the 24th June, 1698, “ it shall be lawful to export such watches, plate, \&c., according to the rules prescribed in the said last recited Act, as shall be yearly allowed by the Commissioners of the Customs."

A.D. 1700. 12 William III. c. 43, s. $1 \& 2$. York, Exeter, Bristol, Chester, and Norwich, were appointed by this statute for assaying and making wrought plate; and in 1702, 1 Anne, Newcastle-upon-Tyne was added to the list. This Act requires that they shall stamp the silver plate assayed by them with the marks therein described; and in addition to the arms of their cities, and to the description of the variable mark to show the year when such plate was made, is added "or letter in Roman character." Nearly all these cities, it will be seen, were chosen for the same purpose as early as 2 Henry VI. A.D. 1424, but many had probably never availed themselves of the privilege, or had long since discontinued it, or it would have been unnecessary to reappoint them expressly by this statute.

As the King's subjects had, in the year 1697, sold most of their wrought plate to the mints to be coined into money, and the said Act 8 Will. III. c. 8, had abolished the old standard of $11 \mathrm{oz}$. $2 \mathrm{dwts}$. and established the new standard of $11 \mathrm{oz} .10 \mathrm{dwts}$. for wrought silver plate, and had intrusted only the said Company of Goldsmiths in London with assaying and marking all the new standard plate of the kingdom; and as a large demand now arose for wrought plate, and the goldsmiths in the remote parts of the kingdom were under great difficulties to supply their customers; 
therefore the goldsmiths, \&c., in the above cities (where mints were lately erected) obtained the above Act.*

YoRK was one of the most ancient places of assay, but it has several times discontinued its operations. It will be seen that in 1772, when a return was made to Parliament, the Assay Office was not in existence; but after that it appears to have recommenced. In 1848 we find it mentioned as an assay town, but doing very little business.

In NoRwich, plate was assayed and marked at an early period, and some specimens are existing among the Corporation plate of the date 1567. An annual letter seems to have been used, for on a silver gilt salt and cover, "The Gyfte of Peter Reade, Esquiar," to the Corporation, the marks are.-1. The Arms of Norwich, viz. gules, a castle surmounted with a tower argent, in base a lion passant gardant or; 2. A capital D; and 3. A cross-mound with a lozenge. It was therefore made and stamped at Norwich before 1568, for Peter Reade died in that year.

Among the records of the Corporation of Norwich we see that in 1614 the mark of a castle and lion was delivered by the Mayor and Corporation to the Wardens and Searcher of the trade of goldsmiths, and in July 1, 1702, Mr. Robert Harstonge was sworn assayer of gold and silver to the Company. Norwich has long since ceased to mark plate.

ExeTER.-There are no records at the Hall previous to 1701. The early marks used at Exeter previous to this date, are spoken of afterwards. The City hall mark was then a letter X crowned, subsequently altered to a castle of three towers. The Act passed in 1700, reappointing this city for assaying plate, did not come into operation until the 29th September, 1701. On the 7th August the Company of Goldsmiths met, and on the 17th of September, Wardens were appointed, and they resolved, with all convenient speed and safety, to put the Act in execution; and the first assayer was sworn-in before the Mayor on the 19th of November, 1701. The letters commenced with a Roman capital A for that year, as ordered by the statute, which characters, large and small,

* This Act only empowered the Goldsmiths' Company of London to stamp plate of the new standard, consequently the provincial offices were compelled to send plate to London to be assayed and stamped. The Act of 1700 conferred the same privilege upon the cities therein named, but from 1696 to 1701 no plate had been assayed or stamped anywhere but in London. 
they used throughout the alphabet until 1837, when they adopted old English capitals for that cycle. A Table of Letters for each year will be found further on. From 1797 the letters are the same for each year as the Goldswiths' Hall of London, they having reduced the number of letters to twenty instead of twenty-four in each cycle. The extensive collection of old English spoons in the possession of Dr. and Mrs. Ashford, of Torquay, especially rich in those manufactured at Exeter, has been of great service in verifying the table of date marks, and Dr. Ashford's careful investigation of the subject has greatly assisted our research.

Chester.-We have no record of the time when Chester first commenced assaying plate; it is not mentioned in the statute of the 2nd Henry IV. (A. D. 1423), but an office must have been established early in the 16th Century. An old minute book contains an entry some time prior to 1573, directing " That noe brother shall delevere noe plate by him wrought unles his touche be marked and set upon the same, before deliverie thereof upon paine of forfeture of everie diffalt to be levied out of his goods iijs iijd." We also quote the following, which may interest some of our readers :-

" Md the viij day of March in Anno $1603^{\circ}$ Yt is concluded and agreyed by the whole Compeney of the Gouldsmyihs $\mathrm{y}^{\mathrm{t}}$ this Order shalbe houlden and kept amongst us all, that the brood Arrowes agaynst Shrowstid * shall way everie one vj ${ }^{\mathrm{d}}$ stalling and everie on of the Compeny shall not sell vnder ix ${ }^{d}$ and for everie on that selles vnder $\mathrm{ix}^{\mathrm{d}}$ shall fforfyt xij ${ }^{\mathrm{d}}$ And $\mathrm{yt}$ is ffourther agreyed that the Steward for $\mathrm{y}^{\mathrm{t}}$ time shall come and sey them wayd and touchte. And to have fior his paynes ij a duzen. And for the perifiormance of thise order we have subscribed our names At that time beinge Alderman and Steward of $y^{\mathbf{e}}$ said Compeney of the Gouldsmyths."

Another entry of 1686 thus directs " And it is further concluded that the Wardens' marks shall be the coat and crest of the Citty of Chester on two punsons, with a letter for the year."

* This allusion to the "broad arrows against Shrovetide" refers to an ancient custom at Chester of holding shooting and running matches for prizes of silver broad arrows every Shrove Tuesday. These arrows (in sheaves of six in each) were given by the Shoemakers' Company, and by all newly-married couples, as homages to the Drapers' Company. 'The homage of the Sadlers' Company was a silver bell, to be given to the owner of the swiftest horse in a race on the same day. 
The arms of Chester, granted in 1580, are, party per pale, composed of the dexter half of the coat of England, gules, three lions passant gardant dimidiated, or, and the sinister half of the coat of Randle Meschine, Earl of Chester, azure, three garbs also dimidiated or. The crest is, on a wreath or, gules and azure, over a royal helmet, a sword of state erect, with the point upwards. Supporters; on the dexter side, a lion rampant or, ducally gorged argent; on the sinister side, a wolf argent, ducally gorged or. The early hall mark on plate was the coat here described, used as a stamp, down to about 1775 ; after which date a spurious coat of arms was adopted, of a dagger between three garbs, which is still used.

Again, 2 June, 1690, "And the same day the letter was changed from A to B and so to continue for one year."

These extracts prove that the Goldsmiths' Company at Chester assayed and stamped plate with the arms of the city, accompanied by a date letter and the maker's mark, long before 1701, but we have not met with any specimens to enable us to determine accurately the forms of the letters employed.

Chester was reappointed by the Act 12th William III (1700) and is regulated by that and the 12 th George II. The variable letter is changed on the 5th of August in every year.

We must here express our thanks to the present Assay Master, Mr. Jas. Foulkes Lowe, B.A., for his persevering kindness, not only in searching the records and furnishing extracts, but in obtaining impressions of ancient plate and affording much valuable information on the subject, which has enabled us to give a table of the assay letters used at Chester from 1689 to the present time. In this task he has been ably assisted by Mr. Thos. Hughes, F.S.A., the indefatigable Secretary of the Chester Archæological Society.

An interesting copper plate is preserved in the office, and is doubtless that mentioned in the cash book of Nov. 1692. "Paid $\mathrm{Mr}$. Bullen for a coper plate and punson $4^{\mathrm{s}}$." It contains principally the makers' marks, which in 1697 consisted of the two first letters of the surname, and on and after 1739 the initials of christian and surname. It has also the Roman capital date letters on square stamps used in the cycle commencing 1701, and those of other cycles, but not arranged in order. The other stamps are struck promiscuously on the plate, merely for the purpose of proving them.

At NewCastle-upon-Tyne the annual letter appears to have 
been used from 1702. Mr. Thomas Sewell, one of the Wardens of the Assay Office, has kindly furnished us with a table of date letters, chronologically arranged, compiled from the Assay Office books and the copper plate on which the maker strikes his initials, as well as from pieces of old plate which have from time to time come under his notice. From a careful examination of various examples of Newcastle plate, we have, in this edition, altered' some of the characters, making the table more complete. The change of letter takes place on the 3rd of May in each year.

Bristol did not avail itself of the powers conferred upon it by the statute of 1700 .

The author of 'The Touchstone for Gold and Silver Wares,' 1676, in speaking of the Act 2 Henry VI. says, "But what are the particular marks, the respective chief Governors of those seven places set on the silver works, I can give no account thereof. But this I can assert, that by reason the marks of those places are little known, they bear as little credit; and therefore the goldsmiths in those and other remote places, do frequently send up their silver works to receive the London touch."

A.D. 1719. 6 GEo. I. c. 11 , s. 1 , recites, that it is found by experience that the manufactures of silver, which were made according to the old standard, are more serviceable and durable than those which have been made of the new standard, therefore enacts, that the said old standard of silver plate made after the 1st June, 1720, shall be restored, revived and take place instead of the said new standard: and Sec. 2 enacts that no goldsmith, \&c., shall be obliged to make silver plate according to the said new standard.

Sec. 4 grants to his Majesty a duty of sixpence per ounce on all silver imported into and made in Great Britain.

Sec. 41 recites, that it may be requisite, for encouraging the several manufactures of wrought plate, to continue both the new and old standards, for the better accommodating the buyers of plate, and the workers and dealers therein : and therefore enacts that all wrought plate shall not be made less in fineness than $11 \mathrm{oz} .10 \mathrm{dwts}$. or $11 \mathrm{oz} .2$ dwts.; which two different standards of wrought plate shall be severally marked with distinguishing marks, viz.-plate of 11 oz. 10 dwts. with the workman's mark, the warden's mark, the lion's head erased and the Britannia; and plate of $11 \mathrm{oz} .2$ dwts. with the worker's mark, the warden's 
mark, a lion passant and a leopard's head; and that it shall not be lawful to make silver plate of a coarser allay.*

A.D. 1739. 12 GEo. II. c. 26. This Act recited the following statutes: 28 Edw. I., 2 Henry VI,, 18 Eliz., and 12 Will. III., and then enacted, that from and after the 28th May, 1739, all gold wares should not be less in fineness than 22 carats of fine gold, and all silver wares not less than $11 \mathrm{oz} .2 \mathrm{dwts}$. of fine silver, in every pound weight troy, but this was not to extend to jewellers' work, that is, to any gold or silver wherein any jewels or other stones should be set, or any other small works of that kind. The penalty $\mathfrak{E} 10$. for every offence. By the same Act it was ordered that the makers were to destroy their existing marks, which were the two first letters of their surname, and substitute the initials of their christian and surnames.

Sec. 5 enacts, That no person, making, trading or dealing in gold or silver wares shall sell, exchange, or expose to sale or export, until marked as follows-

Gold plate and old standard plate with the maker's mark, and these marks of the Company of Goldsmiths in London, viz. the leopard's head, the lion passant, and the yearly letter; or with the maker's mark and with the marks appointed to be used by the assayers of York and other places.

And new standard silver plate with the maker's mark, and these marks of the said Company, viz. the lion's head erased, the Britannia, and the yearly letter; or with the maker's mark, and the marks of one of the said cities or towns.

Sec. 11 of this Act states the great frauds in the trade, and particularly in using too much solder, and entrusts the Wardens, \&c., with determining what solder is necessary, and whether wrought plate is forward enough in workmanship, and has all the pieces affixed together or not.

A.D. 1756. StAT. 29 George II. c. 14, grants an annual duty to his Majesty, for all silver plate in Great Britain from 100 to 4000, of five shillings for every 100 ounces, from 5th July, 1756.

A.D. 1758. 31 GEORGE II. c. 32. An Act was passed to repeal the statute of the 6th of the King, by which a duty of sixpence had been imposed upon every ounce troy of silver plate imported

* None of the Country Assay Offices, nor their marks, are mentioned in this Act. 
into, or made in great Britain; and a duty of forty shillings for a licence, to be taken out by every person trading in, selling, or vending gold or silver plate, was granted in lieu of it; to take place from and after the 1si day of June, 1758, and the licence to be taken out annually, on forfeiture of twenty pounds for neglecting so to do. By the same Act, the stature of the 12th of the King, for the beiter preventing frauds and abuses in gold and silver wares, was likewise repealed, because the punishment which was enacted by it against counterfeiting stamps and marks upon gold and silver plate, was not suficiently severe to prevent that practice, and the said crime was now made felony, without benefit of clergy. This penalty was, in 1773, commuted to transportation for fourteen years.

A.D. 1759. Stat. 32 George II. c. 14, s. 1, exempts persons trading in gold not exceeding two pennyweights, or in silver not exceeding four pennyweights, in one piece of groods, from taking out a licence; and Sec. 3 grants an annual duty of $£ 5$. (instead of $4.0 s$.) to His Majesty, for every licence by each person trading in gold plate of two ounces or upwards, or in silver plate of thirty ounces or upwards.

A.D. 1773. 13 GEorge III. c. 52. This Act was passed for the appointment of wardens and assay masters for assaying and stamping wrought silver plate, in the towns of. Sheffield and Birmingham. Silver goods "shall be marked as followeth; that is to say, with the mark of the maker or worker thereof, which shall be the first letter of his christian and surname; and also with the lion passant, and with the mark of the Company within whose Assay Office such plate shall be assayed and marked, to denote the goodness thereof, and the place where the same was assayed and marked; and also with a distinct variable mark or letter, which letter or mark shall be annually changed upon the election of new wardens for each Company, to denote the year in which such plate is marked."

At Birmingham the selection of the variable letter, which is directed to be changed with the annual election of the wardens in July, is not confided to any officers, but the custom has been to take the letters in alphabetical order, adopting for one cycle of twenty-six years the Roman, and for another cycle the old English letters.

A.D. 1824. 5 George IV. Power was given to the Cornpany 
at Birmingham to assay gold as well as silver, and their marks are the same as London, except that the anchor is substituted for the leopard's head. The office has exclusive jurisdiction over all plate made in the town, or within thirty miles of it.

At Shefrield, silver only is assayed. Mr. J. Watson, the Assay Master, has most courteously furnished us with the variable letter for each year from the commencement in 1773, from references to the minute book wherein are recorded the meetings for the election of new wardens, as well as the letter to be used in the ensuing year; the change takes place on the 5th July. The plan adopted at Sheffield differs from all the other offices, for instead of taking the alphabet in regular succession, the special letter for each year is selected apparently at random until 1824, after which the letters follow in their proper order. Through Mr. Watson's kindness, we are enabled to lay before our readers a table of marks, which has been verified by him. The marks used at this office are the same as at London, except that the crown is substituted for the leopard's head, and variation of the date mark.

A.D. 1784. 24 George III. An Act was passed imposing an additional duty of eight shillings per ounce on gold plate, and sixpence per ounce on silver plate.* 'It was also enacted that the wardens or their assay masters should mark the pieces with a new mark, viz. the King's head, over and above the several other marks directed by law. The expression "The King's head" is understood to mean the representation of the head of the reigning Sovereign. The present mark is therefore the Queen's head.

A.D. 1798. 38 GEORGe III. An Act was passed to permit gold wares to be manufactured, for sale or exportation, of the standard of 18 carats of fine gold in every pound weight troy; such gold wares to be stamped with a crown and the figures 18 , instead of the mark of the lion passant, not to the exclusion of, but concurrently with the former standard of 22 carats.

A.D. 1854. 17 \& 18 Victoria. A Bill was passed allowing gold wares to be manufactured at a lower standard than before allowed by law, and to amend the law relating to the assaying of gold and silver wares. The first clause recites that Her Majesty

* The duty on gold was, in 1804 , increased to $16 s$., and in 1815 to $17 s$. per ounce. The duty on silver, in 1797, was 1 s.; in $1804,1 s .3 d$.; and in 1815 , 1s. $6 d$. per ounce; the payment being still denoted by the stamp of the Sovereign's head. 
may, by Order in Council, allow any standard for gold wares not less than one-third part in the whole of fine gold, to be marked with such mark or marks for distinguishing the actual fineness, to be declared in such order; and also to approve thereby of the instrument with which gold vessels, \&c., shall be marked or stamped, setting forth in figures the fineness according to the standard declared.

In pursuance of this Act, the following reduced standards were ordered by the Council, to be marked thus:- for 15 carat gold, 15 and 625 ; for 12 carat gold, 12 and 500 ; and for 9 carat gold, 9 and 375 .

The inferior qualities were not encouraged by the public, as is shown in the following extracts from the return dated 11th February, 1864, of the number and value of gold watch cases assayed and marked at each of the Assay Offices of the United Kingdom :-

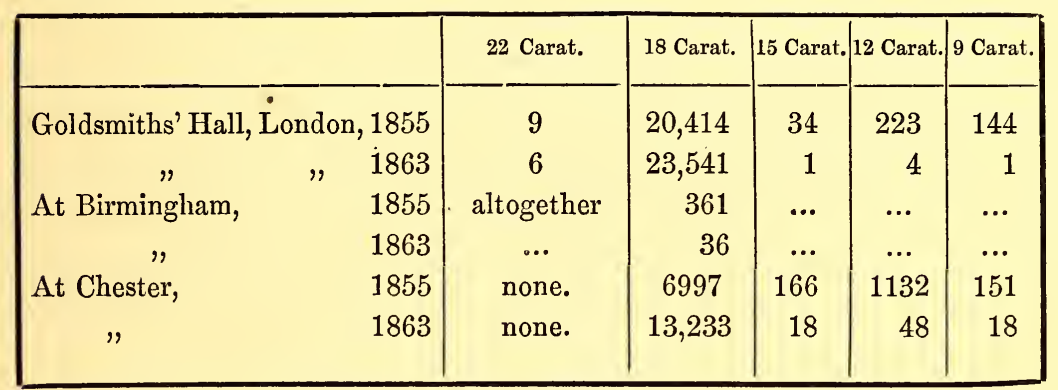

\section{EXTRACTS FROM THE REPORT OF THE COMMITTEE OF THE HOUSE OF COMMONS,}

APPOINTED TO ENQUIRE INTO THE MANNER OF CONDUCTING THE SEVERAL ASSAY OFFICES IN LONDON, YORK, EXETER, BRISTOL, CHESTER, NORWICH, AND

NEWCASTLE-UPON-TYNE.

[Ordered to be printed in 1773.]

The Report commences, that "In order to discover in what manner the several Assay Offices in London, Chester, Exeter and Newcastle-upon-Tyne (being the only Assay Offices which they find are now kept up in this Kingdom) have been conducted, ordered the Assay Masters to attend them, and produce an account of the number of Goldsmiths, Silversmiths and Plate Workers, \&c.-the names and places of abode of those now living that have entered their marks, also an account of the 
weight of all the gold and silver plate assayed and marked at each office for seven years last past."

From this it appears, that the offices at York, Bristol, and Norwich, were not then in operation.

As to the Goldsmiths' Hall, London, Mr. David Hennell, Deputy Warden, stated that there are at the said office two weighers, four drawers, and two assayers; and described what their duties were. Mr. Fendall Rushworth, Senior Assay Master; Mr. George Fair, Clerk to the Company; and Mr. Richard Collins, Fireman and Drawer, were also examined as to the annual diet tried on the 28th May, the modes of assay, \&c.

Mr. W. Hancock, a silversmith of Sheffield, said that his work had been injured by scraping; and he weni to the Hall and gave some drink to the assay master and scraper, since which time his plate has been less damaged. Mr. Spillsbury said that drawers or scrapers, if inclined, had opportunilies of delivering to the assayer better silver than they scrapo from the work; that the assayer had an opportunity of wrapping in lead what scrapings he pleased, to put upon the coppels which he delivered to the fireman; and as the standard mark is put upon the silver by the report of the assayer alone, he had opportunities of favouring any silversmith he pleased; that he had several times treated the workmen with drink; and thoughi ic of consequence to be on good terms with the scrapers, as they had the power of shewing favour; for when his plate had been objected to, he had known those difficulties removed by giving liquor at the Hall.

As to the office at Chester, Mr. John Scasebrick, the Assay Master, described the mode of operating: If pieces came, from which he could cut bits, he did so; if not, he scraped off sufficient for the assay and wrapped it in lead, and when the furnace and coppels were hot enough he refined the assay, but no flux was used, because the lead refined it. If it came out 11 oz. 2 dwts. fine silver, it was marked with the lion, the leopard's head, the city arms (being three lions and a wheatsheaf), and the letter for the year, the letter for the present official year (1772-3) being U. Sometimes it is passed at 11 oz., but then the owners are written to, to be more cautious for the future. He had no fixed salaryhis profit never amounted to $\mathfrak{1 0}$. in any one year; the diet was never sent to the Tower to be assayed. When asked how he knew when silver was sufficiently assayed, he answered, "We know by the assay: it first has a cap over it, then that works off 
in various colours; and after that it grows quite bright, and then we know all the lead is worked away."

Mr. Mathew Skinner, Assay Master at Exeter, described the mode of work. When asked to describe his method of assaying silver, he said, "I take a small quantity of silver from each piece, (the quantity allowed by Act of Parliament is eight grains from every pound troy weight) which I weigh by the assay pound weight; I wrap it up in a thin sheet of lead, and when the furnace is properly heated, the assays are put in and fired off; they are taken out when cool, and then weighed, and from the waste we ascertain its goodness. "That the standard for plate is 11 oz. 2 dwts. of fine silver and $18 \mathrm{dwts}$. of alloy, but they allow a remedy of $2 \mathrm{dwts}$. in the pound. That the marks he strikes upon wrought plate are the lion, the leopard's head, the Exeter mark (which is a castle), and the letter for the year; that the letter for the present official year (1772-3) is $Z$, in Roman character; that the letter is appointed annually, at the first hall meeting after the 7th Augusi, and goes through the whole alphabet; and that A will be the letter for next year."

Mr. Mathew Prior, Assay Master of the Goldsmiths' Company at Newcastle-upon-Tyne, described his mode of assaying: That of silver by fine lead; and his flux for gold was aquafortis, fine silver and lead. That he puts four marks upon the plate, viz. the lion, the leopard's head, the three castles, and the letter for the year; and that the letter for the present official year (1772-3) is $\mathrm{D}$.

Mr. David Hennell described a fraud which was sometimes attempted by dishonest workers, called a Convoy, to deceive the assayer. He said, "If scrapings or cuttings are taken from different pieces of the same sorts of plate, the whole mass so cut or scraped may prove standard, but several of these pieces may not be standard; and that it is common, to put good pieces in spoons, \&c., to the amount of 10,12 , or $15 \mathrm{dwts}$. above standard amongst the bad ones, as a kind of convoy for the rest; but if that is suspected, they separate it, and make different assays of all the parts, and if they find one part worse than standard they break the whole.

Another fraud spoken of by several witnesses was inserting iron, brass, \&c., in the handles of snuffers, tankards, sauce boats, \&c., which had escaped detection at Goldsmiths' Hall, and had been marked accordingly. 
An Appendix to this Report contains the names and places of abode of all the goldsmiths, silversmiths and plate workers now living, that have entered their marks in the Assay Office in Goldsmiths Hall, in the City of London, 8th March, 1773.

The names and trades of the present wardens and assayers of the Goldsmiths' Company, and when, at what times, and by whom they were respectively elected.

The oath taken by the Assayer at Goldsmiths' Hall.

The Appendix also contains an account of the prosecutions which have been commenced and carried on by the Company of Goldsmiths of the City of London, against any person or persons for frauds or abuses in gold or silver plate, within seven years last past :-

In 1767 William C., working silversmith, was prosecuted by indictment upon Stat. $28 \mathrm{Edw}$. I. and Stat. 6 George I. c. 11, for soldering bits of standard silver to tea tongs and shoe buckles which were worse than standard, and sending the same to the said Company's Assay Office, in order fraudulently to obtain their marks to the same.

In 1768 William K. of London, working silversmith, was prosecuted by indictment upon the said statutes, for making two salt cellars worse than standard, and selling them for standard.

In 1770 James M. E. and partners were severally prosecuted by actions on Stat. 12 George II. for making gold chains worse than standard; and Roger S. and others were prosecuted for selling gold watch chains worse than standard.

In 1778 John G. and William V., watchmakers were prosecuted for selling two silver watch cases without being marked, and which on that account were stopped at the Custom House in London, on their being found in a cask of hardware, in which action they suffered judgment to go by default.

The amount of. gold and silver plate assayed and marked at the Assay Offices for seven years, ending the 29th May now last past (1772).
LONDON Gold, 3926 lb. 2 oz. 8 dwts. 8 grs. " Silver, 692,528 lb. 3 oz. 11 dwts.
Chester 'Total, $715 \mathrm{lb}$. weight of Silver Plate.
EXeter Total, 2,800 lb. weight of Silver Plate.
NewCASTLE Total, 7,266 lb. weight of Silver Plate. 


\section{FRAUDS AND $\odot F F E N C E S$.}

$7 \& 8$ Victoria, c. 22, is the most recent statute, and which must now be taken as the guide and authority in all cases of forgery of the dies and marks used at the Assay Offices. It declares (Sec. 2) each of the following offences to be felony, and punishable with transportation or imprisonment.

The exact words of the statute are not here given.

Forging or counterfeiting any die used by any of the Companies of Goldsmiths or guardians for making gold or silver wares.

Marking wares with a forged die.

Counterfeiting marks of any die.

Transposing marks from one ware of gold or silver to another, or to a ware of base metal.

Having possession, without lawful excuse, and knowingly, of a forged die, or of any ware bearing the mark of a forged die, or a transposed mark.

Cutting off marks with intent to affix them to other wares.

Affixing to any ware a mark cut from another.

Fraudulently using genuine dies.

A case under this statute was tried before Lord Denman at Taunton Assizes in 1849. Two silversmiths were indicted for having in their possession a silver spoon having thereon a mark of a die used by the Goldsmiths' Company, which had been transposed from a silver skewer; and also a similar charge in respect to a silver soup ladle. The prosecution was instituted by the Goldsmiths' Company of London. The spoon and ladle were of modern make but bore the mark of the year 1774. An officer of the Goldsmiths' Company proved that on clearing off the gilding and using a blow pipe, he found that the spoon and ladle were not made in one piece, which would be the ordinary mode of manufacture, but that the parts bearing the marks were "inserted" or "brought on." A working silversmith proved that by direction of the prisoners he had made and sent to them two silver bowls for spoons; that they. were afterwards returned to him with handles attached to be gilt, and when he burnished them he perceived the old hall marks; that the bowls and stems or handles were generally made together. The defence was that the facts proved did not amount to a transposition, but were an 
addition, and as such were not a felony, but came under the 5th section of the Act which imposed a pecuniary penalty for the offence.

It was suggested that the spoon and ladle were made by using old silver skewers, with the old hall mark, for the stems, and adding to them bowls and figures at the top called "apostles" in order to give them the appearance of old plate, and that this was an addition. It was admitted by the prisoners' counsel to be a fraud in contravention of the Act, but not a felony under the 2 nd section. The jury found that it was not a transposition but an addition, and the prisoners were discharged; the judge remarked, however, "it appears to me very much to be questioned, at least, whether the description of transposition in the one section is not precisely the same as the description of addition in the other section.

\section{UNCERTAIN OLD ENGLISH HALL MARKS.}

It must be borne in mind that the Acts of Parliament relating to the stamping of plate at the Goldsmiths' Hall, London, only refer to the making and selling of plate in the cities of London and Westminster and the suburbs thereof. In the parts of England, therefore, distant from the metropolis, it was the custom, as enacted by 2 Rich. II. 1379, "that every goldsmith should have his own proper mark set upon his work," and also that " the work should bear the mark of the city or borough where it was assayed."

\section{EXETER.}

Mr. Morgan speaks of a mark he had occasionally met with on old plate, resembling the letter $\mathrm{X}$, surmounted by a crown, which he conjectured might be St. Andrew's cross, therefore of Scotch origin. We have met with several specimens, and on all, the mark is invariably the Roman letter $\mathrm{X}$, not a cross saltire or St. Andrew's cross.

Another peculiarity relating to this mark is, when it occurs on spoons, it is always placed within the bowl, in the same position as the leopard's head on spoons struck in London, it seems therefore probable that it denotes the stamp of a town. 
In order, therefore, that we may endeavour to trace this mark to its proper locality, we will briefly notice some of the specimens which have come under our notice, being all evidently of English manufacture.

A brown mottled stoneware jug, in silver gilt mounting, of the 16th Century, has the letter X crowned, the word EASTON, and a small old English date letter $\mathfrak{c}$ on a shield. The date engraved on the handle is 1586. W. Chaffers, Esq.

A brown stoneware jug, mounted in silver, has, 1st, the letter $\mathrm{X}$, surmounted by a crown and two pellets; $2 \mathrm{nd}$, the word ESTON; 3rd, C on a shield; 4th, a small old English date letter 15 on a shield. On the handle is engraved the date 1595 . W. Cozier, Esq.

A silver apostle spoon has three marks: 1st, the letter $\mathrm{X}$ crowned, and two fleurs-de-lis, within the bowl; 2 nd, the word EASTON; 3rd, a small old English date letter $\mathfrak{c}$ on a pointed shield. On the back are some letters pounced and the date 1634 . Dr. Ashford, Torquay. Forty-eight years before (or two cycles of 24 years), Easton put the same date letter on the jug above meníioned of 1586 .

These three pieces are from families in Devonshire, and we have traced several others to the same county. A silversmith residing in Exeter assures us that he has frequently met with similar marks, and has always considered them to be old Exeter stamps, in which opinion he is corroborated by other residents of the vicinity.

A silver spoon, bears an oblong stamp of a castle of three towers, with the word EXON (Exoniensis), EX on one side and $\mathrm{ON}$ on the other. It has on the handle the date 1692 pounced or pricked, but the make is probably earlier. Dr. J. B. Ashford.

Another spoon bears the impress of a castle and the word BAR, and the initials under I.P. The owner interprets it Barum or Barnstaple. It has the date of presentation pricked upon it, $170 \frac{1}{2}$, but it was doubtless made before the passing of the Act of 1700. Dr. J. B. Ashford.

A stoneware jug of the 16th Century, mounted in silver, bears the marks of the letter X crowned and the word YEDS. South Kensington Museum.

A silver apostle spoon has in the bowl, 1st, the letter X crowned; $2 \mathrm{nd}$, on the stem the name RADCLIFF; and 3rd, the letters I. R. 
and a flower; it also bears the pounced or pricked letters and date of presentation 1637. The Rev. T. Staniforth, Storrs, Windermere.

A brown stoneware jug of the 16th Century, mounted in silver handsomely chased, has the marks of an $\mathrm{X}$ crowned, with two pellets in the side angles and the word HORWOD stamped. In the possession of Mr. Martin Tucker Smith.

There are two silver apostle spoons marked with the letter $\mathrm{X}$ crowned, and a goldsmith's mark repeated thrice, with pounced letters and date 1659. In the Salford Museum, Peel Park.

A silver apostle spoon has the letter $\mathrm{X}$ crowned, as before, and a goldsmith's mark, and is pounced with letters and date of presentation 1635. Rev. T. Staniforth, Storrs, Windermere.

Dr. J. B. Ashford possesses several apostle spoons, with the crowned $\mathrm{X}$ inscribed with the following dates :-

1634 \& 1646. The crowned $\mathrm{X}$ has a small cross in each lateral angle, on a round shield.

1649. The crowned $\mathrm{X}$ has a triangular pellet in each lateral angle, ditto.

1660. The crowned $\mathrm{X}$ is on an escutcheon shaped to the letter.

1661. Crowned $\mathrm{X}$ on a round escutcheon

1675. Crowned $\mathrm{X}$ with round pellets in each lateral angle, on a round shield.

1678. Crowned X with two pellets and round beaded escutcheon. 1681. Crowned X with two pellets.

1682. Crowned $\mathrm{X}$ with two stars of 5 points at the sides and a small s under.

By reference to the dates of presentation on the pieces of plate here described, it will be observed they range from 1586 to 1700 ; and doubtless at Exeter most of the plate made in the West of England was sent to be stamped: indeed so much was an Assay Office required, that in the year 1700 Exeter was included in the statute, and after that date the shield of arms of the town (a castle with three towers) was adopted; and although Bristol was empowered to assay plate, both by 2 Henry VI. (1424), and also by 12 William III. (1700), it never availed itself of the powers thereby conferred. On the other hand, Exeter, before the Act came into operation, appointed its Wardens and Assayers with all convenient speed and safety, and they were sworn in on the 19th of November, 1701. 
Another old English mark occasionally found on plate previous to the year 1700 , is that of a half fleur-de-lis and a half rose conjoined, the latter being sometimes crowned.

A stoneware jug, mounted in silver, belonging to Mr. Addington, is ornamented with raised masks and scrolls and the royal arms of England as borne by Queen Elizabeth-a Tudor rose and inscribed date 1576, which from the style is evidently the date of its manufacture. The punched marks are the rose and fleur-de-lis conjoined. A Roman capital $\mathrm{R}$ and maker's name $\mathrm{CK}$.

A silver apostle spoon, belonging to the Rev. T. Staniforth, has a fleur-de-lis and a rose and crown conjoined; the old English letter $\mathfrak{T}$ and maker's mark T.H.

Another silver spoon, in the same collection, has a fleur-de-lis and rose and crown conjoined, a small black letter $k$ and a maker's mark. Both these are of the first half of the 17th century.

A silver spoon, with heart shaped end and flat stem, of the date 1680 to 1700 , has four marks : a double rose on a shield; a fleurde-lis in a pearled circle; a merchant's mark and RC, which is also of English make. This belongs to the Rev. T. Staniforth.

In the South Kensington Museum there is a silver mounted cocoa nut cup, with date of presentation 1576, which bears the stamps: 1st, a double rose crowned; $2 \mathrm{nd}$, a star of five points; and 3rd, a Roman capital R; of English work. A cocoa nut cup, mounted in silver, of the 16th century, in Messrs. Hunt and Roskell's possession, bears on the foot two stamps of the rose crowned, as on this specimen; round the rim it has the rose crowned and the Norwich arms of a castle and lion, with the letter $\mathrm{S}$ as date mark, and evidently made at Norwich.

\section{THE STANDARD.}

The English sterling, or silver standard, which term first occurs in the reign of Henry II., was of the fineness of $11 \mathrm{oz} .2$ dwts. in the pound troy, and $18 \mathrm{dwts}$. of alloy, and it has remained so, nearly without interruption, for more than 600 years, with the exception of a period of 20 years, from the latter end of the reign of Henry VIII. to the beginning of the reign of Elizabeth, when, at one time it was so debased that nine ounces of alloy were actually employed with only three ounces of silver. In the 
earliest accounts in which the standard of fineness is mentioned, it is always spoken of as the "old standard of England," or "esterling." The Saxon pennies were of the same standard.

In computing the standard of gold, it will be observed that the word carat is employed. This term is used by refiners, whereby they certify a certain composition of weights used in assaying and computing of standard gold, and this carat contains either the $24 \mathrm{th}$ part of a pound or the 24th part of an ounce troy.*

The standard of gold, when first introduced into the coinage, was of 24 carats, that is, pure gold, and from Henry III. to Edward III. remained so ; it was subsequently 23 carats $3 \frac{1}{2}$ grains fine, and half a grain only of alloy. The gold was debased by Heriry VIII. to 20 carats, but it was raised to 22 carats, which Charles II. made standard, and which still continues to be so for coins of the realm. In the reign of Edward IV., A.D. 1477, an Act was passed which ordained that, as the Act had been daily broken in the manufacture of gold wares, the fineness of gold should be fixed at 18 carats, but it was raised again to the standard.

One pound, or one ounce, of gold must contain 22 carats of fine gold, 1 carat of silver and 1 carat of fine copper, which together make 24 carats, or one pound or one ounce troy weight.

The marks for gold of 22 carats, and for silver of $11 \mathrm{oz} .2 \mathrm{dwts}$. were, up to the year 1844, the same, and hence a great facility was afforded to fraud, and, consequently, many instances occurred. An article of silver of the standard above named, being duly assayed and marked, 'had only to be gilt, and who, but those more skilled than ordinary purchasers, could say it was not gold?

This was changed by 7 and 8 Vict. c. rxii., which required that all wares of 22 carat gold should be marked with "a crown and the figures 22, instead of the mark of the lion passant."

A lower standard of gold was allowed by an Act, 38 Geo. III.,

* The carat is a bean, the fruit of an Abyssinian tree called Kuara ; this bean, from the time of its being gathered, varies very little in weight, and seems to have been a weight for gold in Africa. In India it is used as a weight for diamonds, as well as in Europe. It contains four grains.

In France the term denier was used to denote the fineness of silver, in the same manner as we use the word carat for gold; it indeed, agrees with the English ounce. The pound is divided into twelve parts, or deniers, and each denier or twelfth part into two oboles, or twenty-four grains. 
1798, which was marked with a crown and the figures 18, instead of the lion passant.

In 1854, 17 \& 18 VICTORIA, still lower qualities of gold wares were allowed to be made of 15, 12 and 9 carat pure gold in the 24: stamped with figures denoting the fineness, without the crown.

In the reign of Geo. III. the size of the leopard's head was diminished, and about 1823 it was deprived of its crown, and denuded of its mane and beard,-a great change from the bold front presented in the old punches,-and it has ever since looked more like a half-starved cat than a lion.

There are two standards for gold, and two for silver: the manufacturer may use either at his option, informing the authorities at the Assay Office which he has adopted in each parcel of goods sent to be assayed. The Standards for Gold are 22 and 18 carats of pure metal in every ounce, the ounce containing 24 carats; so that in each ounce there may be 2 or 6 carats, (one-twelfth or quarter of the weight) of alloy. The coinage of England is of the higher standard, 22 carats. The lower standard is used for all manufacturing purposes, except in the case of wedding rings, which are usually made of 22 carat gold. The Standards for Silver are 11 oz. 10 dwts. and 11 oz. 2 dwts. of pure metal in every pound troy. The higher standard is seldom or never used. The silver coinage is of the lower standard.

In the year 1697, it has been seen that there was an alteration in the standard of fineness, which was increased from 11 oz. 2 dwts. to $11 \mathrm{oz} .10 \mathrm{dwts}$. in the pound troy. This better standard was denoted by a change of stamps as follows :-1st. The marks of the workers to be expressed by the two first letters of their sur-names. 2. The mark of the mystery or craft of the goldsmith, which instead of the leopard's head, was to be a lion's head erased. 3. Instead of the lion, the figure of a woman, commonly called Britannia, was to be substituted; and, 4. A distinct variable mark to be used by the warden of the said mystery to denote the year in which such plate was made." Both these marks were used at first by the provincial Assay Offices, but the lion's head erased was omitted on silver of the new standard, at Sheffield and Birmingham.

On referring to the Minutes of the Goldsmiths' Company we find that, "On the 29th of May, 1695, new puncheons were 
received, the letter for the year being $t$ in an escutcheon." And on "the 27th March, 1697, the puncheons for the remaining part of this year (viz. up to the 30th May) were received, being, according to Act of Parliament, a lyon's head erased, a Britannia, and for the letter, the great court $A$ in an escutcheon."

Table shewing the variations of the Standard of Gold and Silver Currency, from the Year 1210.

Assay Weights :-Gold. 4 grains $=1$ carat ; 24 carats $=1$ pound or 1 ounce. Silver. $20 \mathrm{dwts} .=1$ ounce $; 12$ ounces $=1$ pound.

\begin{tabular}{|c|c|c|c|c|c|c|c|c|c|}
\hline \multirow{3}{*}{$\begin{array}{c}\text { A.D. } \\
1210\end{array}$} & \multirow[b]{2}{*}{ REIGN. } & \multicolumn{2}{|c|}{ GOLD. } & \multicolumn{2}{|c|}{ ALLOY. } & \multicolumn{2}{|c|}{ SILVER. } & \multicolumn{2}{|c|}{ ALLOY. } \\
\hline & & Carats. & Grs. & Carats. & Grs. & Ounces. & Dwts. & & Dwts. \\
\hline & 11 John ......... & & & & & 11 & 2 & 0 & 18 \\
\hline 1257 & 41 Henry III. ... & Fine & Gold. & nor & & 11 & 2 & 0 & 18 \\
\hline 1300 & 28 Edward I. ... & & & & & 11 & 2 & 0 & 18 \\
\hline 1344 & 18 Edward III... & 23 & $3 \frac{1}{2}$ & 0 & $0 \frac{1}{2}$ & 11 & 2 & 0 & 18 \\
\hline 1395 & 18 Richard II.... & 23 & $3 \frac{1}{2}$ & 0 & $0 \frac{1}{2}$ & 11 & 2 & 0 & 18 \\
\hline 1401 & 3 Henry IV. ... & 23 & $3 \frac{1}{2}$ & 0 & $0 \frac{1}{2}$ & 11 & 2 & 0 & 18 \\
\hline 1422 & 9 Henry V. & 23 & $3 \frac{1}{2}$ & 0 & $0 \frac{1}{2}$ & 11 & 2 & 0 & 18 \\
\hline 1422 & 1 Henry VI. ... & 23 & $3 \frac{1}{2}$ & 0 & $0 \frac{1}{2}$ & 11 & 2 & 0 & 18 \\
\hline 1465 & 4 Edward IV. ... & 23 & $3 \frac{1}{2}$ & 0 & $0 \frac{1}{2}$ & 11 & 2 & 0 & 18 \\
\hline 1483 & 1 Richard III. ... & 23 & $3 \frac{1}{2}$ & 0 & $0 \frac{1}{2}$ & 11 & 2 & 0 & 18 \\
\hline 1504 & 19 Henry VII.... & 23 & $3 \frac{1}{2}$ & 0 & $0 \frac{1}{2}$ & 11 & 2 & 0 & 18 \\
\hline 1531 & 23 Henry VIII... & 23 & $3 \frac{1}{2}$ & 0 & $0 \frac{1}{2}$ & 11 & 2 & 0 & 18 \\
\hline 1542 & $34, \quad, \quad \ldots$ & 23 & $0^{2}$ & 1 & $0^{2}$ & 10 & 0 & 2 & 0 \\
\hline 1544 & $\begin{array}{llll}36 & \prime & n\end{array}$ & 22 & 0 & 2 & 0 & 6 & 0 & 6 & 0 \\
\hline 1545 & $37, ", \quad \ldots$ & 20 & 0 & 4 & 0 & 4 & 0 & 8 & 0 \\
\hline 1548 & 2 Edward VI. ... & 20 & 0 & 4 & 0 & 4 & 0 & 8 & 0 \\
\hline 1549 & $3 \quad, \quad, \quad \ldots$ & 22 & 0 & 2 & 0 & 6 & 0 & 6 & 0 \\
\hline 1550 & $4 \quad " \quad, \quad \ldots$ & 23 & $3 \frac{1}{2}$ & 0 & $0 \frac{1}{2}$ & 3 & 0 & 9 & 0 \\
\hline 1551 & $5 \quad, \quad, \quad \ldots$ & .. & & & & 3 & 0 & 9 & 0 \\
\hline 1552 & 6 & 23 & $3 \frac{1}{2}$ & 0 & $0 \frac{1}{2}$ & 11 & 1 & 0 & 19 \\
\hline 1553 & Mary $\quad . . . . . . . . .$. & 23 & $3 \frac{1}{2}$ & 0 & $0 \frac{1}{2}$ & 11 & 1 & 0 & 19 \\
\hline 1559 & 1 Elizabeth ...... & 23 & $3 \frac{1}{2}$ & 0 & $0 \frac{1}{2}$ & 11 & 2 & 0 & 18 \\
\hline 1603 & 1 James I. ....... & 23 & $3 \frac{1}{2}$ & 0 & $0 \frac{1}{2}$ & 11 & 2 & 0 & 18 \\
\hline 1626 & 2 Charles I. ..... & 23 & $3 \frac{1}{2}$ & 0 & $0 \frac{1}{2}$ & 11 & 2 & 0 & 18 \\
\hline 1649 & 1 Commonwealth & 22 & 0 & 2 & $0^{2}$ & 11 & 2 & 0 & 18 \\
\hline 1660 & 12 Charles II. ... & 22 & 0 & 2 & 0 & 11 & 2 & 0 & 18 \\
\hline 1696 & 7 William III.... & 22 & 0 & 2 & 0 & 11 & 2 & 0 & 18 \\
\hline 1717 & 3 George I. ....... & 22 & 0 & 2 & 0 & 11 & 2 & 0 & 18 \\
\hline 1797 & 37 George III ... & 22 & 0 & 2 & 0 & 11 & 2 & 0 & 18 \\
\hline
\end{tabular}

Note.-The Anglo-Scotch Gold Coins are all of 22 carats fine and 2 alloy. 


\section{A S S A Y.}

Manufacturers of gold and silver are required to register their names and marks which indicate the same (usually their initials) at the Assay Office of their district, and all articles sent in by them to be assayed must be impressed with this maker's mark.

If they are then found to have been made in conformity with the appointed regulations, a small quantity, not exceeding 8 troy grains in the pound, is to be cut or scraped from them for trial of their purity, according to the standard for which they are required to be stamped. One moiety of the scrapings, or diet, as it is called, is to be reserved for the assay, and the other, if the purity prove to be correct, is to be put into that compartment of what is called the diet box which appertains to its standard. These diet boxes are proved once a year in the presence of a Lord of the Treasury, and of such wardens of the several Halls as the Government may think fit to appoint, except in the instances of Birmingham and Sheffield, whose diet boxes are proved at the Royal Mint.

The assay marks used at the Goldsmiths' Hall of London were ordered to be the letters of the alphabet, changing every year. We do not know with certainty when this plan was first adopted, but it was probably as early as the time when the Goldsmiths' Company were empowered to assay the precious metals, which according to their ordinances, was in the year 1300 . We can trace these letters back with a degree of certainty to the fifteenth century. This method of denoting the year in which any piece of plate was made and assayed, by placing upon it a letter of the alphabet, enables us at the present day to ascertain the date of its manufacture, if assayed at the Goldsmiths' Hall of London.

Different arrangements of the letters were adopted by the Corporations of other towns, who subsequently had the privilege of assaying granted them. The marks of the principal townsEdinburgh, Glasgow, Dublin, Exeter, Chester, Newcastle, Sheffield and Birmingham, we have succeeded in establishing, and they are given in a tabular form, through the kindness of the local authorities, who readily accorded leave to examine the records.

The Goldsmiths' Hall of London employ the lettrs A to U inclusive (omitting J.), forming a cycle of twenty years, the character of the alphabet being varied every succeeding cycle. 
These letters are changed on the 30th of May in every year, the office suspending business on the two days preceding, and the diet box being proved on the 29th. Each letter is therefore used during the moieties of two calendar years.

In a work published in 1678, entitled ' News from the Goldsmiths, or a Tryal of Gold and Silver Wares,' by W. T. Goldsmith, we are told that-

"There is a certain standard for gold and silver, according to which standard the coins of this Kingdom (both gold and silver) are made: and as good as that standard, all plate and small wares in gold and silver is to be made, and that there may be no defraud used by making any gold and silver work worse than the standard, there is a very easy and sure way appointed by law for the regulating those wares, the understanding of which may be of signal benefit to all who buy and wear any sorts of gold and silver wares whatsoever.

"As to London and the places adjacent, the Company of Goldsmiths hath the oversight of those wares, and the tryal of them committed to them; and therefore three days in the week, there is tryal made of any workman's wares (whose name and mark is inrouled in their Assay Office) and whatsoever works they try and find standard, is marked with these marks following: First, the workman's mark who made the wares (which is usually the two first letters of his christian and surname, and every workman's mark differs from others; the second is a leopard's head crowned, the third is a lyon, the fourth is a single letter (the letter which is used this present year being $\mathbb{T Z}$, 1677-8); and whatsoever plate or small wares have these marks on them, it is not to be questioned but that it is sterling or standard, that is as good as money.

"But there being several sorts of small wares, both in gold and silver, which cannot be assayed and marked at Goldsmiths' Hall, after it is finished: it is therefore sold with the private workman's mark; and to prevent defrauds in this, all workers in gold and silver, in London and its suburbs, are required by law to make known their marks, to the wardens of the Company of Goldsmiths, at their Hall in Foster Lane, that one workman may not strike a mark that is like another workman's; and that any persons which have wares marked with the workman's mark only, may, by addressing themselves to the Company of Goldsmiths, find out 
the makers of their wares; and if the wares which they have marked, be found worse than standard, the Company of Goldsmiths will procure the aggrieved party recompence and punish the workman.

"The reader cannot but be satisfied of the excellency of this way of warranting silver; but I shall shew you how it's neglected to the publick's great wrong. Although the wardens have power to search any goldsmith's shops and houses, and carry away any works which they shall make choice to try them, whether they be standard or not, and to fine the owners if they find them worse than standard; yet the workers and sellers of gold and silver wares being so numerous and dispersed in their dwellings to all parts of the City and suburbs, it is not easie that all their small wares can be found out, by the wardens of the Company to be tryed; they being sold therefore upon the bare workman's or shopkeeper's credit, and they having the marking of these wares themselves; there are these evils that do follow it.

" 1 . Some of their wares are not marked at all, though they may very well bear marking (whereby they are forfeited, though they be standard).

" 2. Some of their wares are marked with private marks, which are not inroulled at Goldsmiths' Hall : For some of them who have a mark inroulled at Goldsmiths' Hall will have another mark not inroulled; which mark they will set upon adulterated wares; and this counterfeit mark shall be so like the inroulled mark, that it will not be known to be the unlawful mark by any that doth not know what marks are inroulled and what are not; for there is only this difference; as if $\underset{\mathbf{B}}{\mathbf{P}}$ one over the other, is the mark inroulled at Goldsmiths' Hall, then " Р.в." (one by the other) may be the counterfeit mark; or if " $s$. " be the inroulled mark, then "I.S." may be the counterfeit, or any other way, according to the workman's device," \&c.

The following extract from the 'Touchstone for Gold and Silver Wares' will show what marks were in use in 1677, and the views of the writer, himself a goldsmith, on the subject of marks :-

"The Company of Goldsmiths have caused to be made (according to the aforesaid statutes and their Charter) puncheons of steel and marks at the end of them, both great and small, of these several sorts following, that is, the leopard's head crowned, the lyon; and a letter, which letter is changed alphabetically every year; the reason of changing thereof is (as I conceive) for that by the 
aforesaid recited statutes it is provided, That if any silver work that is worse than sterling be marked with the Company's mark, the Wardens and Corporation for the time being shall make recompense to the party grieved, so that if any such default should happen, they can tell by the letter on the work in what year it was assayed and marked, and thereby know which of their own officers deceived them, and from them obtain a recompense. These marks are every year made new for the use of the new wardens; and although the assaying is referred to the Assay Master, yet the Touch Wardens look to the striking the marks.

"They have also made in a part of their Hall a place called by them the Assay Office, wherein is a sworn weigher. His duty is to weigh all silver work into the office, and enter the same into a book kept for that purpose, and also to weigh it out again to the owner; only four grains out of every twelve ounces that is marked, is, according to their ancient custom, to be retained and kept for a re-assaying once in every year, before the Lords of the Council, in the Star Chamber at Westminster, and before a jury of twenty-four able Goldsmiths, all the silver works they have passed for good, the year foregoing.

"In this office is kept for publick view a Table or Tables, artificially made in columns, that is to say, one column of hardened lead, another of parchment or velom, and several of the same sorts. In the lead columns are struck or entred the workers marks (which are generally the first two letters of their christian and surnames), and right against them in the parchment columns are writ and entred the owners names, according to the intent of the words in the Statute (2 Henry VI. 14), to wit, 'And that the sign of every Goldsmith be known to the Wardens of the Craft,' which said warden's duty is to see that the marks be plain and of a fit size, and not one like another, and to require the thus entering the said marks, and also the setting them clear and visible on all gold and silver work, not only on every work, but also on every part thereof that is wrought apart, and afterwards soldered and made fast thereto, in finishing the same."

The same work gives an engraving of the marks used by the Goldsmiths' Company for the year 1676, viz. The Leopard's Head crowned, the Lion passant, and the Old English Letter T of a peculiar form, being somewhat like an $\mathrm{L}$, but evidently intended for the former, as the same is used at the head of each page in the word "Touchstone." 
The letter is enclosed in a pointed shield. (See Cycle 12.)

Hence we observe that tables were kept in public view in the Assay Office of the stamps of all the gold and silver plate makers; their signs being struck or punched on a strip of hardened lead, their names being written at length on parchment columns immediately opposite, and this plan of striking the signs appears to have been adopted and continued since 1423. Unfortunately none of these tables have been preserved : but one very interesting relic of the custom is in existence, namely, a large sheet of copper closely stamped with makers' signs only, of large and small sizes, but nothing is known of the names of the workers who used them.

The size of this copper plate is 24 by 18 in., and the inscription on a tablet underneath, is as follows:-

"On the above PLATE are the MARKS from WORKMEN taken at this OFFICE Prior to the Fifteenth of April A.D. I697 of which not any other Entry is to be found."

With the permission, kindly given by the Master, Wardens, and Court of Assistants of the Goldsmiths' Company, we are enabled to give, as a frontispiece to this work, a copy of this important tablet. It will be remembered that 1697 was the date of the Act of Parliament ordering the new standard of $11 \mathrm{oz} .10 \mathrm{dwts}$, and altering the marks from the lion and leopard's head to a figure of Britannia and the lion's head erased, and that the maker's marks were ordered to be the two first letters of their surnames. Before that period, the mark or sign of the workman was left to his own fancy, using a device or monogram of his own choice; and that the sign of every goldsmith should be known to the Wardens of the craft-it was struck upon a copper plate which hung in the Assay Office. By a comparison of the maker's marks on the plate with pieces of silver bearing corresponding stamps and the letter denoting the year, we may safely assume that it was first used in 1675 , the date of the Goldsmiths' Order (see p. 12), and is the identical table therein referred to, for the plate-workers to strike their marks upon.

From the 15th of April, 1697, the stamps were placed against the makers' names and date of entry; and these records are fairly preserved in volumes, bound in parchment, in the Goldsmiths' Hall, London. 


\section{THE D U T Y.}

A.D. 1719. 6 GEO. I. A duty of sixpence per ounce troy was imposed on all silver plate which should be imported or made in Great Britain.

A.D. 1758. 31 GEO. II. c. 32. The former Act was repealed, and in lieu thereof a duty of forty shillings substituted, to be taken out by every person trading in, selling, or vending gold or silver plate, and the licence to be renewed annually.

A.D. 1759. 32 GEo. II. c. 14. The licence was increased to $\mathfrak{2 5}$. per annum for every person trading in gold plate of two ounces, and silver of thirty ounces and upwards; persons dealing in gold and silver, of less weight than two pennyweights of gold, or in silver not exceeding five pennyweights, in one piece of goods, exempted.

A.D. 1784. 24 GEorge III. The annual licence of five pounds continued, and a duty of sixpence per ounce was again charged on all manufactured silver, the payment of which (as well as the subsequent increased duties) was and is still indicated by a stamp of the reigning sovereign's head on an oval shield.

Between the passing of this Act on the 25th of March, and St. Dunstan's day following (the 30th of May), when the new dies for the ensuing year were adopted, the duty stamp of the king's head, indented or incuse was used, but only for this short period.

A.D. 1797. 37 GEorge III. c. 90 . By this Act the duty on gold was placed at eight shillings per ounce, and silver at one shilling.

A.D. 1803. $43 \mathrm{G}_{\mathrm{EORGE}}$ III. c. 69 . The former Act of 24 Geo. III. as regards the licence, was repealed, and new licences appointed, viz.-For trading in gold more that two pennyweights and under two ounces, and in silver over five pennyweights and under thirty ounces, 22 . 6s. per annum; for trading in gold of two ounces in weight and upwards, and in silver of thirty ounces and upwards, $\mathfrak{E} 5.15 \mathrm{~s}$. per annum.

A.D. 1804. 44 GEORGE III. c. 98. The duty was increased, on gold to sixteen shillings per ounce, and silver one shilling and three pence per ounce.

A.D. 1815. 55 George III. c. 185. By this Act the duties were raised, on gold to seventeen shillings per ounce, on silver to eighteen pence per ounce (calculated, not on the gross weight of 
the articles, but on five-sixths of that weight, one-sixth being allowed for waste in finishing), at which they still remain, watch cases being exempt from duty by 38 Geo. III., c. 24 .

Upon the exportation of plate (except gold rings and wares under two ounces) a drawback of the whole duty is allowed, if the plate be new and has never been used.

\section{Gold and Silver Articles exempt from Control of Assay Offices.}

Gold Articles (12 Geo. II. c. 26).-Jewellers' work, wherein any jewels are set (other than mourning rings), rings, collets for rings or other jewels, chains, necklace beads, lockets, buttons, hollow or raised, sleeve buttons, thimbles, coral sockets and bells, ferrils, pipe lighters, cranes for bottles, small book clasps, stock or garter clasps jointed, very small nutmeg graters, snuff-box rims, whereof the tops or bottoms are made of shell or stone, sliding pencils, toothpick cases, tweezer cases, pencil cases, needle cases, filligree work; tippings or swages on stone or ivory cases; mounts, screws or stoppers to stone or glass bottles; ornaments, small or slight, put to amber or other eggs or urns; seals wrought, seals in cornelian, or other stones set therein. Any manufacture of gold or silver so richly engraved, carved or chased, or set with jewels, as not to admit of an assay to be taken of, or a mark to be struck thereon, without damaging, prejudicing, or defacing the same. Things which by reason of their smallness or thinness are not capable of receiving the marks, and not weighing $10 \mathrm{dwts}$. of gold or silver each.

1790 Silver Articles (30 Geo. III. c. 31).-Chains, necklace beads, lockets, filligree work, shirt buckles, brooches, stamped medals, spouts to china, stone, and earthenware teapots. The foregoing may be of any weight:-Tippings, swages, or mounts weighing not more than $10 \mathrm{dwts}$. of silver each, except necks and collars for castors, cruets, or glasses appertaining to any sort of stands or frames.

All silver wares not weighing $5 \mathrm{dwts}$. of silver each are exempt, except necks, collars and tops for castors; cruets or glasses appertaining to any sort of stands or frames; buttons for wearing apparel; solid sleeve buttons; solid studs not having a bevelled edge soldered thereon; wrought seals; blank 
seals, bottle tickets; shoe clasps; patch boxes; salt spoons, salt shovels, salt ladles; tea spoons, tea strainers; caddy ladles; buckles (shirt buckles or brooches before mentioned excepted); pieces to garnish cabinets, or knife cases, or tea chests, or bridles, or stands, or frames.

NoтE.-All these articles are excepted, and are liable to be assayed ; and all articles liable to be assayed, except watch cases, are chargeable with duty.

For the sake of comparison, and to show the amount of business done at the different Assay Offices, a table is here given, taken from a return made to Parliament in March, 1848, of the amount in gold and silver plate, in ounces, stamped at the several Goldsmiths' Halls in the United Kingdom in each of the last five years, with the amount of duty paid. The statement for the year 1847 only is as follows :-

\begin{tabular}{|c|c|c|c|c|c|}
\hline GoLDSMITHS' HALLS. & $\begin{array}{c}\text { GoLD. } \\
\text { 17s. per ounce. }\end{array}$ & $\begin{array}{c}\text { SILVER. } \\
\text { 1s. 6d.per ounce. }\end{array}$ & \multicolumn{3}{|c|}{$\begin{array}{l}\text { Gross DUTY oN } \\
\text { AMOUNT STAMPED. }\end{array}$} \\
\hline 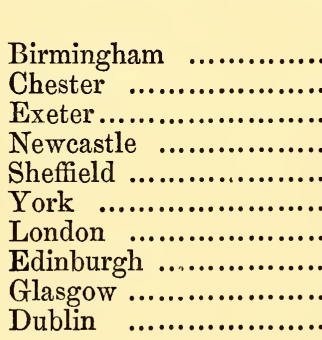 & $\begin{array}{r}\text { Ounces. } \\
2,276 \\
221 \\
294 \\
203 \\
\text { Nil. } \\
78 \\
5,196 \\
62 \\
5 \\
70\end{array}$ & $\begin{array}{r}\text { Ounces. } \\
42,985 \\
379 \\
41,597 \\
12,382 \\
54,012 \\
1,651 \\
983,250 \\
28,729 \\
23,751 \\
20,398\end{array}$ & \begin{tabular}{r}
\multicolumn{1}{c}{$£$} \\
5,158 \\
216 \\
3,369 \\
1,101 \\
4,050 \\
190 \\
78,160 \\
2,207 \\
1,786 \\
1,324
\end{tabular} & $\begin{array}{r}8 . \\
9 \\
17 \\
18 \\
12 \\
18 \\
5 \\
17 \\
18 \\
2 \\
16\end{array}$ & $\begin{array}{r}d . \\
10 \\
3 \\
7 \\
9 \\
0 \\
0 \\
0 \\
11 \\
0 \\
11\end{array}$ \\
\hline Total.... & 8,405 & $1,209,134$ & 97,567 & 17 & 1 \\
\hline
\end{tabular}

\section{CHRONOLOGICAL TABLE OF MARKS.}

1300 (28 Edw. I). Leopard's head.

1336 (Ordinance of the Goldsmiths' Company). 1. Leopard's head crowned. 2. Owner's or goldsmith's mark. 3. Assayer's mark, or variable letter.

1379 (2 Rich. II). 1. Goldsmith's, “ his own proper mark." 2. "Mark of the city or borough." 3. Assayer's mark, " appointed by the King."

1424 (2 Henry VI). "Touch of the leopard's head," and "Mark or touch of the workman." 
1477 (16 Edw. IV). " "Leopard's head crowned," and " Mark of the worker."

1576 (18 Eliz). 1. "The goldsmith to set his mark thereon." 2. "Touch of the leopard's head crowned," and " marked by the wardens."

1597 (Minutes of Goldsmiths' Company). "Her Majesty's Lion," "Alphabetical mark approved," and " Leopard's head, limited by statute."

1675 (Goldsmith's order). "Lion," and "Leopard's head crowned or one of them."

1697 (8 \& 9 Will. III). New Standard of Silver. "Lion's head erased ; Figure of Britannia and the maker's mark, being the two first letters of his surname."

1700 (12 Will. III). York, Exeter, Bristol, Chester, and Norwich appointed to assay silver plate, and stamp it with the marks of the lion's head erased and Britannia, and, in addition to the marks of their cities, a variable mark or letter in Roman character.

1702 (1 Anne). Newcastle added to the other cities for assaying and stamping plate.

1719 (6 Geo. I). Old standard restored. The lion, leopard's head, maker's mark and date mark, but both standards were allowed by this Act simultaneously, varying the respective marks.

1739 (12 Geo. II). Goldsmith's mark, "the initials of his christian and surnames."

1773 (13 Geo. III). Birmingham and Sheffield appointed for assaying and stamping silver plate.

1784 (24 Geo. III). Duty mark of the King's head.

1798 (38 Geo. III). Standard of 18 carat gold marked with a crown and 18.

1824 (5 Geo. IV). Birmingham empowered to stamp gold.

1845 ( $7 \& 8$ Vict.). Gold of 22 carats to be stamped with a crown and 22 , instead of the lion passisant.

1854 (17 \& 18 Vict.). Reduced standards of gold to be stamped; $15 \div 625 ; 12 ; 5 ; 9: 375$, for gold of 15,12 , and 9 carats.

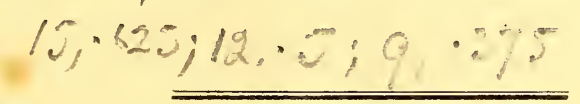




\section{ENGLAND.}

\section{$\longrightarrow$ \\ 1.-The Standard Marks.}

The first mention made of the lion passant is in the records of the Goldsmiths' Company, in May, 1597, where it is called "Her Majesty's lion ;" it is not referred to in any statute until 1675.

For gold of the old standard of 22 carats, and sterling silver of 11 oz. 2 dwts., the mark is a lion passant. Previous to 1845 there was no distinctive mark between standard gold and sterling silver.

For silver of the new standard of $11 \mathrm{oz} .10 \mathrm{dwts}$. the marks are a figure of Britannia and the lion's head erased, instead of the leopard's head and lion passant (8 Will. III. 1697).

For gold of 18 carats, a crown and the figures 18, instead of the lion passant (38 Geo. III. 1798).

For gold of 22 carats, a crown and the figures 22 , instead of the lion passant ( $7 \& 8$ Vict. 1845).

For gold manufactures a reduced standard (17 \& 18 Vict. 1854):

15 carats : 15 and $\cdot 625$ on separate stamps.

$12, \quad: 12$ and $\cdot 5$

$9,: 9$ and $375 \quad$,

The numerals on these punches are to express, decimally, the quantity of pure gold in the article so marked, thus : pure gold being 24 carats.

15 carats $\frac{15}{2}=\frac{5}{8}=625$ parts in 1000 .

$12 \% \frac{12}{24}=\frac{4}{8}=500 \quad$,

$2 \Rightarrow \quad \frac{9}{14}=\frac{3}{8}=375 \quad$ ",

Whe crown is zot tised on these lower standards.

\section{II.-The HaLL Marks.}

1. London. A leopard's head crowned (the ordinances of the Goldsmiths' Company of 1336, and subsequent Acts of Parliament).

2. York. Five lions on a cross. 
3. Exetrer. A castle with three towers.

4. Chester. Now, the mark is a sword between three garbs or wheatsheaves, but before 1779 the shield of the city arms was three demi-lions and a wheatisheaf on a shield.

5. Norwich. A castle and lion passant.

6. Newcastle. Three castles.

7. Sheffield. A crown.

8. Birmingham. An anchor.

\section{III.-DUTY MARK.}

The head in profile of the reigning sovereign.

1784. 24 Geo. III. This mark indicates the payment of the duty, and is impressed at the assay offices on every manufactured article of standard gold and silver, that is liable to the duty after payment to the officers of the Goldsmiths' Company, who are the appointed receivers.

\section{IV.-Date Mark.}

A letter of the alphabet. Each assay office has its peculiar alphabetical mark, indicating the year in which the plate was assayed and stamped; and therefore, plate that was stamped in any other place than London, had to be, when entered for drawback, accompanied by a certificate of the date from the office in which it was assayed and stamped.

In London the assay year commences on the 30th of May in each and every year, and the date marks are continued regularly with twenty letters of the alphabet, from $A$ to $U$ or $V$ inclusive (but always excepting the letters $\mathrm{J}, \mathrm{W}, \mathrm{X}, \mathrm{Y}, \mathrm{Z}$ ), which were used in succession.

\section{V.-The MaKer's Mark.}

Formerly this was some emblem, as a rose, a crown, a star, \&c., with or without the goldsmith's initials. These marks were ordered to be in 1363._" a mark of the goldsmith known by the surveyor." In 1379, "Every Goldsmith shall have his c:vn proper mark upon the work." In 1423, "The mark or sign of the worker." In 1675, the "Goldsmiths" order" enjoins that 
" the plate workers shall bring their marks to Goldsmiths' Hall, and there strike the same in a table kept in the Assay Office, and likewise enter their names and places of habitation in a book there kept for that purpose, whereby the persons and their marks may be known unto the wardens of the said company." (See plate.)

In 1697 (8 \& 9 Will. III.), the marks of the goldsmiths were to be expressed by the two first letters of their surnames.

1739. In 12 Geo. II. it was ordered that the makers were to destroy their existing marks, which were the two first letters of their surnames, and substitute the initials of their christian and surnames.*

\section{LONDON ASSAY OFFICE LETTERS.}

By the introduction in the annexed Table, of the shield used to enclose the letters in each cycle, much assistance is given in ascertaining the date of a piece of plate; but as several of the alphabets are somewhat alike, a few remarks are appended to each cycle to enable those who have not studied them sufficiently to tell at a glance the peculiar variations in each. Care must be taken in examining plate, to place the shield containing the date letter with its pointed base downwards, or some confusion may arise in mistaking $b$ for $\mathbf{q}, \mathbf{p}$ for $\mathrm{d}, \mathrm{n}$ for $\mathrm{u}$, \&c.

- It has been suggested that we should in this edition give the rames of the goldsmiths of London in the XVIth, XVIIth, \& XVIIIth centuries, that the initials of the makers found on ancient English plate might be referred to their rightful owners, but we hesitated for several reasons. One of the first considerations was that we have no record of the goldsmiths in London earlier than 1697, which is the earliest date in which they are registered in the company's books. In the second place, to give a catalogue of the names and places of abode of all the goldsmiths, silversmiths, and plate workers who have entered their names in the Assay Office in Goldsmiths Hall, London, since 1697, would fill volumes and be of very little service considering how few real artists of any eminence are to be found among them. To give some idea of the interminable nature of such a list, a reference to the report of the Horse of Commous, when an inquiry wras made into this subject in 174 (seo page 23) will show us that the plate workers, goldsmiths, spoon makers, haft and hilt makers and candlestick makers for that year were upwards of 500, without counting other small workers, such as the watch case makers, buckle makers, button makers, \&z. 
LONDON ASSAY OFFICE LETTERS.

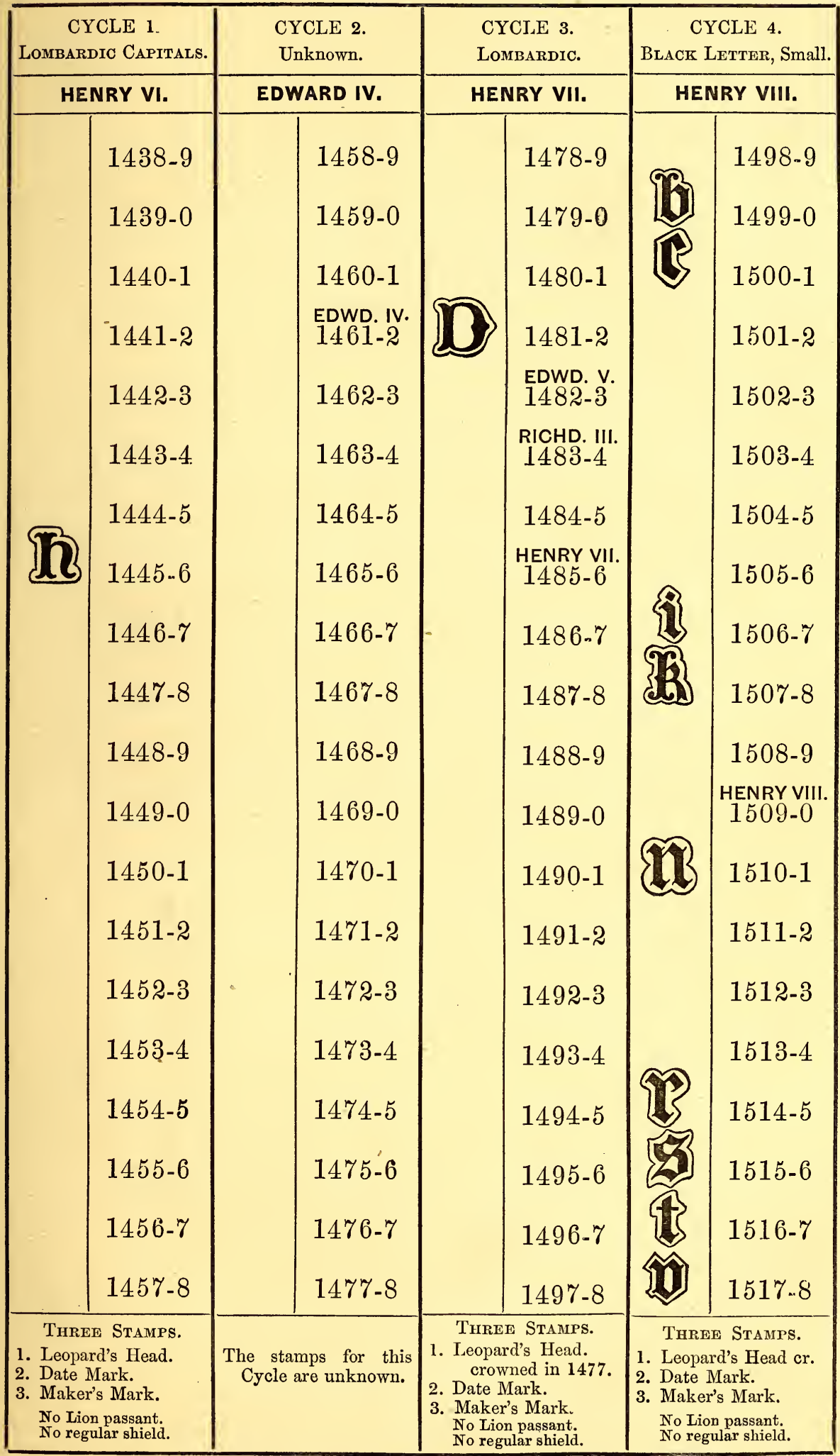




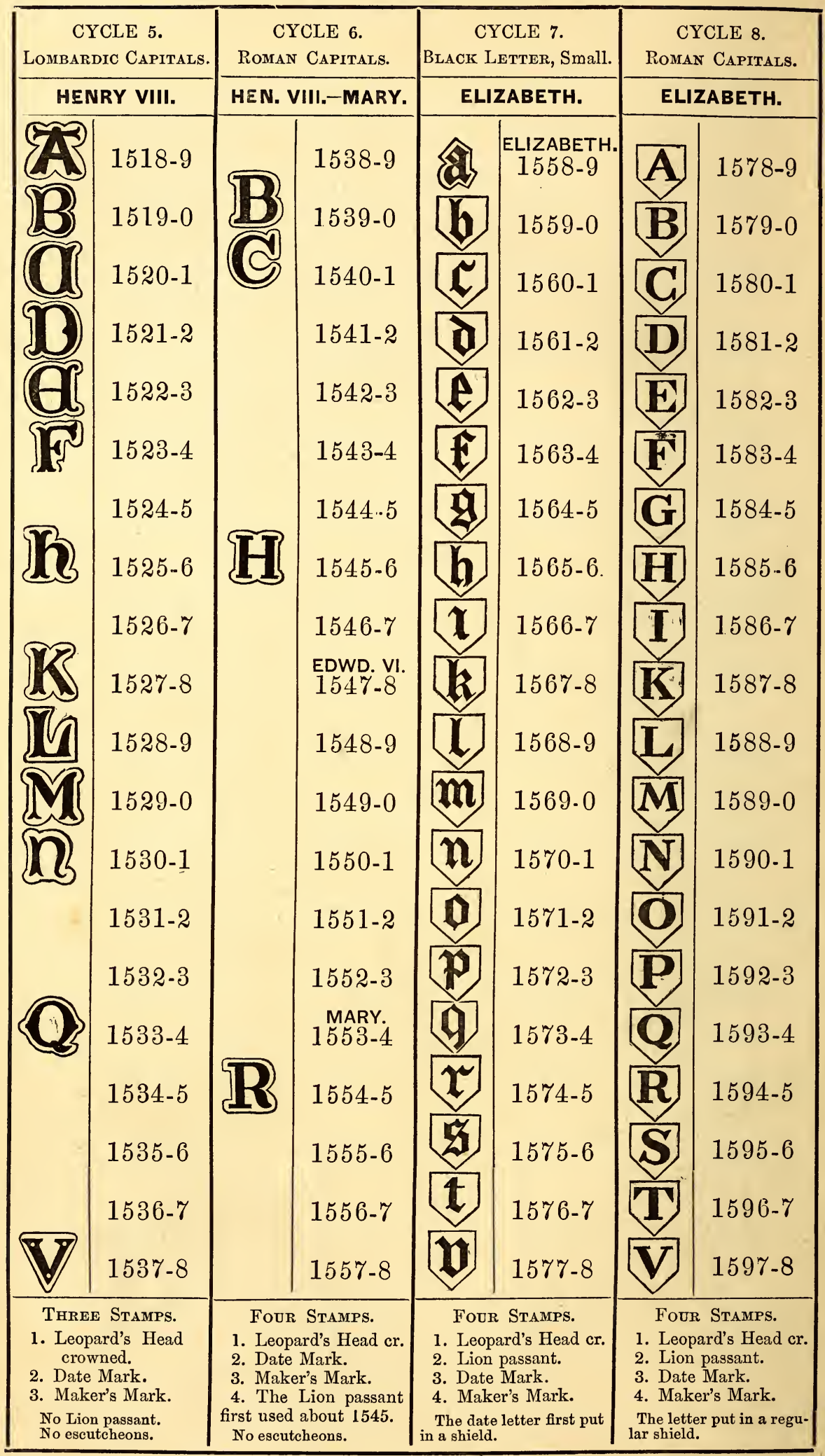




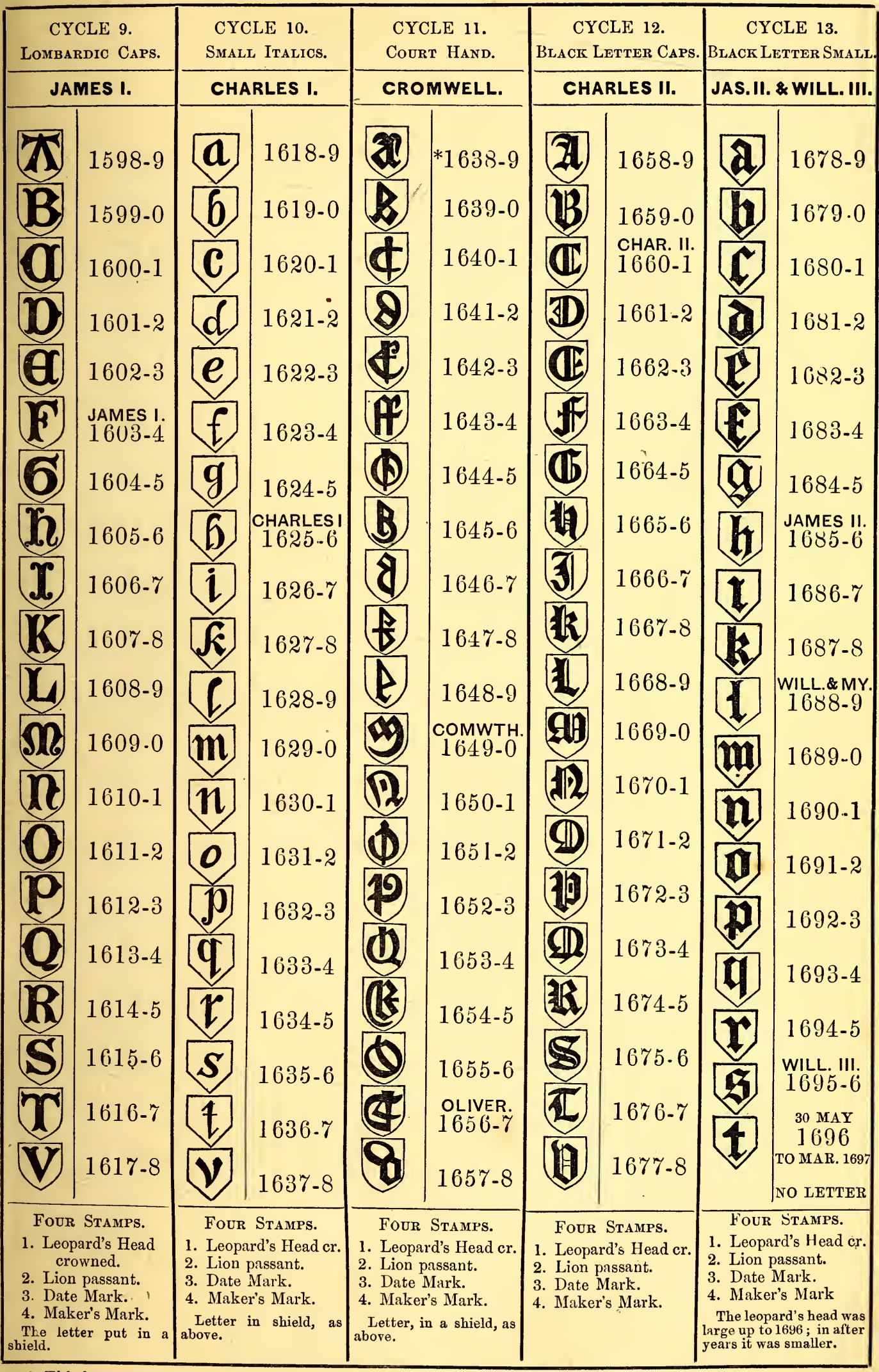

* This letter, towards the end of the official year, appears to have been injured, as here represented, but it is also seen quite perfect. 


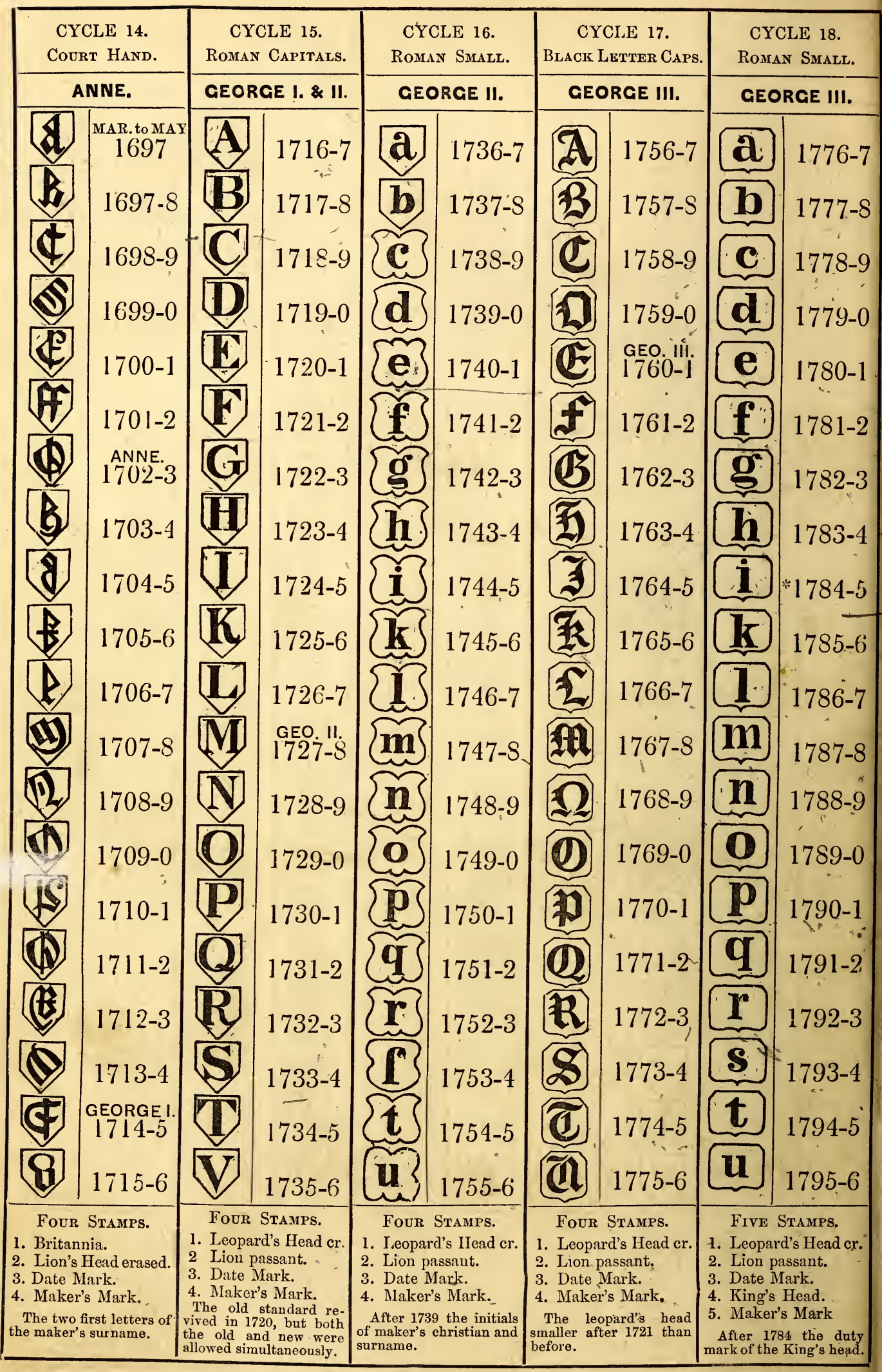

* Between the passing of this Act on the 25th March, 1784, and St. Dunstan's-day, (the 30th May following), when the new dies for the ensuing year were adopted; the King's head indented or incuse was used, but only for this short period. 


\begin{tabular}{|c|c|c|c|}
\hline \multirow{2}{*}{$\begin{array}{c}\text { CYCLE } 19 . \\
\text { RoMAN CAPITALS. }\end{array}$} & \multirow{2}{*}{$\begin{array}{c}\text { CYCLE } 20 . \\
\text { Roman SmaLl. } \\
\text { GEO. IV.-WILL. IV. }\end{array}$} & $\begin{array}{c}\text { CYCLE } 21 . \\
\text { BLACK LETTER CAPS. }\end{array}$ & $\begin{array}{c}\text { CYCLE } 22 . \\
\text { BLACK LETTER SMALL. }\end{array}$ \\
\hline & & VICTORIA. & VICTORIA. \\
\hline 1796-7 & 1816-7 & $1836-7$ & $1856-7$ \\
\hline $1797-8$ & $1817-8$ & $\begin{array}{c}\text { VICTORIA. } \\
1837-8\end{array}$ & $1857-8$ \\
\hline 1798-9.9 & $1818-9$ & $1838-9$ & $1858-9$ \\
\hline 1799-0 & $1819-0$ & 1839-0 & 1859-0 \\
\hline 1800-1 & $\begin{array}{c}\text { GEORGEIV } \\
1820-1\end{array}$ & ' 1840-1 & $1860-1$ \\
\hline $1801-2$ & 1821 -2 & 1841-2 & $1861-2$ \\
\hline $1802-3$ & 1822-3 & $1842-3$ & $1862-3$ \\
\hline $1803-4$ & $1823-4$ & 1843-4 & 1863-4 \\
\hline $1804-5$ & $1824-5$ & $1844-5$ & $1864-5$ \\
\hline $1805-6$ & $1825-6$ & $1845-6$ & $1865-6$ \\
\hline $1806-7$ & 1826-7 & $1846-7$ & $1866-7$ \\
\hline $1807-8$ & $1827-8$ & $1847-8$ & $1867-8$ \\
\hline 1808-9 & $1828-9$ & $1848-9$ & $1868-9$ \\
\hline . $1809-0$ & 1829-0 & 1849-0 & $1869-0$ \\
\hline $1810-1$ & $1830-1$ & $1850-1$ & $1870-1$ \\
\hline $1811-2$ & $1831-2$ & 1851-2 & $1871-2$ \\
\hline 1812-3 & $1832-3$ & $1852-3$ & $1872-3$ \\
\hline $1813-4$ & $1833-4$ & $1853-4$ & $1873-4$ \\
\hline $1814-5$ & $1834-5$ & $1854-5$ & $1874-5$ \\
\hline $1815-6$ & $1835-6$ & $1855-6$ & $1875-6$ \\
\hline $\begin{array}{l}\text { Five STAMPS. } \\
\text { 1. Leopard's Head } \\
\text { crowned. } \\
\text { 2. Lion passañt. } \\
\text { 3. Date Mark. } \\
\text { 4. Maker's Mark. } \\
\text { 5. King's Head. }\end{array}$ & $\begin{array}{l}\text { FIVE STAMPs. } \\
\text { 1. Leopard's Head. } \\
\text { 2. Lion.passant. } \\
\text { 3. Date Mark. } \\
\text { 4. Make's Mark. } \\
\text { 5. King's Head. } \\
\text { After 1823 the leopard's } \\
\text { head without a crown }\end{array}$ & $\begin{array}{l}\text { Five Stamps. } \\
\text { 1. Leopard's Head. } \\
\text { 2. Lion passant. } \\
\text { 3. Date Mark. } \\
\text { 4. Maker's Mark. } \\
\text { 5. Queen's Head. }\end{array}$ & $\begin{array}{l}\text { Five Stamps. } \\
\text { 1. Leopard's Head. } \\
\text { 2. Lion passant. } \\
\text { 3. Date Mark. } \\
\text { 4. Maker's Mark. } \\
\text { 5. Queen's Head. }\end{array}$ \\
\hline
\end{tabular}

Nore.-Large and small sized punches are used to suit the plate to be stamped; so that from 1756 to the present day, the large stamps bear the letter in a shield as here indicated,--the smaller ones have the letter in a square escutcheon, the base slightily convex but not pointed, aud the upper corners cut off. 


\section{CHRONOLOGICAL LIST OF ENGLISH PLATE.}

With few exceptions all these examples of English plate were exhibited at the Special Exhibition of Works of Art on Loan at the South Kensington Museum in 1862 ; when catalogueing that magnificent collection of plate the writer had an opportunity of verifying the foregoing table, not only as regards the assay or date letters, but also the forms of the escutcheons enclosing them, a great desideratum to those who consult the table, in determining the date of a piece of plate when the characters used in the cycles are similar.

The numbers which precede the references allude to their places in the catalogue of that collection, where they will be found fully described. Besides these, many other interesting and important specimens of English silversmiths' work were displayed on that occasion, but they could not be included in this list, from the fact of the marks having become illegible or altogether obliterated, so that their exact date could not be ascertained.

Crcle I.-May, 1438, to May, 1458.

Date. Catalogue No.

1445. H. 7767. The Grace Cup of St. Thomas-a-Becket, the cup and cover of ivory, mounted in silver gilt, inscribed "Vinum tuum bibe cum gaudio;" the ornamented borders are of a later period.-Philip H. Howard, Esq., of Corby.

1445. H. 7753. The Silver Spoon given by Henry VI. to Sir Ralph Pudsey in 1463, together with his boots and gloves, at Bolton Hall, after the battle of Hexham, now preserved at Hornby Castle, Lancashire.Capt. Pudsey Dawson.

Crche III.-May, 1478, to May, 1498.

1481. D. 3241a. Silver gilt Cup called the Anathema Cup, dated 1497, inscribed with the name of the donor, Langton Bishop of Winchester, and the sentence, "Qui alienaverit anathema sit."-Pembroke Coll., Camb. 
Date. Catalogue No.

1481. D. 5725. Silver gilt low Bowl, fluted stem, inscribed, "Benedictus Deus im Dona Suis ame," in Lombardic letters.-J. Dunn Gardner, Esq.

1487. K. Silver gilt Salt Cellar.-Christ's College, Cambridge.

1497. V. Two small Spoons, with slender stems.-Rev. T. Staniforth.

Cycle IV.-May, 1498, to May, 1518.

1499. b. 5455. Grace Cup and Cover ornamented with crossed bands, and in the panels are maidens' heads and flagons, the badges of the Company; on the cover a maiden seated with a unicorn, with blue enamel bands, \&c., presented by Sir Thomas Legh.Mercers' Company.

1500. r. An old English Spoon.-Painter Stainers' Company. 1506. i. Bishop Fox's Spoons, with owls at the ends of the handles.-Corpus Christi College, Oxon.

1507. k. 3223. Silver gilt Cup and Cover in form of a Tudor rose, battlemented, engraved with roses, portcullises and daisies (Marguerites), given by the foundress, Margaret, Countess of Richmond.-Christ's Coll., Cambridge.

1507. k. 3224. Pair of Silver gilt Salt Cellars, of hour-glass form, ornamented with Tudor roses, \&c.; presented by the Foundress, the Countess of Richmond.Christ's College, Cambridge.

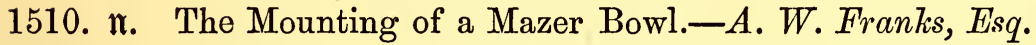

1515. \&. Apostle Spoon, with the maker's mark of an S.Dr. and Mrs. Ashford.

1515. \$. 3207. Silver gilt Tazza Cup and Cover, ornamented with stamped pattern of roses and fleurs de lis.Corpus Christi College, Oxford.

1516. t. Bishop Fox's Spoons, with balls at the ends of the stems.-Corpus Christi College, Oxford.

1516. t. 3237. Set of Thirteen silver gilt Apostle Spoons, given by Archbishop Parker to Corp. Christi Coll., Camb.

1517. b. Gothic silver Paten, parcel gilt, sunk centre; within a tressure of 6 arches is the head of our Saviour, a nimbus round his head and radiating borders, engraved and gilt.-Rev. T. Staniforth. 
CycLe. V.-May, 1518, to May, 1538.

Date. Catalogue No.

1518. A. 5448. Salt Cellar, of hour-glass form.-Ironmongers' Company.

1519. B. Set of Twelve Apostle Spoons, from the Bernal Collection.-Rev. T. Staniforth.

1520. C. Silver Cup. Christ's College, Cambridge.

1521. D. 5726. Old English Spoon, with fluted knob on the stem.-J. Rainey, Esq.

1522. E. 5448. Salt Cellar, of hour-glass form.-Ironmongers' Company.

1522. E. Spoon, with seal top, in the possession of Dr. and Mrs. Ashford, Torquay.

1523. F. 5402. Henry VIII.'s Cup, repoussé with scrolls, fleur de lis and rose, with bells on the bottom of the cup.-Barber Surgeons' Company.

1523. F. 5497. Cocoa Nut Cup, silver mounted. - Vintners' Company.

1525. H. 3239. Silver gilt Salver, given by Archbishop Parker in 1570.-Corpus Christi College, Cambridge.

1527. $\mathrm{K}$ Chalice and Paten, given by Henry VIII. to Sir Thomas Pope.-Trinity College, Oxford.

1528. L. Spoon, with statuette of St. Nicholas, and three children in a tub, of good early work; the stem is inscribed, SYNT $\cdot \mathrm{NYCOLAS} \cdot \mathrm{PRAY} \cdot \mathrm{FOR} \cdot \mathrm{WS}$. This spoon is supposed to have been formerly used in the Abbey of St. Nicholas, Abingdon.-J. Dunn Gardner, Esq.

1529. M. 3202. Mazer Bowl, silver gilt mounting.-All Souls' College, Oxford.

1530. N. Apostle Spoon.-Rev. T. Staniforth.

1533. Q. 3204. Silver gilt Cup and Cover, double handled and urn shaped, repoussé with scrolls._Christ's College, Oxford.

1537. V. Apostle Spoon, with dots on the date letter as shown on the table. $-D r$. and Mrs. Ashford.

CrcLe VI.-May, 1538, to May, 1558.

1539. B. Apostle Spoon.-Inn Holders' Company.

1540. C. 3229. Silver gilt Cup and Cover, the latter having a 
Date. Catalogue No.

boss of six pinnacles and a shield of arms on the top in translucent enamel._Christ's College, Camb.

1545. H. Spoon, with lion sejant on the end of the stem, the leopard's head crowned in the bowl, the lion passant on this piece is the earliest example we have met with.-Dr. Ashford, of Torquay.

1554. R. Sir Martin Bowes' Cup, presented (according to the Minutes) in 1561.-Goldsmiths' Company.

Cycle VII.-May, 1558, to May, 1578.

1558. a. Stone Jug, silver mounted, repoussé with scrolls, fruit, satyrs, and masks, the cover surmounted by St. George and the Drägon; on the handle a bifrons maiden's head and quaint head dress.-J. Dunn Gardner, Esq.

1560. c. 3236. Circular Salt and Cover, given by Archbishop Parker, of Canterbury, in 1570.-Corpus Christi College, Cambridge.

1560. ᄃ. Silver mounted Stoneware Jug.-R. Temple Frere, Esq.

1561. d. Apostle Spoon.-Inn Holders' Company.

1562. ฉ. 5500. Delft Tankard, silver mounted, given by David Gitting in 1563.-Vintuers' Company.

1563. f. 5505. A large Cup and Cover, engraved with subjects relating to the manufacture of wax, the gift of Richard Normansell.-Wax Chandlers' Company.

1564. a. 5412. A Square Salt, given by Roger Dunster in 1641. -Clothworkers' Company.

1566. f. 5727. Silver gilt Chalice.-J. P. Dexter, Esq.

1568. l. 3234. Cup and Cover, richly ornamented with masks, fruit and flowers, and female heads in relief, surmounted by a nude male figure; given by Archbishop Parker in 1569.-Corpus Christi College, Cambridge.

1569. m. 5728. Brown Stoneware Jug, silver mounted.-Maker I. R.-E. A. Sanford, Esq.

1569. m. 5729. Stoneware Jug, silver mounted.-J. Toovey, Esq. 1570. ․ 3235. Silver gilt Tankard, repoussé with arabesques, given by Archbishop Parker in 1571.-Corpus Christi College, Cambridge. 
Date. Catalogue No.

1570. n. Silver seal-top Spoon.-Dr. and Mrs. Ashford.

1571. o. 5730. Brown Stoneware Jug, silver mounted.-Maker N. S. interlaced.-J. P. Dexter, Esq.

1571. o. 5731. Chalice and Paten, with engraved belt. Dated 1576.-J. Dunn Gardner, Esq.

1572. p. 5733. Earthenware Jug, silver mounted.-H. Magniac, $E s q$.

1572. p. 3230. Silver gilt Tazza, with punched ornaments.Christ's College, Cambridge.

1573. q. 5734. Silver Tankard, engraved with strap work and medallions of female heads. Maker's mark, a crab, date c. 1580.-L. Huth, Esq.

1573. q. 5735. Chalice and Paten, with engraved belt of running pattern.-J. Rainey, Esq.

1574. r. 5738. Silver Tankard. Maker's initials C. L.-Ashmolean Museum, Oxford.

1574. r. Apostle Spoon.-Rev. T. Staniforth.

1574. r. 3237. Apostle Spoon, with St. Paul.-Corpus Christi College, Cambridge.

1575. \$. 3237. Twelve Apostle Spoons._Corpus Christi College, Cambridge.

1576. t. 5739. Silver Chalice and Paten.-J. Rainey, Esq.

1576. t. 5423. Simon Gibbons' square Salt.-Goldsmiths' Company.

1577. b. 5741. Stoneware Jug, silver mounted. Maker's initials C. C.-J. D. Gardner, Esq.

Crcle VIII.-May, 1578, to May, 1598.

1578. A. Gilt Apostle Spoon, inscribed “ A H Nata Año Dñi 1578. Octob. 10. Inter Hor. 12 et Pri. in Aurora Susceptore Gual. Moyse."-Rev. T. Staniforth.

1578. A. 574.2. Silver gilt Tankard, repoussé with fruit and flowers, on the purchase is a mermaid. Maker's initials E. S.-Baron Lionel de Rothschild.

1578. A. 5743. Bell-shaped Cup and Cover, engraved with scrolls and raised masks.-W. Cozier, Es' .

1579. B. 5744. Silver gilt Tazza, chased with cartouches and repoussé helmeted head. Maker H. C. a hammer and vice.-H.R.H. the Duke of Camlridge. 
Date. Catalogue No.

1579. B. 5745. Silver Cup, in form of a " Pelican in her piety." The stem ornamented with masks and scrolls, the foot with hunting scenes. Maker's mark a bird. -Sir Stephen Glynne, Bart.

1580. C. Antique Spoon, with terminal female bust.-Dr. and Mrs. Ashford.

1580. C. 5748. Silver gilt Cup and Cover. Maker's mark H. C. a hammer and vice.--L. Huth, Esq.

1581. D. 5746. Silver gilt Ewer and Salver, beautifully chased, set with oriental agates. One of the finest examples of English plate known. Maker's mark a trefoil.The Duke of Rutland.

1581. D. 5750. Stoneware Jug, silver mounted.-L. Huth, Esq. 1582. E. Spoon with baluster knob.-Rev. T. Staniforth.

1583. F. 5751. Square Salt Cellar.-Baron Lionel de Rothschild. 1584. G. 5752. Mounted Stoneware Jug. Maker's mark B. a pellet in each space.-A. W. Franks, Esq.

1585. H. 5753. Porcelain Vase, silver mounted. Maker's mark three trefoil leaves.-H. Farrer, Esq.

1588. L. 5754, Ostrich Egg Cup. Maker's mark a flower.Earl of Home.

1589. M. Silver Chalice.-Messrs. Garrard.

1589. M. Apostle Spoon.-Rev. T. Staniforth.

1590. N. 5465. Rose-water Dish, chased with dolphins and flowers, lions' heads, \&c. The gift of William Ofley.-Merchant Taylors' Company.

1591. O. Stoneware Jug, silver mounted.-Robert Napier, Esq. 1592. P. 5755. Silver gilt Cup, baluster stem.-J. P. Dexter, Esq. 1593. Q. 5756. Silver Tazza.-J. P. Dexter, Esq.

1594. R. 3206. Gilt Salt Cellar and Cover, ornamented with repoussé scrolls, \&c., surmounted by an amorino.Corpus Christi College, Oxford.

1594. R. 5757. Stoneware Jug, silver mounted. Maker C. B. -Hugh Owen, Esq.

1595. S. 5651. Ewer and Salver, the gift of Robert Kitchen, broken up during the Bristol Riots. Maker I. B. and a rose above.-Corporation of Bristol.

1597. V. 5678. Silver Ewer and Salver of very fine work, with sea deities and monsters, Neptune and Amphitrite, 
Date. Catalogue No.

\&c., the gift of Henry Howard. Maker I. N. and a rose below.-Corporation of Norwich.

1597. V. Cup, “ the gyfte of John Stuart, A.D. 1600.”-Rev. T. Staniforth.

Cycle IX.-May, 1598, to May, 1618.

1598. A. A parcel gilt Salt Cellar-_Octavius Morgan, Esq.

1599. B. Spice Box, in three compartments.-Dr. and Mrs. Ashford.

1599. B. 5445. Silver Cup, the gift of Grace Gwalter.--Inn Holders' Company.

1599. B. Apostle Spoon.-Rev. T. Staniforth.

1601. D. 5771. Silver gilt Cup, engraved with fruit and flowers. - Earl of Derby.

1601. D. 5422. A circular Salt, the gift of Richard Rogers. " Comptroller of his Majesty's Mint ;" given in 1632 to the Goldsmiths' Company.

1602. E. Spoon, with seal top.-Dr. and Mrs. Ashford.

1603. F. 5772. Silver gilt Ewer and Salver.-Lord Willoughby de Eresby.

1604. G. 5774. Silver covered Cup, engraved flowers. Maker's mark I. H. and a bear.-Lord Willoughby de Eresby.

1604. G. Silver gilt Tankard, engraved scrolls.-L. Huth, Esq. 1605. H. 5481. The "Cockayne" loving Cups in the form of Cocks.-The Skinners' Company.

1605. H. 5414. A Salver, the gift of John Burnell.-Clothworkers' Company.

1606. I. 5777. Silver gilt Salt Cellar, in form of a temple.R. Neville Grenville, Esq.

1606. I. 5776. Silver Cup, with punched ornaments.-Sir T. W. Holburne, Bart.

1607. K. A silver gilt Ewer and Salver, with square escutcheons of repoussé flowers and engraved interlaced designs between.-Louis Huth, Esq.

1607. K. Apostle Spoon.-Rev. T. Staniforth.

1608. L. An old English Spoon.-R. Temple Frere, Esq.

1608. L. 3231. Silver gilt Tazza, on baluster stem.-Christ's College, Cambridge

1609. M. 3231. Silver gilt Tazza, of similar character to the preceding.-Christ's College, Cambridge. 
Date. Catalogue No.

1610. N. An old English Spoon.-Octavius Morgan, Esq.

1610. N. An old English Spoon.-Rev. T. Staniforth.

1611. O. 5406. A tall standing Cup and Cover.-Broderers' Company.

1611. O. 5407. A standing Cup, the gift of John Reeves.Carpenters' Company.

1612. P. A small Paten in Derry Cathedral.-Communicated by Mrs. Dorothea Alexander, of Blackhill, Coleraine.

1613. Q. 5778. Silver gilt Spice Box. Maker's mark, a bow between I. T.-Sir T. W. Holburne, Bart.

1614. R. 5440. Silver gilt circular Salt, given by John Sweete, 1635.-Inn Holders' Company.

1614. R. Two Apostle Spoons.-Rev. T. Staniforth.

1615. S. 3244. Tall Cup and Cover, surmounted by a statuette of Hercules.-St. John's College, Cambridge.

1616. T. 5779. Salver, repoussé subject of Alexander and Darius. Maker's mark, a trefoil leaf.-Sir T. W. Holburne.

1616. T. Dish, inscribed "The dishes of the Arch Duke gotten at the battle of Newporte," and "Taken by the Lord Viscount Wimbaldon in the year 1600."-C. Winn, Esq.

1617. V. 5781. Silver Beaker, engraved with roses, thistles, and pomegranates.-J. P. Dexter, Esq.

Crcle X.-May, 1618, to May, 1638.

1618. a. 5680. Tall silver gilt Tankard, repoussé with strap work and medallions of sea monsters and the arms of Norwich, of fine work.-Corporation of Norwich.

1618. a. Lofty silver Beaker and Cover, engraved with imbricated pattern, surmounted by a female figure, inscribed "The gyfte of Sir William Cockayne, sonne of Roger Cockayne, of Baddesley, Warwickshire, 1619."-E. C. Baring, Esq.

1619. b. Silver Communion Plates.-All Souls' Coll., Oxford. 1620. c. Salt Cellar, with double receptacles and open covers, surmounted by an obelisk.-Dr. G. W. Dasent.

1621. d. 5782. Pair of silver gilt Tankards, given by Richard Wyatt, citizen and carpenter. Maker I. C.-W. Cozier, Esq. 
Date. Catalıgue No.

1622. e. Apostle Spoon.-W. Stirling, Esq., of Keir.

1622. e. Apostle Spoon.-Inn Holders' Company.

1022. e. Chalice and Paten.-St. Antholin's Church, City.

1623. f. 5470. The Camden Cup and Cover, repoussé with leaves and inscription.-Painter Stainers' Company.

1624. g. Silver Paten at Mark, Somersetshire.

1625. h. 5784. Silver gilt Cup, the gift of Richard Chester to the Corporation. Maker T. F.-Viscount Clifden.

1626. $i$. 5482. Rosewater Dish, the gift of Francis Couell.Skinners' Company.

1626. $i$. 5439. Two Salts, given by John Wetterworth.Skinners' Company.

1627. k. Six Silver Apostle Spoons, given in the same year.Innholder's' Company.

1628. l. Two Apostle Spoons.-J. P. Dexter, Esq.

1629. $m$. The Ivatt Cup, given in the same year.-Haberdashers' Company.

1630. n. Silver Chalice.-Queen's College, Oxford.

1631. o. Silver Chalice.-Broomfield Church, Kent.

1632. $p$. Silver Chalice and Paten.-St. James's Church, Dover.

1633. q. Large Silver Flagon.-Corporation of Bristol.

1634. r. 5650. Pair of Tankards, given by John Dodridge.Corporation of Bristol.

1635. s. 5433. Circular Salt, the gift of Sir Hugh Hammersley, Knt.-Haberdashers' Company.

1635. s. Apostle Spoon, inscribed with date of presentation, 1635.-Rev. T. Staniforth.

1636. t. Apostle Spoon.-G. H. Head, Esq.

1636. $t$. Apostle Spoon, inscribed with date of presentation, 1637.-Rev. T. Staniforth.

1637. v. Apostle Spoon, 1637.-Rev. T. Staniforth.

1637. v. 5438. Loving Cup, repoussé work, inscribed "Fides ex Charitate agens valet." - Haberdashers' Company.

Crcle XI.-May, 1638, to May, 1658.

1638.*A. A two-handled Cup and Cover, embossed with flowers.South Kensington Museum.

* The stamp of the church-text $A$ on some of these pieces, towards the end of the ufficial year, appears to have been injured. 
Date. Catalogue No.

1638. A. 5458. Circular Salt, of hour-glass form.-Mercers' Company.

1639. B. 5493. Loving Cup, the gift of Robert Bateman, Chamberlain of London.-Skinners' Company.

1639. B. 5785. Two Wine Cups, the gift of John Harris to the Company of Taylors, Oxford, in 1639.-J. Dunn Gardner, Esq.

1640. C. 5452. Four Cups, the gift of George Humble in 1640.-Leathersellers' Company.

1641. D. 5787. Cup and Cover. Maker R.M.-Viscount Clifden.

1646. I. Silver Spoon.-Rev. T. Staniforth.

1649. M.5417. Tankard, the gift of W. Clissworth, 1661.Coopers' Company

1650. N. 5491. Cup, the gift of George Breton.-Skinners' Company.

1651. O. 5667. Four Apostle Spoons.-Corporation of Hedon.

1652. P. 5788. Covered Cup, said to have been given by Oliver

Cromwell to his daughter Lady Fauconberg.

Maker E. S.-Paul Butler, Esq.

1653. Q. 5504. Cup and Cover, the gift of Thomas Bloodworth in 1682.-Vintners' Company.

1653. Q. 5789. Silver Ladle.-Sir T. W. Holburne, Bart.

1654. R. Apostle Spoon.-Rev. T. Staniforth.

1655. S. 5791. Silver Cup, given by Christopher Pym to the Blacksmiths' Company, inscribed "By hammer and hand, all arts do stand." Maker I. W.-J. P. Dexter, Esq.

1655. S. 5790. Tankard.-J. Dunn Gardner, Esq.

1656. T. Old English Spoon.-Rev. T. Staniforth.

1657. $V$. Apostle Spoon.-Inn Holders' Company.

Crcle XII.-May, 1658, to May, 1678.

1658. A. 5444. Silver gilt Cup, the gift of Edward Osborne.Inn Holders' Company.

1659. 38. 5665. Large Mace, the gift of Henry Guy.-Corporation of Hedon.

1660. $\mathfrak{C}$. 5655. Silver Mace.-Corporation of Doncaster.

1661. 㳉. Three Apostle Spoons.-Inn Holders' Company. 
Date. Catalogue No.

1662. $\mathfrak{E}$. 5794. Silver Salver, repoussé with the labours of Hercules and trophies of arms.-Baron Lionel de Rothschild.

1662. $\mathbb{E} .5901$. Large Salver.-Earl Spencer.

1663. AfF. A Silver Grace Cup._Goldsmiths' Company.

1664. Gr. 5795. Silver Cup.-Paul Butler, Esq.

1665. II Cup given by Charles II. to the Corporation of Oxford.

1666. If. Embossed Silver Cup.-Sir Charles Morgan, Bart.

1667. 政. An Old English Spoon.-O. Morgan, Esq., M.P.

1668. II. Rosewater Dish of the same date.-Queen's College, Oxford.

1669. $\mathfrak{f t}$. Two-handled Bowl and Cover.-Sir C. Morgan, Bart.

1669. $\mathfrak{A t l}$ Cup and Cover engraved with the Royal Arms and the arms of Robertus Creyghtonus; on the cover is inscribed "Ex donis Caroli Secundi Regis."-Dr. and Mrs. Ashford.

1670. $\sqrt{2}$. Porringer, inscribed 1670.—Queen' College, Oxford.

1671. Đ. Communion Plate.-Westminster Abbey.

1672. 非. 5683. Two Tankards, the gift of Thomas Bawtrey Lord Mayor of the City of York in 1673.-Corporation of York.

1673. ․ 5796. Covered Cup. Maker I. N. In fine gold, plain with scroll handles, coiled serpent on the cover. (Hall Marks the same as on silver).-J. W. Walrond, Esq.

1674. 2R. 5799. Two-handled Cup, the gift of Sir John Cutler to Charles Lush. Maker I. N.-Paul Butler, Esq.

1674. $\mathfrak{R}$. 5797. Two Cups fitting into each other, matted surface.-W. B. Stopford, Esq.

1675. \$. 5800. Set of 3 Castors. Maker R.A.-J. Rainey, Esq.

1676. T. Cup and Cover with two handles.-S. K. Museum.

1676. $\mathfrak{T}$. Silver Tankard.-Corporation of Oxford.

1677. F. 8103. Cup.-Messrs. Hunt and Roskell.

Cycle XIII.-May, 1678, to March, 1697.

1678. a. 5803. Two-handled Cup, chased with leaves.-J. $P$. Dexter, Esq.

1679. b. 5804. Silver Ladle.-J. P. Dexter, Esq.

1680. c. 5461. The "Brett" Loving Cup and Cover.-Merchant Taylors' Company. 
Date. Catalogue No.

1681. o. 5806. Large Silver Cistern, the handles in form of peacocks, resting on four lions' claws, weighing 2000 ounces. Maker R. L.-Duke of Rutland.

1682. e. 5807. Tankard.-Sir T. W. Holburne, Bart.

1682. ⿷. Two Spoons with heart-shaped ends.-Rev. T. Staniforth. 1683. f. 5808. Silver Tazza with figures in the centre, of Jupiter, Diana, \&c. Maker W. F.-Sir W. C. Trevelyan, Bart.

1683. f. Oval Casket and Cover, engraved with Chinese figures, birds, \&c.-South Kensington Museum.

1683. f. Basin engraved with Chinese figures, trees, fountains and birds.-J. Dunn Gardner, Esq.

1684. a. 5809. Covered Bowl, pounced with Chinese figures, Maker I. I. and lis._Sir T. W. Holburne, Bart.

1695. b. Silver Tankard.-Messrs. Garrard.

1686. i. 5495. Tankard, the gift of James Langdon Reynolds. Maker I. R. crowned.-Skinners' Company.

1687 k. Mace with the Arms of James II.-Mayor and Corporation of Newcastle-upon-Tyne.

1688. I. 5810. Circular Salver, engraved with Chinese figures. -J. P. Dexter, Esq.

1688. I. 5811. Pair of Candlesticks, in form of architectural columns.-W. Maskell, Esq.

1689. m. Spoon with heart-shaped end.-Rev. T. Staniforth.

1690. n. 5813. Silver Tankard, the Cover in form of a helmet repoussé with trophies, \&c. Maker G. G.-Baron Lionel de Rothschild.

1691. o. Embossed Altar Candlesticks.-Westminster Abbey.

1692. p. Silver Cup.-Jesus College, Oxford.

1693. q. Pair of Wine Cups.-J. Dunn Gardner, Esq.

1694. r. Silver Loving Cup.-Mercers' Company.

1695. \$. 5815. Silver Cup of Richard Deeble, 1724.-P. W. Doyle, Esq.

1696. t. 5816. A pair of Fire Dogs at Hampton Court. Maker M. A.-Her Majesty the Queen.

Cycle XIV.-March, 1697, to May, 1716.

1697. A. 5817. Tea Pot of rock-work, vine-leaves and grapes. —Sir T. W. Holburne, Bart. 
Date. Catalogue No.

1697. B. 5818. Silver-gilt Cup with Cover, on the top the Royal Arms and W. R. III; and a pair of large pricket Candlesticks on tripod stems, with the Royal Arms of W. III. Maker $\underset{\mathbf{A}}{\mathbf{D}}$ - The Duke of Manchester.

1698. C. 5821. Pair of silver-gilt Candlesticks.-Rev. G. Jepson. 1699. D. Silver Candlesticks.-C. H. Leigh, Esq.

1700. E. 5902. Helmet-shaped Ewer, engraved with the Royal Arms of William III. Maker H. A. (H. Auguste?). -Lord Willoughby de Eresby.

1700. E. 5898. Large Silver Fountain, engraved with the Marlborough arms. Maker H. A. (H. Auguste?).-Earl Spencer.

1701. F. 5894. 'Two Ewers and Salvers, engraved with the Marlborough arms; and large Cistern weighing 1920 ounces. Marlborough plate. Maker H. A. (Henri Auguste?).-Earl Spencer.

1701. F. 5896. Pair of massive Flagons. Marlborough plate Maker G. O. crowned.-Earl Spencer.

1701. F. 5907. Ewer and Salver. Maker W. I. two stars above and lis below.-Marquess of Abercorn.

1702. G. 5910. Helmet-shaped Ewer with female bust handle, engraved with the Royal Arms and motto "Semper eadem." Maker M. E.-Lord Willoughby de Eresby.

1703. H. 5911. Tureen. Maker Ne-Lord Bateman.

1703. H. Silver Porringer.-R. Temple Frere, Esq.

1704. I. Silver Porringer.-R. Temple Frere, Esq.

1705. K. 5912. Two-handled Cup and Cover, with the Royal Arms, presented by Queen Anne to Sir John Leake. -Paul Butler, Esq.

1706. L. 5913. Gilt Communion Service, the salver engraved with the descent from the cross.-Earl of Stamford and Warrington.

1706. L. 5449. Loving Cup, given by William Humphreys.Ironmongers' Company.

1707. M. Old English Spoon.-O. Morgan, Esq., M.P.

1708. $N$. The Goldsmiths' Company's Minutes.

1709. O. Silver Porringer.-R. Temple Frere, Esq.

1710. P. Silver Porringer. - R. Temple Frere, Esq. 
Date. Catalogue No.

1711. Q. 5914. Four circular Salt Cellars. Maker P. A. under a rose.-W. Maskell, Esq.

1712. R. 5450. Loving Cup, the gift of Randulph Lane, in the same year.-Ironmongers' Company.

1713. S. Silver Tankard.-J. Dunn Gardner, Esq.

1714. T. 5432. Loving Cup, the gift of Hugh Radcliffe.Haberdashers' Company.

1715. $V$. Six Spoons.-Rev. T. Staniforth.

Cycle XV.-May, 1716, to May, 1736.

1717. B. Silver Monteith or punch bowl, with a detached escallop rim.-J. G. Fanshawe, Esq.

1717. B. Silver Porringer.-R. Temple Frere, Esq.

1718. C. 5919. Silver Waiter.-J. P. Dexter, Esq.

1718. C. 5920. Silver Basin and Cover. Maker W. I. two stars and lis.-W. Stirling, Esq., of Keir.

1719. D. 5921. Pair of covered Cups, chased with scrolls and head of Bacchus.-Earl of Stamford and Warrington.

1720. E. 5657. Sugar Tongs.-Corporation of Doncaster.

1721. F. 5677. Cup, the gift of John Kirkpatrick.-Corporation of Norwich.

1722. G. Silver Paten.-Crowhurst Church.

1725. K. 6005. Silver gilt Oar, a copy of a more ancient one of the time of Queen Elizabeth, $3 \mathrm{ft}$. 3 in. long inscribed, "This oar, a badge of authority used by the ancient Corporation of Boston, was sold by the modern Town Council in 1832, and purchased by Francis Thurkill, Esq., an Alderman of that Borough, by whose widow it was presented in 1840 to the Earl Brownlow."-Earl Brownlow.

1727. M. 5923. Helmet-shaped Ewer, engraved with the arms of George I.-J. P. Dexter, Esq.

1728. N. 5928. Gilt Toilet Service. Maker I. L.-Earl of Stamford and Warrington.

1729. O. 5929. Silver Basin, scrolls and flowers._Lord Bateman.

1732. R. 5934. Pair of gilt Tankards. Maker P. L. (*Paul

Lamerie) star and crown above, lis below.-Earl of

Stamford and Warrington.

* The first entry of Paul de Lamerie in the mark book of the Goldsmiths Hall occurs in 1712, when he resided at the Golden Ball in Windmill Street, in the Haymarket. In 1739 he removed to Garard Street, or Gerard Street, Soho. His mark was P. L. crowned, being the Crown Goldsmith. 
Date. Catalogue No.

1733. S. 5938. Bread Basket, of wicker pattern. Maker P. L. (Paul Lamerie), crown and star above, lis below.J. Dunn Gardner, Esq.

1734. T. 5671. The Walpole Mace. Maker T. R.-Corporation of Norwich.

1735. V. Tea Pot, melon-shaped, chased with shells and flowers. J. Dunn Gardner, Esq.

Crcle XVI.-May, 1736, to May, 1756.

1736. a. Sacramental Flagon.-Crowhurst Church.

1737. b. 5939. Chalice and Paten.-Messrs. Hunt and Roskell.

1739. d. Spoon, the stem surmounted by a group representing Charity.-Hon. G. Mostyn.

1740. e. 5426. Pair of Vases and Covers, chased with Deities and emblems of the arts and sciences, scroll handles of terminal figures. Maker's initials T. T.-Goldsmiths' Company.

1741. f. 5424. A large Ewer and Salver, handsomely chased with Heathen Deities, Minerva holding a scroll inscribed, "By prudence and good management I am restored," by Paul Lamerie. - Goldsmiths' Company.

174.2. g. 5940. Silver Cup and Cover, elaborately chased. Maker P. L. (Paul Lamerie) crown and star above, lis below.-Messrs. Hunt and Roskell.

1743. h. 5941. Pair of Silver Dishes. Maker N. S., star above. -Her Majesty the Queen.

1747. m. 5943. Pair of Tortoiseshell Caddies, silver-mounted, ornamented with repoussé work in figures, scrolls, \&c. Maker P. L. (Paul Lamerie) crown and star above, lis below.-J. Dunn Gardner, Esq.

1748. n. Pair of Vases and Covers, with acanthus leaf ornament. Jos. Bond, Esq.

1750. p. 5944. Cruet Stand, by Paul Lamerie. - J. Dunn Gardner, Esq.

1752. r. 5649. State Sword.-Corporation of Bristol.

1753. s. 5945. Set of Castors.-W. Stirling, Esq., of Keir.

1754. t. 5948. Two Tea Caddies. Maker M. F. - Earl of Stamford and Warrington.

1755. u. 5950. Milk Pot, repoussé with vine leaves and grapes. Maker P. B-Sir T. W. Holburne, Bart. 
Date. Catalogue No.

Crcle XVII.-May, 1756, to May, 1776.

1756. A. 5951. Tea Kettle, gourd-shaped, engraved with landscapes and figures; on a stand.-J. D. Gardner, Esq.

1758. ㄷ. 5952. Ewer. Maker T. H.-O. E. Coope, Esq.

1759. 建. A two-handled Vase, No. 9145 ; and a Coffee Pot, 393, '64.- South Kensington Museum.

1760. (E. Jug, plain with ribbed neck.-J. D. Gardner, Esq.

1761. ffF. 5953. Bread Basket, of pierced work and arms of George III.-Her Majesty the Queen.

1765. 活.5961. Tea Kettle and Milk Pot. Maker I. K. crowned. Lord Bateman.

1765. 抔. Silver Tankard.-Dr. and Mrs. Ashford.

1767. $\mathfrak{A t}$. 5963. Two small Waiters._Lord Bateman.

1768. $\$$. Coffee Pot, repoussé with flowers and love knots.-

J. D. Gardner, Esq.

1770. 稩. 5965. Gilt Ewer and Cover. Maker's mark S. C:I. C. - Sir T. W. Holburne, Bart.

1771. (1. 5966. Tankard.-W. Stirling, Esq., of Keir.

1772. 2R. 5967. Pair of Pillar Candlesticks.-Lord Bateman.

1772. 2R. Fluted Vase and Cover, satyr head handles, festoons, \&c., fluted body, square foot.-S. K. Museum.

1773. \&. Tea Kettle and Stand, chased with foliage, by Paul Lamerie.-Messrs. Hancock.

1774. $\mathfrak{d}$. Candlestick. Brett Collection.-W. Meyrick, Esq.

Cycle XVIII.-May, 1776, to May, 1796.

1776. a. Pair of Candlesticks, in form of figures holding flowers. -Messrs. Hancock.

1778. c. Set of three Vases, designed by Adams. - Percy Doyle, Esq.

1779. d. 5969. Pair of Vases, openwork body with rams' heads and festoons.-J. W. Brett, Esq.

1780. e. Cream Jug, repoussé with flowers and scrolls, stalk handle.-J. D. Gardner, Esq.

1785. k. Pair of Salts, open ribs, festoons and lions' heads.J. D. Gardner, Esq.

1786. 1. 5971. Pair of Cups, with ivory plaques. Maker I. B. - Her Majesty the Queen.

1788. n. 5976. Silver gilt Salt Cellars. Maker's mark M. N : R. G.-Lord Bateman.

1792. r. 5978. Silver Globe Inkstand.-J. W. Brett, Esq. 


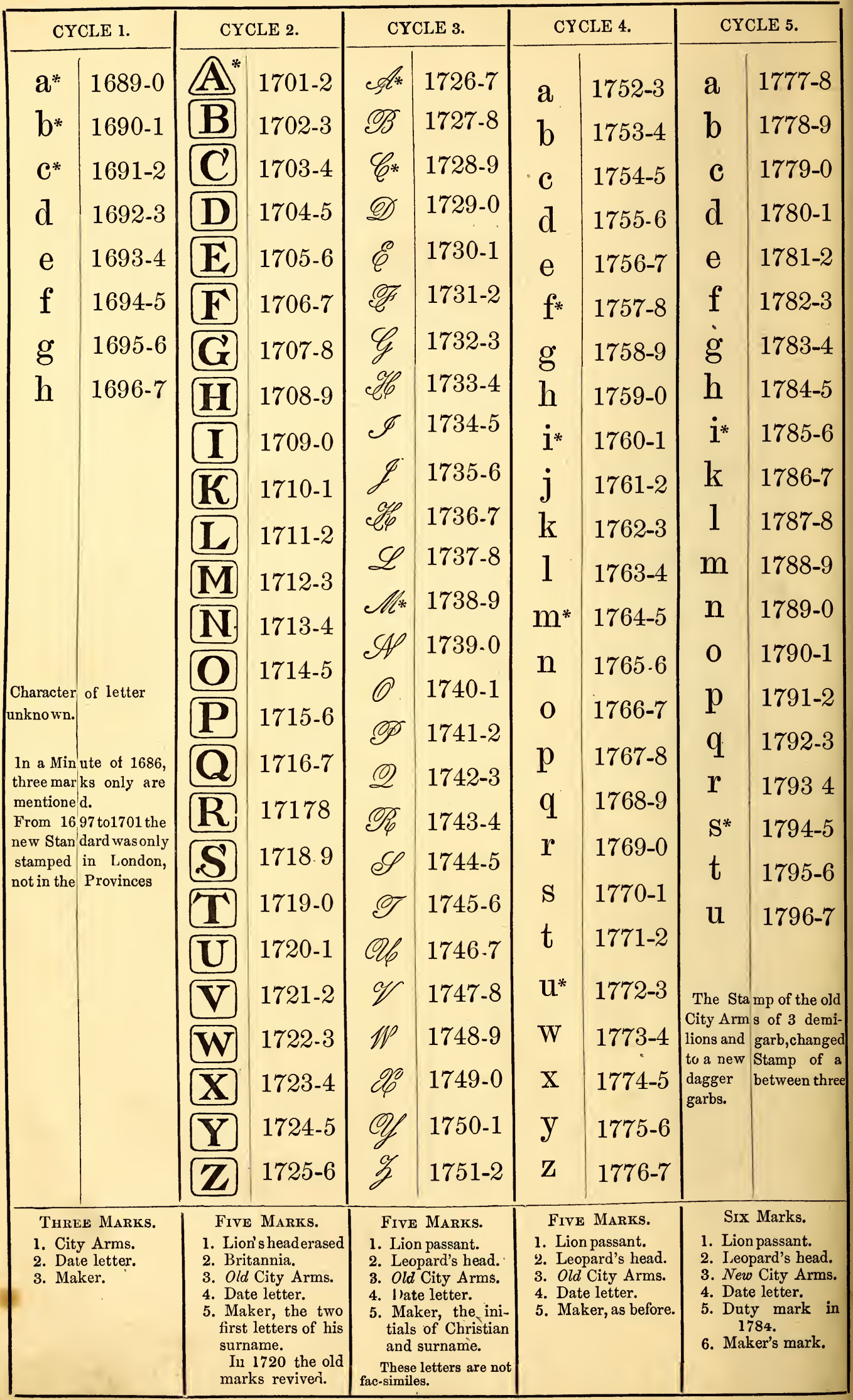




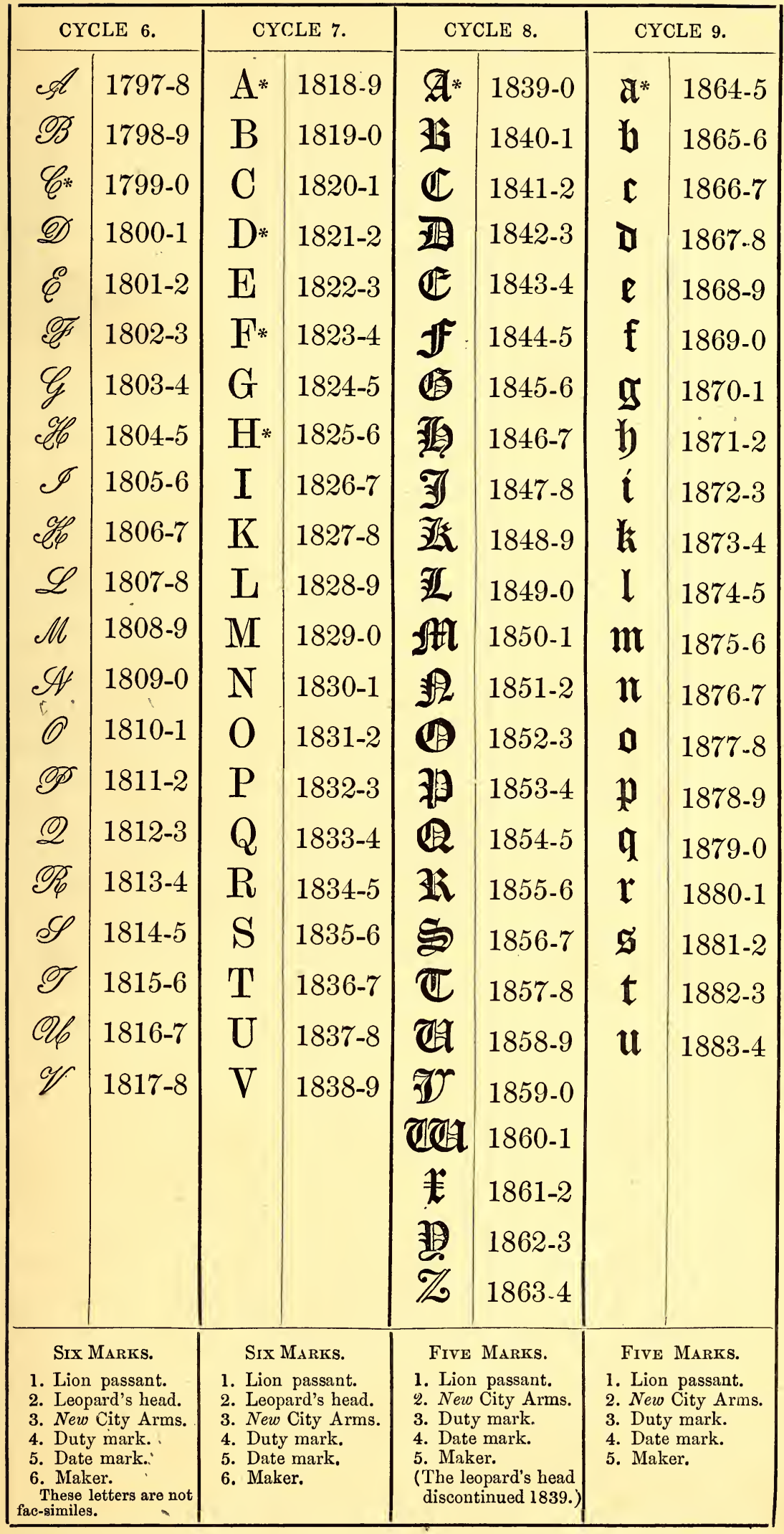

Note.-The letters marked with an asterisk are verified by the minutes or examples of plate. 
EXETER ASSAY OFFICE LETTERS.

\begin{tabular}{|c|c|c|c|c|c|c|c|}
\hline \multicolumn{2}{|c|}{ CYCLE 1.} & \multicolumn{2}{|c|}{ CYCLE 2.} & \multicolumn{2}{|c|}{ CYCLE 3.} & \multicolumn{2}{|c|}{ CYCLE 4.} \\
\hline & $\begin{array}{l}\text { AUGUST } \\
1701-2\end{array}$ & a & $\begin{array}{c}\text { AUGUST } \\
1725-6\end{array}$ & & $\begin{array}{c}\text { AUGUST } \\
1749-0\end{array}$ & $a$ & $\begin{array}{c}\text { AUGUST } \\
1773-4\end{array}$ \\
\hline & $1702-3$ & & $1726-7$ & & $1750-1$ & & $1774-5$ \\
\hline & $1703-4$ & & $1727-8$ & & $1751-2$ & & $1775-6$ \\
\hline & $1704-5$ & & $1728-9$ & & $1752-3$ & & $1776-7$ \\
\hline & $1705-6$ & e & $1729-0$ & & $1753-4$ & e & $1777-8$ \\
\hline & 1706-7 & & $1730-1$ & & $1754-5$ & & 1778-9 \\
\hline & $1707-8$ & & $1731-2$ & & $1755-6$ & & $1779-0$ \\
\hline & 1708-9 & & $1732-3$ & & $1756-7$ & & $1780-1$ \\
\hline & $1709-0$ & & $1733-4$ & & $1757-8$ & & $1781-2$ \\
\hline & 1710-1 & & $1734-5$ & & $1758-9$ & & $1782-3$ \\
\hline & $1711-2$ & & $1735-6$ & & $1759-0$ & & $1783-4$ \\
\hline & $1712-3$ & $m$ & $1736-7$ & & $1760-1$ & $\mathrm{~m}$ & $1784-5$ \\
\hline & $1713-4$ & $\mathbf{n}$ & $1737-8$ & & $1761-2$ & $\mathbf{n}$ & $1785-6$ \\
\hline & $1714-5$ & $\mathbf{O}$ & $1738-9$ & & $1762-3$ & $\mathbf{O}$ & $1786-7$ \\
\hline & $1715-6$ & p & $1739-0$ & & $1763-4$ & & $1787-8$ \\
\hline & $1716-7$ & 4 & 1740-1 & & $1764-5$ & & $1788-9$ \\
\hline & $1717-8$ & $\mathbf{r}$ & $1741-2$ & & $1765-6$ & $\mathbf{r}$ & 1789-0 \\
\hline & $1718-9$ & & $1742-3$ & & $1766-7$ & & 1790-1 \\
\hline & $1719-0$ & & $1743-4$ & & $1767-8$ & $t$ & 1791-2 \\
\hline & 1720-1 & $\mathbf{V}$ & $1744-5$ & & $1768-9$ & $\mathbf{V}$ & $1792-3$ \\
\hline & $1721-2$ & $\mathbf{W}$ & $1745-6$ & & 1769-0 & W & $1793-4$ \\
\hline & $1722-3$ & $\mathbf{X}$ & $1746-7$ & & $1770-1$ & $\mathbf{X}$ & $1794-5$ \\
\hline & $1723-4$ & $y$ & $1747-8$ & & $1771-2$ & $\mathrm{Y}$ & $1795-6$ \\
\hline$Z$ & $1724-5$ & $\mathbf{Z}$ & $1748-9$ & 2 & $1772-3$ & $\mathbf{Z}$ & $1796-7$ \\
\hline $\begin{array}{l}\text { FIVE } \\
\text { 1. Lion's } \\
\text { 2. Britar } \\
\text { 3. Castle } \\
\text { 4 Date } \\
\text { 5. Make } \\
\text { After } 17\end{array}$ & $\begin{array}{l}\text { STAMPS. } \\
\text { Head erased. } \\
\text { aia. } \\
\text { Iark. } \\
\text { s Initials. } \\
9 \text { the marks of } \\
\end{array}$ & $\begin{array}{l}\text { Fivr } \\
\text { 1. Lior } \\
\text { 2. Leoo } \\
\text { 3. Cast } \\
\text { 4. Dat } \\
\text { 5. Mak } \\
\text { old stand }\end{array}$ & $\begin{array}{l}\text { STaMps. } \\
\text { passant. } \\
\text { ard's Head. } \\
\text { e. } \\
\text { Mark. } \\
\text { er's Initials. } \\
\text { rd resumed.7 }\end{array}$ & $\begin{array}{l}\text { Fivr } \\
\text { 1. Lion } \\
\text { 2. Leol } \\
\text { 3. Cast } \\
\text { 4. Dat } \\
\text { 5. Mak }\end{array}$ & $\begin{array}{l}\text { STAMPS. } \\
\text { passant. } \\
\text { ard's Head. } \\
\text { e. } \\
\text { Mark. } \\
\text { r's Initials. }\end{array}$ & $\begin{array}{l}\text { Fiv } \\
\text { 1. Lion } \\
\text { 2. Castl } \\
\text { 3. Date } \\
\text { 4. Make } \\
\text { 5. Duty } \\
\text { He }\end{array}$ & $\begin{array}{l}\text { STAMPS. } \\
\text { assant. } \\
\text { Cark. } \\
\text { 's Initials. } \\
\text { aark of King's } \\
\text { l, } 1784 \text {. }\end{array}$ \\
\hline
\end{tabular}

Notes.-The early Hall Mark previous to 1800 has only two towers to the castle, the left one shorter than the other, with some object on the top.

The letters in the two first Cyçles are mostly on regular shields with pointed bases, the subsequent letters are on square shields, with the corners slightly cut off as a rule, but there are some exceptions. The letters placed in shields are examples in Dr. Ashford's possession. 
EXETER ASSAY OFFICE LETTERS.

\begin{tabular}{|c|c|c|c|c|c|c|c|}
\hline \multicolumn{2}{|c|}{ CYCLE 5.} & \multicolumn{2}{|c|}{ CYCLE 6.} & \multicolumn{2}{|c|}{ CYCLE 7.} & \multicolumn{2}{|c|}{ CYCLE 8.} \\
\hline & $\begin{array}{l}\text { AUGUUST } \\
1797-8\end{array}$ & a & $\begin{array}{l}\text { AUGUST } \\
1817-8\end{array}$ & (x) & $\begin{array}{l}\text { AUGUST } \\
1837-8\end{array}$ & & $\begin{array}{c}\text { AUGUST } \\
1857-8\end{array}$ \\
\hline & $1798-9$ & b & $1818-9$ & 31 & $1838-9$ & & $1858-9$ \\
\hline & $1799-0$ & C & $1819-0$ & $\mathbb{C}$ & $1839-0$ & & $1859-0$ \\
\hline & $1800-1$ & d & $1820-1$ & 武 & $1840-1$ & & $1860-1$ \\
\hline & $1801-2$ & e & $1821-2$ & $\mathbb{E}$ & $1841-2$ & 4 & $1861-2$ \\
\hline & $1802-3$ & $f^{\circ}$ & $1822-3$ & $\mathfrak{f}$ & $1842-3$ & & $1862-3$ \\
\hline & $1803-4$ & $g$ & $1823-4$ & 6 & $1843-4$ & & $1863-4$ \\
\hline & $1804-5$ & h & $1824-5$ & 婂 & $1844-5$ & & $1864-5$ \\
\hline & $1805-6$ & 1 & $1825-6$ & 3] & $1845-6$ & & $1865-6$ \\
\hline & $1806-7$ & k & $1826-7$ & 逊 & $1846-7$ & & $1866-7$ \\
\hline & $1807-8$ & 1 & $1827-8$ & 近 & $1847-8$ & נ & $1867-8$ \\
\hline & $1808-9$ & $\mathrm{~m}$ & $1828-9$ & At & $1848-9$ & & $1868-9$ \\
\hline & $1809-0$ & $\mathbf{n}$ & $1829-0$ & 12 & $1849-0$ & & $1869-0$ \\
\hline & $1810-1$ & $\mathbf{O}$ & $1830-1$ & $\mathbb{B}$ & $1850-1$ & & $1870-1$ \\
\hline & $1811-2$ & $\mathrm{P}$ & 1831-2 & 羽 & $1851-2$ & & $1871-2$ \\
\hline & $1812-3$ & $q$ & $1832-3$ & $\mathbb{Q}$ & $1852-3$ & & $1872-3$ \\
\hline & $1813-4$ & $\mathbf{r}$ & $1833-4$ & $3 \mathbf{R}$ & $1853-4$ & & $1873-4$ \\
\hline $\mathbf{S}$ & $1814-5$ & $\mathbf{S}$ & $1834-5$ & 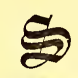 & $1854-5$ & $S$ & $1874-5$ \\
\hline $\mathrm{T}$ & $1815-6$ & $t$ & $1835-6$ & $\mathbb{U}$ & $1855-6$ & $\mathrm{~T}$ & $1875-6$ \\
\hline $\mathbf{U}$ & $1816-7$ & $\mathbf{u}$ & $1836-7$ & 咊 & $1856-7$ & $\mathbf{U}$ & $1876-7$ \\
\hline $\begin{array}{l}\mathrm{Fr} \\
\text { 1. } \mathrm{Li} \\
\text { 2. } \mathrm{Ca} \\
\text { 3. } \mathrm{Ki} \\
\text { 4. } \mathrm{Da}^{2} \\
\text { 5. } \mathrm{M} \text {. }\end{array}$ & $\begin{array}{l}\text { STAMPS. } \\
\text { passant. } \\
\text { el } \\
\text { s Head. } \\
\text { Letter. } \\
\text { r's Initials. }\end{array}$ & $\begin{array}{l}\mathrm{FI} \\
\text { 1. } \mathrm{Li} \\
\text { 2. } \mathrm{Ca} \\
\text { 3. } \mathrm{Ki} \\
\text { 4. } \mathrm{Da} \\
\text { 5. Ma }\end{array}$ & $\begin{array}{l}\text { STAMPs. } \\
\text { passant. } \\
\text { e. } \\
\text { s Head. } \\
\text { Letter. } \\
\text { 'r's Initials. }\end{array}$ & $\begin{array}{l}\mathrm{Fr} \\
\text { 1. } \mathrm{Li} \\
\text { 2. } \mathrm{Cg} \\
\text { 3. } \mathrm{Q} \\
\text { 4. } \mathrm{D} \\
\text { 5. } \mathrm{M}\end{array}$ & $\begin{array}{l}\text { STAMPs. } \\
\text { passant. } \\
\text { e; } \\
\text { 's Head. } \\
\text { Letter. } \\
\text { 'r's Initials. }\end{array}$ & $\begin{array}{l}\text { Fivr } \\
\text { 1. Lion } \\
\text { 2. Cast } \\
\text { 3. Que } \\
\text { 4. Date } \\
\text { 5. Mak }\end{array}$ & $\begin{array}{l}\text { STamps. } \\
\text { passant. } \\
\text { e' } \\
\text { 's Head. } \\
\text { Letter. } \\
\text { r's Initials. }\end{array}$ \\
\hline
\end{tabular}


72 NEWCASTLE-UPON-TYNE ASSAY OFFICE LETTERS.

\begin{tabular}{|c|c|c|c|c|c|c|c|}
\hline \multicolumn{2}{|c|}{ CYCLE 1.} & \multicolumn{2}{|c|}{ CYCLE 2.} & \multicolumn{2}{|c|}{ CYCLE 3.} & \multicolumn{2}{|c|}{ CYCLE 4.} \\
\hline A & $1702-3$ & 21 & $1721-2$ & A & $1740-1$ & $\mathscr{A}$ & $1769-0$ \\
\hline B & $1703-4$ & 13 & 1722.3 & B & $1741-2$ & $\mathscr{B}$ & $1770-1$ \\
\hline $\mathrm{C}$ & $1704-5$ & $\mathbb{a}$ & $1723-4$ & C & $1742-3$ & $\mathscr{C}$ & $1771-2$ \\
\hline D & $1705-6$ & (1D & $1724-5$ & $D$ & $1743-4$ & $\mathscr{D}$ & $1772-3$ \\
\hline $\mathrm{E}$ & $1706-7$ & $\mathbb{E}$ & $1725-6$ & $\mathrm{E}$ & $1744-5$ & $\mathscr{E}$ & $1773-4$ \\
\hline $\mathbf{F}$ & $1707-8$ & $\mathbb{I}$ & $1726-7$ & $\mathbf{F}$ & 1745.6 & $\mathscr{H}$ & $1774-5$ \\
\hline $\mathrm{G}$ & $1708-9$ & (1) & $1727-8$ & G & $1746-7$ & $\mathscr{G}$ & $1775-6$ \\
\hline $\mathrm{H}$ & $1709-0$ & 1 & $1728-9$ & $\mathrm{H}$ & $1747-8$ & $\mathscr{H}$ & $1776-7$ \\
\hline I & $1710-1$ & 3) & $1729-0$ & I & $1748-9$ & $\mathscr{I}$ & $1777-8$ \\
\hline $\mathbf{K}$ & $1711-2$ & 虹 & $1730-1$ & K & $1749-0$ & $\mathscr{H}$ & $1778-9$ \\
\hline $\mathbf{L}$ & $1712-3$ & 1 & $1731-2$ & $\mathbf{L}$ & $1750-1$ & $\mathscr{L}$ & 1779.0 \\
\hline $\mathbf{M}$ & $1713-4$ & ald & $1732-3$ & M & $1751-2$ & $\mathscr{M}$ & $1780-1$ \\
\hline $\mathbf{N}$ & $1714-5$ & $\sqrt{2}$ & $1733-4$ & $\mathrm{~N}$ & $1752-3$ & $\mathscr{A}$ & $1781-2$ \\
\hline O & $1715-6$ & ID & $1734-5$ & $\mathrm{O}$ & $1753-4$ & 0 & $1782-3$ \\
\hline $\mathbf{P}$ & $1716-7$ & 119 & $1735-6$ & $\mathrm{P}$ & $1754-5$ & $\mathscr{P}$ & $1783-4$ \\
\hline $\mathbf{Q}$ & $1717-8$ & $\mathbb{D}$ & $1736-7$ & $\mathbf{Q}$ & $1755-6$ & $\mathscr{Q}$ & $1784-5$ \\
\hline $\mathbf{R}$ & $1718-9$ & 㼛 & $1737-8$ & $\mathbf{R}$ & $1756-7$ & $\mathscr{O}$ & $1785-6$ \\
\hline $\mathbf{S}$ & $1719-0$ & 8 & $1738-9$ & S & $1757-8$ & $\mathscr{S}$ & $1786-7$ \\
\hline $\mathbf{T}$ & $1720-1$ & $\mathbb{Z}$ & $1739-0$ & $\mathrm{~T}$ & $1758-9$ & $\mathscr{T}$ & $1787-8$ \\
\hline & & & & $\mathrm{U}$ & $1759-0$ & Ob & 1788-9 \\
\hline & & & & V & $1760-1$ & $\mathscr{V P}$ & $1789-0$ \\
\hline & & & & W & $1761-2^{*}$ & $\mathscr{W}$ & $1790-1$ \\
\hline
\end{tabular}

* A lapse of eight years. 
NEWCASTLE-UPON-TYNE ASSAY OFFICE LETTERS. 73

\begin{tabular}{|c|c|c|c|c|c|c|c|}
\hline \multicolumn{2}{|c|}{ CYCLE 5.} & \multicolumn{2}{|c|}{ CYCLE 6.} & \multicolumn{2}{|c|}{ CYCLE 7.} & \multicolumn{2}{|c|}{ CYCLE 8.} \\
\hline & $1791-2$ & $\mathbf{a}$ & $1815-6$ & & $1839-0$ & a & 1864.5 \\
\hline & $1792-3$ & b & $1816-7$ & & $1840-1$ & b & $1865-6$ \\
\hline & $1793-4$ & C & $1817-8$ & & $1841-2$ & c & $1866-7$ \\
\hline & $1794-5$ & d & 1818.9 & & $1842-3$ & d & $1867-8$ \\
\hline & $1795-6$ & e & $1819-0$ & & $1843-4$ & e & $1868-9$ \\
\hline & $1796-7$ & $f$ & $1820-1$ & & $1844-5$ & $f$ & $1869-0$ \\
\hline & $1797-8$ & $\mathrm{~g}^{\circ}$ & $1821-2$ & & $1845-6$ & $g^{\circ}$ & $1870-1$ \\
\hline & $1798-9$ & $\mathrm{~h}$ & $1822-3$ & & $1846-7$ & h & $1871-2$ \\
\hline & $1799-0$ & 1 & $1823-4$ & & $1847-8$ & 1 & $1872-3$ \\
\hline & & & & & $1848-9$ & & \\
\hline & $1800-1$ & k & $1824-5$ & & $1849-0$ & k & $1873-4$ \\
\hline & $1801-2$ & & $1825-6$ & & $1850-1$ & 1 & $1874-5$ \\
\hline & $1802-3$ & $\mathrm{~m}$ & $1826-7$ & & $1-2$ & $\mathrm{~m}$ & $1875-6$ \\
\hline & $1803-4$ & $\mathbf{n}$ & $1827-8$ & & $1852-3$ & $\mathbf{n}$ & $1876-7$ \\
\hline & $1804-5$ & $\mathbf{O}$ & $1828-9$ & & 1853.4 & $\mathbf{O}$ & $1877-8$ \\
\hline & $1805-6$ & $\mathrm{P}$ & $1829-0$ & & $1854-5$ & $\mathrm{p}$ & $1878-9$ \\
\hline & $1806-7$ & $q$ & $1830-1$ & & $1855-6$ & $q$ & $1879-0$ \\
\hline & $1807-8$ & $\mathbf{r}$ & $1831-2$ & & $1856-7$ & $\mathbf{r}$ & $1880-1$ \\
\hline & $1808-9$ & $\mathbf{S}$ & $1832-3$ & & $1857-8$ & $\mathbf{S}$ & $1881-2$ \\
\hline & $1809-0$ & $t$ & $1833-4$ & & $1858-9$ & $t$ & $1882-3$ \\
\hline & $1810-1$ & V & $1834-5$ & & $1859-0$ & $\mathbf{u}$ & $1883-4$ \\
\hline & $1811-2$ & $\mathbf{W}$ & $1835-6$ & W & $1860-1$ & $\mathbf{W}$ & $1884-5$ \\
\hline & 1812-3 & $\mathbf{X}$ & $1836-7$ & & $1861-2$ & $\mathbf{X}$ & 1885.6 \\
\hline$Y$ & $1813-4$ & $y$ & $1837-8$ & & $1862-3$ & $y$ & $1886-7$ \\
\hline Z & 1814.5 & $\mathbf{Z}$ & $1838-9$ & Z & $1863-4$ & $\mathbf{Z}$ & $1887-8$ \\
\hline
\end{tabular}

Note.-The usual stamps found upon plate assayed at Newcastle are:1. The Lion passant. 2. The leopard's head crowned. 3. The town mark of three castles. 4. The letter or date mark; and 5. The maker's initials. After 1784 the duty mark of the sovereign's head is added. 
BIRMINGHAM ASSAY OFFICE LETTERS.

\begin{tabular}{|c|c|c|c|c|c|c|c|}
\hline \multicolumn{2}{|c|}{ CYCLE 1.} & \multicolumn{2}{|c|}{ CYCLE 2.} & \multicolumn{2}{|c|}{ CYCLE 3.} & \multicolumn{2}{|c|}{ CYCLE 4.} \\
\hline A & $\begin{array}{c}\text { JULY } \\
1773-4\end{array}$ & a & $\begin{array}{c}\text { JULY } \\
1799-0\end{array}$ & $\mathfrak{A}$ & $\begin{array}{c}\text { JULY } \\
1825-6\end{array}$ & A & $\begin{array}{c}\text { JOLY } \\
1850-1\end{array}$ \\
\hline B & $1774-5$ & b & $1800-1$ & 33 & $1826-7$ & B & $1851-2$ \\
\hline $\mathrm{C}$ & $1775-6$ & C & $1801-2$ & e & $1827-8$ & $\mathrm{C}$ & $1852-3$ \\
\hline D & $1776-7$ & d & $1802-3$ & 进 & $1828-9$ & $\mathrm{D}$ & $1853-4$ \\
\hline $\mathrm{E}$ & $1777-8$ & e & 1803-4 & $\mathbb{E}$ & $1829-0$ & $\mathrm{E}$ & $1854-5$ \\
\hline $\mathrm{F}$ & $1778-9$ & $\mathrm{f}$ & $1804-5$ & $\mathbb{f}$ & $1830-1$ & $\mathrm{~F}$ & $1855-6$ \\
\hline G & $1779-0$ & $g$ & $1805-6$ & (6) & $1831-2$ & $\mathrm{G}$ & $1856-7$ \\
\hline $\mathrm{H}$ & $1780-1$ & $\mathrm{~h}$ & $1806-7$ & 襐? & $1832-3$ & $\mathrm{H}$ & $1857-8$ \\
\hline$I$ & $1781-2$ & $\mathrm{i}$ & $1807-8$ & 3) & $1833-4$ & $I$ & $1858-9$ \\
\hline $\mathbf{J}$ & $1782-3$ & j & $1808-9$ & 五后 & $1834-5$ & K & $1859-0$ \\
\hline K & $1783-4$ & $\mathrm{k}$ & $1809-0$ & 距 & $1835-6$ & L & $1860-1$ \\
\hline $\mathrm{L}$ & $1784-5$ & 1 & $1810-1$ & $\Xi t$ & $1836-7$ & M & $1861-2$ \\
\hline M & $1785-6$ & $\mathrm{~m}$ & $1811-2$ & $\$ 2$ & $1837-8$ & $\mathrm{~N}$ & $1862-3$ \\
\hline $\mathrm{N}$ & $1786-7$ & $\mathbf{n}$ & $1812-3$ & (1) & $1838-9$ & 0 & $1863-4$ \\
\hline 0 & $1787-8$ & 0 & $1813-4$ & 非 & $1839-0$ & $\mathbf{P}$ & $1864-5$ \\
\hline $\mathrm{P}$ & $1788-9$ & $\mathrm{p}$ & $1814-5$ & $\mathbb{Q}$ & $1840-1$ & $Q$ & $1865-6$ \\
\hline $\mathbf{Q}$ & $1789-0$ & $q$ & $1815-6$ & $\mathbf{Z K}$ & 1841-2 & $\mathbf{R}$ & $1866-7$ \\
\hline $\mathrm{R}$ & $1790-1$ & $\mathbf{r}$ & $1816-7$ & 5 & $1842-3$ & $\mathrm{~S}$ & $1867-8$ \\
\hline S & $1791-2$ & $S$ & $1817-8$ & $\boldsymbol{U}$ & $1843-4$ & $\mathrm{~T}$ & $1868-9$ \\
\hline $\mathrm{T}$ & $1792-3$ & $t$ & $1818-9$ & 2 & $1844-5$ & $\mathrm{U}$ & $1869-0$ \\
\hline $\mathrm{U}$ & $1793-4$ & $\mathrm{u}$ & $1819-0$ & $\mathbb{0}$ & $1845-6$ & $\mathrm{~V}$ & $1870-1$ \\
\hline $\mathrm{V}$ & $1794-5$ & V & $1820-1$ & ชช & $1846-7$ & W & $1871-2$ \\
\hline W & $1795-6$ & W & $1821-2$ & $x$ & $1847-8$ & $\mathrm{X}$ & $1872-3$ \\
\hline $\mathrm{X}$ & $1796-7$ & $\mathrm{x}$ & $1822-3$ & 温 & $1848-9$ & $Y$ & $1873-4$ \\
\hline $\mathbf{Y}$ & $1797-8$ & $\mathrm{y}$ & $1823-4$ & 2 & $1849-0$ & Z & $1874-5$ \\
\hline Z & $1798-9$ & $\mathrm{Z}$ & $1824-5$ & & & & \\
\hline \multicolumn{2}{|c|}{$\begin{array}{l}\text { FIvE Stamps. } \\
\text { 1. Anchor. } \\
\text { 2. Lion passant. } \\
\text { 3. Date Mark. } \\
\text { 4. Sovereign's Head, } \\
\text { 1784. } \\
\text { 5. Maker's Initials. }\end{array}$} & \multicolumn{2}{|c|}{$\begin{array}{l}\text { FIVE STAMPS. } \\
\text { 1. Anchor. } \\
\text { 2. Lion passant. } \\
\text { 3. Date Mark. } \\
\text { 4. Sovereign's Head. } \\
\text { 5. Maker's Initials. }\end{array}$} & \multicolumn{2}{|c|}{$\begin{array}{l}\text { Five STAMPS. } \\
\text { 1. Anchor. } \\
\text { 2. Iion passant. } \\
\text { 3. Date Mark. } \\
\text { 4. Sovereign's Head. } \\
\text { 5. Maker's Initials. }\end{array}$} & \multicolumn{2}{|c|}{$\begin{array}{l}\text { FIVE STAMPS. } \\
\text { 1. Anchor. } \\
\text { 2. Lion passant. } \\
\text { 3. Date Mark. } \\
\text { 4. Queen's Head. } \\
\text { 5. Maker's Initials. }\end{array}$} \\
\hline
\end{tabular}

Note.-For the new standard of $11 \mathrm{oz} .10 \mathrm{dwts}$. a stamp of Britannia is used instead of the Lion passant. 
SHEFFIELD ASSAY OFFICE LETTERS.

\begin{tabular}{|c|c|c|c|c|c|c|c|c|c|}
\hline \multicolumn{2}{|c|}{ CYCLE 1.} & \multicolumn{2}{|c|}{ CYCLE 2.} & \multicolumn{2}{|c|}{ CYCLE 3.} & \multicolumn{2}{|c|}{ CYCLE 4.} & \multicolumn{2}{|c|}{ CYCLE 5.} \\
\hline (iv) & $1773-4$ & (6) & $1799-0$ & ta & $1824-5$ & Aft? & $1844-5$ & & $1868-9$ \\
\hline Jt & $1774-5$ & $\mathrm{~N}$ & $1800-1$ & b & $1825-6$ & B & $1845-6$ & B & $1869-0$ \\
\hline 112 & $1775-6$ & $\mathrm{H}$ & $1801-2$ & c & $1826-7$ & $\mathrm{C}$ & $1846-7$ & $\mathrm{C}$ & $1870-1$ \\
\hline BR & $1776-7$ & M & 1802-3 & d & 1827.8 & D & $1847-8$ & D & 1871.2 \\
\hline ll & $1777-8$ & $\mathrm{~F}$ & $1803-4$ & e & $1828-9$ & $\mathrm{E}$ & $1848-9$ & $\mathbf{E}$ & $1872-3$ \\
\hline 5 & $1778-9$ & G & $1804-5$ & $f$ & $1829-0$ & $\mathrm{~F}$ & $1849-0$ & $\mathbf{F}$ & 1873.4 \\
\hline I & $1779-0$ & $B$ & 1805.6 & $0^{\circ}$ & $1830-1$ & $G$ & $1850-1$ & G & $1874-5$ \\
\hline (1) & $1780-1$ & A & $1806-7$ & 8 & & $\mathrm{H}$ & $1851-2$ & & $1875-6$ \\
\hline 䏣 & 1781.2 & $\mathrm{~S}$ & $1807-8$ & 1- & $1831-2$ & I & $1852-3$ & & 1876 \\
\hline (16) & $1782-3$ & $\mathrm{P}$ & $1808-9$ & K & 1832-3 & $\mathrm{K}$ & $100 \pi$ & & 1080.6 \\
\hline $1 \mathrm{~B}$ & $1783-4$ & $T /$ & & 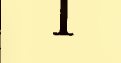 & $1833-4$ & & $1000-4$ & & $1877-8$ \\
\hline$\tilde{3}$ & $1784-5$ & & $1009-0$ & $\mathrm{~m}$ & $1834-5$ & & $1854-5$ & & $1878-9$ \\
\hline 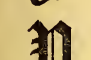 & $1785-6$ & L & & p & $1835-6$ & IVI & $1855-6$ & M & $1879-0$ \\
\hline & $1800-0$ & U & $1811-2$ & O & $1836-7$ & $\mathrm{~N}$ & $1856-7$ & $\mathbf{N}$ & $1880-1$ \\
\hline & $1786-7$ & D & $1812-3$ & & $1000-6$ & O. & $1857-8$ & 0 & $1881 \cdot 2$ \\
\hline 1 & $1787-8$ & $\mathrm{R}$ & $1813-4$ & $\mathbf{I}$ & $1837-8$ & $\mathrm{P}$ & $1858-9$ & $\mathbf{P}$ & $1882-3$ \\
\hline बब. & $1788-9$ & W & $1814-5$ & $\mathbf{S}$ & $1838-9$ & $\mathbf{R}$ & $1859-0$ & $Q$ & $1883-4$ \\
\hline (1) & $1789-0$ & 0 & 1815.6 & $t$ & $1839-0$ & $\mathrm{~S}$ & $1860-1$ & R & 18845 \\
\hline \pm & $1790-1$ & $\mathrm{~T}$ & & $\mathbf{u}$ & $1840-1$ & $\mathrm{~T}$ & ? 1861 & r & U1004-0 \\
\hline 1 & $1791-2$ & $\mathrm{X}$ & & V & $1841-2$ & TT & $1001-2$ & & $0-6$ \\
\hline वा & 1792-3 & $T$ & & $\mathbf{X}$ & 1842-3 & $\mathrm{V}$ & & & $1886-7$ \\
\hline (1) & $1793-4$ & $\mathrm{~T}$ & & $\mathbf{Z}$ & $1843-4$ & W & $1863-4$ & & $1887-8$ \\
\hline GA & $1794-5$ & 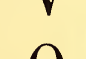 & $1819-0$ & & & pr & $1864-5$ & & $1888-9$ \\
\hline (1) & 18016 & $Q$ & $1820-1$ & & & X & $1865-6$ & W & $1889-0$ \\
\hline U⿺辶 & $1690-0$ & $\mathrm{Y}$ & $1821-2$ & & & $Y$ & $1866-7$ & $X$ & $1890-1$ \\
\hline I/ & $1790-6$ & Z & 1822-3 & & & $Z$ & $1867-8$ & $Y$ & $1891-2$ \\
\hline & $1797-8$ & $\mathrm{U}$ & $1823-4$ & & & & & $z$ & 1892-3 \\
\hline 11 & $1798-9$ & & & & & & & & \\
\hline $\begin{array}{l}\text { 1. } \mathrm{Li} \\
\text { 2. } \mathrm{C} \\
\text { 3. } \mathrm{D} \\
\text { 4. } \mathrm{D} \\
\text { 5. } \mathrm{M}\end{array}$ & $\begin{array}{l}\text { n passant. } \\
\text { wn. } \\
\text { el letter. } \\
\text { ty, King ', shead } \\
\text { ker's Mark. }\end{array}$ & $\begin{array}{l}\text { 1. } \mathrm{Li} \\
\text { 2. } \mathrm{Cr} \\
\text { in } \\
\text { 3. } \mathrm{Di} \\
\text { 4. } \mathrm{M}_{\text {s }}\end{array}$ & $\begin{array}{l}\text { passant. } \\
\text { van and date } \\
\text { ne stamp. } \\
\text { y. }\end{array}$ & $\begin{array}{l}\text { 1. Lion } \\
\text { 2. Crow } \\
\text { 3. Duty } \\
\text { 4. Make }\end{array}$ & ssant. & $\begin{array}{l}\text { 1. Lion } \\
\text { 2. Crov } \\
\text { 3. Dut } \\
\text { 4. Mak }\end{array}$ & $\begin{array}{l}\text { passant. } \\
\text { nand date. } \\
\text { r. }\end{array}$ & & $\begin{array}{l}\text { passant. } \\
\text { nn. } \\
\text { letter. } \\
\text { er. }\end{array}$ \\
\hline
\end{tabular}




\title{
SC OTLAND.
}

\section{EXTRACTS FROM STATUTES AND ORDINANCES,}

\author{
WITH EXPLANATORY NOTES.
}

In the reign of James II. A.D. 1457, a statute was passed for " the reformation of gold and silver wrought by Goldsmiths, and to eschew the deceiving done to the King's lieges, there shall be ordained in each Burgh where Goldsmiths work, one understanding and cunning man of good conscience, who shall be deacon of the craft; and when work is brought to the Goldsmith and it be gold, he shall give it forth again in work, no worse than twenty grains and silver eleven grains fine, and he shall take his work to the deacon of the craft that he may examine that it be fine as above written, and the said deacon shall set his mark and token thereto, together with the said Goldsmith's ; and when there is no Goldsmith but one in the town he shall show that work tokened with his own mark, to the head officers of the town which shall have a mark in like manner ordained therefore, and shall be set to the said work."”

In 1473, it was enacted that places were to be appointed in Scotland wherein goldsmiths should examine the gold, and when sufficient "set their marks thereto."

In the records of the Town Council of the year 1483, we read that the goldsmiths, with other trades, under the general title of Hammermen, presented a petition complaining of certain irregularities :-

"IN THE FIRST thair complaint bure and specifyit that thay war rycht havely hurt and put to great poverty throw the douncumming of the blak money, walking, warding and in the payment of yeldis and extentis quhilkis thay war compellit to do be use.

"And in lykwyis that thai were havely hurt be the dayly mercat maid throw the hie street in cramis and on the baksyde the toun in haichling and hammermennis werk pertaining to thame of thair craft in greit dishonour to the burgh and in braking of the auld gude rule and statutis of thair craft and upor. uther skathis that thay sustenit in defalt of reformatioun." 
Whereupon it was ordered there should be no "oppin mercat usit of ony of the saidis craftis upon the hie streittis nor in cramis upon buirdis," \&c. " That upoun ilk Settirday eftir none tua or thrie of the worthiest maisters and maist of knowledge of the said craftis, quhilk sall haif powar with ane officiar with thame to pas serch and se all mennis work gif it be sufficient in stuff and workmanschip, gude worth and hable work to serve the Kingis liegis with and quhair it beis fundin faultive to forbid the samyn to be sauld under the paine of escheitt."

In the reign of James III., 1483, also it is advised and concluded by the Lords of the Articles, " That henceforth there be in each burgh of the realm where goldsmiths are, one deacon and one searcher of the craft, and that each goldsmith's work be marked with his own mark, the deacon's mark, and the mark of the town, silver of the fineness of eleven penny fine, and gold of twenty-two carats fine."

In 1849, another statute to the same effect was ordained; by this, each goldsmith was to have one special mark, his works were to be of the fineness of the new works of silver of Bruges, and there was to be a deacon of the craft, who was to examine and mark the works.

In 1555, "Forasmuch as there is great fraud, \&c., it is ordained that no goldsmith make in work nor set forth either his own or other men's silver, under the just fineness of eleven penny fine under the pain of death and confiscation of all their goods and moveables; and that every goldsmith mark the silver work with his own mark, and with the town's mark; also that no goldsmith set forth either his own or other men's gold, under the just fineness of 22 carats fine, under the pain aforesaid."

Letters under the Privy Seal by King James VI. in favour of the Deacon and Maisteris of the Goldsmyth Craft, Jany. 3, 1586, which empowered them to search for gold and silver, and to try whether it were of the fineness required by former Acts of Parliament, and seize such as should be deficient. That it shall not be lawful for any except the masters of the craft to melt any gold or silver work unless it be first shown to them to see whether it has been stolen (the libertie of our Soveraine Lordis cunyiehous alwyis exceptit.) 
Act and Statute of the Town Council of Edinburgh, in favour of the Corporation of Goldsmyths, Aug. 20, 1591.

"The samin day the Provost baillies and counsell, and Adame Newtoune, baxter, Cudbert Cranstoun, furrour, William Blythman, flescheour, Thomas Weir, masoun, Robert Meid, wobster, William Cowts, walker, Thomas Brown, bonetmaker, of the remanent deykins of crafts being convenit in counsall anent the supplicatioun gevin in before thame be George Heriott, deykin of the goldsmythis, for himselff and in name and behalff of the remannet brether of the said craft."

The tenour of these articles which were agreed to, referred to the taking of apprentices for a term of seven years, that every master shall have served his apprenticeship, and three years over and above, to make himself more perfect therein, and have given proof to the deacon of the craft of his experience, both in workmanship and knowledge of the fineness of the metals, \&c.

Only those admitted by the deacon and masters were to work, melt, or break down, or sell any gold or silver work, under penalty of twenty pounds, or imprisonment.

That no goldsmith melt any work without first showing it to the deacon to see whether it was stolen, nor gild any lattoun or copper work.

By the foregoing enactments it will be seen that only three marks are referred to, namely:-the Goldsmith's mark, the Deacon's mark, and the Town mark-the first was the initials of the maker's name, the second the initials of the deacon's name, and the third the castle, indicating the City of Edinburgh-and nothing is said about a variable letter. The first mention of it we find in the Minutes of the Goldsmiths' Company, is in September, 1681, when a small black letter $\mathbb{a}$ was ordered to be the letter for the ensuing year; after this the letter is ordered annually in alphabetical order, from $\mathrm{A}$ to $\mathrm{Z}$, in cycles of twentyfive years. In many cases the letter is stamped at the top of the page with the identical punch used for the plate.

The Charter of King James VII., incorporating the Society of Goldsmiths of Edinburgh, dated 10 November, 1687, ratifies the letters patent of James VI., of the 3 Jany. 1586, in every respect, and amplifies their power in many instances, such as granting them the privilege of an Incorporated Society, with power to acquire, purchase and possess lands, \&c., enact statutes and laws for the regulation of the trade, \&c. 
"And because the art and science of goldsmiths, for the most part, is exercised in the City of Edinburgh, to which our subjects frequently resort, because it is the seat of our supreme Parliament, and of the other supreme courts, and there are few goldsmiths in other cities; Therefore we by these presents give and grant to the said deacon "and masters, full power, faculty and authority to investigate, inquire into and examine the gold or silver work, and all gems and stones set in gold or silver, or made and wrought in any other city, royal burgh, or barony, market, or fair, or exposed to sale any where within our said kingdom," \&c.

We have no evidence of any plate being marked in Scotland, but at the Goldsmiths' Hall, Edinburgh, until Glasgow had the privilege of doing so, in May, 1819.

The first entry in the books of the Goldsmiths' Company of Edinburgh where the thistle is noticed is in the year 1759, and after that date, for about twenty years, the minutes year by year particularly name the thistle to be used (instead of the assay master's initials) along with the letter for the year.

The statute $6 \& 7$ of Wm. IV. 1836-7, is entitled " An Act to fix the standard qualities of gold and silver plate in Scotland, and to provide for the assaying and marking thereof." The marks required by this Act are-

For gold of 22 carats-1. The maker's initials. 2. The thistle. 3. The mark of the city. 4. The variable letter. 5. The duty mark of the sovereign's head.

For gold of 18 carats, the same, with the additional stamp of a crown and 18.

For silver of the old standard of $11 \mathrm{oz} .2$ dwts., the same as for gold of 22 carats. For silver of the new standard of $11 \mathrm{oz} .10 \mathrm{dwts}$. the same stamps, with the additional mark of Britannia.

The duty on plate and licenses is the same as in .England, the payment of which is denoted by the sovereign's head since the passing of the act in 1784 .

The accompanying Table is arranged from the minutes of the Goldsmiths' Company of Edinburgh, where the date letters appear noted almost every year from 1681, verified by pieces of plate bearing dates. The goldsmith's year is from. Michaelmas to Michaelmas (29 Sept.) The hall mark or town mark of a castle was used as early as in 1457, and is referred to in that Act (before quoted,) and alluded to again in 1483 and 1555. 
Previous to 1681, when our table commences, no date mark appears to have been used. On a piece of plate said to be of the sixteenth century, exhibited at Edinburgh in 1856, in the Museum of the Archæological Institute, we find a castle (the middle tower higher than the two others, as usual), and two other stamps of the letter E. These are, perhaps, the town mark, assay master's, and maker's mark. The silver mace belonging to the City of Edinburgh, and known from the town records to have been made by George Robertson in 1617, has three marks, viz., the castle, the cipher G. R., and the letter G.

The High Church plate, dated 1643, and the Newbattle Church plate, dated 1646, and several others of the same date, have only the town mark, the assay master's mark, and that of the maker.

CrCLE 1 has an old English small letter from A to Z, omitting $J$ and $U$, in all 24 letters, all given in the minutes. There were thus 4 stamps used instead of 3 , as formerly, and in 1697 the figure of Britannia for the new standard was added.

Cycle 2 has Roman capitals from A to Z, omitting the letter $J$ only, viz., 25 letters. In 1720 the figure of Britannia was omitted.

Crcle 3. Italic capitals, 25 letters.

Cycle 4. Black letter capitals, 25 letters, but the J. and W. being omitted, another sign of " \&" is added to make up the number. In the year 1759 the standard mark of a thistle was introduced instead of the assay master's initials, which change was noted in the minutes. These marks are verified by pieces of a service, called the "Cluny plate," all of one pattern, and made by the same maker in various years.

Cycle 5. Roman capitals, commencing with A in 1780, and finishing with $\mathrm{Z}$ in 1805 . In 1784 the duty mark of the sovereign's head was introduced, and the letter G is repeated in 1787, making 26 letters, the $\mathrm{J}$ being omitted.

Cxcle 6. Small Roman letters, from a 1806 to z 1831, including the letter $\mathrm{j}$, in all 26.

Crcle 7. Black letter capitals; again omitting the $\mathrm{J}$, we have 25 letters.

Cycle 8. Egyptian, or black capitals. 
I.-The Standard.

For Edinburgh-A Thistue (after 1759). For Glasgow-A Lion Rampant.

$$
\text { II.-The HaLl Mark. }
$$

For Edinburgh-A CASTLE.

For Glasgow-A Tree, a Fish and Bell.

$$
\text { III.-The Duty Mark. }
$$

The Sovereign's Head, indicating payment of the duty of $17 \mathrm{~s}$. per oz. on gold, and 1s. 6d. per oz. on silver.

$$
\text { IV.-The Date Mark. }
$$

A Letter of the Alphabet. The custom has been to use the letters alphabetically from $\mathrm{A}$ to $\mathrm{Z}$, omitting $\mathrm{J}$, thus making a cycle of 25 years (with some exceptions).

$$
\text { V.-The Maker's Name. }
$$

Formerly some device, with or without his initials; afterwards the initials of his christian and surname. 
EDINBURGH ASSAY OFFICE LETTERS.

\begin{tabular}{|c|c|c|c|c|c|c|c|}
\hline \multicolumn{2}{|c|}{$\begin{array}{l}\text { CYCLE } 1 . \\
\text { BLACK LetTer SMALL. }\end{array}$} & \multicolumn{2}{|c|}{$\begin{array}{c}\text { CYCLE } 2 . \\
\text { Roman Capitals. }\end{array}$} & \multicolumn{2}{|c|}{$\begin{array}{c}\text { CYCLE } 3 . \\
\text { Italic Capitals. }\end{array}$} & \multicolumn{2}{|c|}{$\begin{array}{l}\text { CYCLE } 4 . \\
\text { OLd ENGLISH CAPS. }\end{array}$} \\
\hline & $\begin{array}{l}\text { 29th Sept. } \\
\text { CHARLES II. } \\
1681-2\end{array}$ & & $\begin{array}{l}29 \text { th Sept. } \\
1705-6\end{array}$ & $\mathscr{A}$ & $\begin{array}{c}\text { 29th Sept. } \\
1730-1\end{array}$ & Q & $\begin{array}{l}\text { 29th Sept. } \\
1755-6\end{array}$ \\
\hline & $1682-3$ & & $1706-7$ & $\mathscr{B}$ & & & $1756-7$ \\
\hline & $1683-4$ & & $1707-8$ & $\mathscr{C}$ & $1732-3$ & & \\
\hline & & & & $\mathscr{D}$ & & & \\
\hline & & & & & & & $160-9$ \\
\hline & $1685-6$ & & $1709-0$ & 6 & $1734-5$ & & $1759-0$ \\
\hline & $1686-7$ & & $1710-1$ & $\mathscr{O}$ & $1735-6$ & & $\begin{array}{l}\text { GEORGE III. } \\
1760-1\end{array}$ \\
\hline & $1687-8$ & & $1711-2$ & $\mathscr{E}$ & $1736-7$ & & $1761-2$ \\
\hline & $\begin{array}{l}\text { WILLL. \& MARY. } \\
1688-9\end{array}$ & & $1712-3$ & & $1737-8$ & & 1762.3 \\
\hline & - $1689-0$ & & $1713-4$ & & 1738.9 & & $1763-4$ \\
\hline & 1690-1 & & $\begin{array}{l}\text { GEORGE } . \\
1714-5\end{array}$ & 10 & $1739-0$ & & $1764-5$ \\
\hline & 1691-2 & & $1715-6$ & & $1740-1$ & & $1765-6$ \\
\hline & 1692-3 & & $1716-7$ & 16 & $1741-2$ & & $1766-7$ \\
\hline & $1693-4$ & & 1717.8 & $\mathscr{A}$ & $1742-3$ & & $1767-8$ \\
\hline & $1694-5$ & & $1718-9$ & 0 & $1743-4$ & & $1768-9$ \\
\hline & $\begin{array}{l}\text { WILLIA } \\
169\end{array}$ & & $1719-0$ & & $1744-5$ & & $1769-0$ \\
\hline & $1696-7$ & & $1720-1$ & $\mathscr{4}$ & $1745-6$ & & $1770-1$ \\
\hline & $1697-8$ & & $1721-2$ & कृ & $1746-7$ & & $1771-2$ \\
\hline & 1698-9 & & 1722-3 & & $1747-8$ & & $1772-3$ \\
\hline & 1699-0 & & $1723-4$ & $\mathscr{J}$ & $1748-\dot{9}$ & & $1773-4$ \\
\hline & $1700-1$ & & $1724-5$ & 26 & $1749-0$ & & $1774-5$ \\
\hline & $1701-2$ & & $1725-6$ & $\mathscr{Q}$ & $1750-1$ & & $1775-6$ \\
\hline & $\begin{array}{l}\text { ANNE. } \\
1702-3\end{array}$ & & 1726.7 & 20 & $1751-2$ & & $1776-7$ \\
\hline 10 & $1703-4$ & & $\begin{array}{l}\text { GEORGE II. } \\
1727-8\end{array}$ & & $1752-3$ & & $1777-8$ \\
\hline 3 & $1704-5$ & & 1728-9 & & $1753-4$ & & $1778-9$ \\
\hline & & & $1729-0$ & & $1754-5$ & & 1779.0 \\
\hline $\begin{array}{l}\text { For } \\
\text { 1. The } \\
\text { 2. The } \\
\text { Ini } \\
\text { 3. The } \\
\text { 4. The } \\
\text { pois }\end{array}$ & $\begin{array}{l}\text { STAMPS. } \\
\text { astle. } \\
\text { ssay Master's } \\
\text { lls. } \\
\text { aker's Initials. } \\
\text { ate Letter in a } \\
\text { d shield. }\end{array}$ & $\begin{array}{l}\text { Fo } \\
\text { 1. The } \\
\text { 2. The } \\
\text { 3. The } \\
\text { 4. The } \\
\text { poi }\end{array}$ & $\begin{array}{l}\text { STAMPS. } \\
\text { astle. } \\
\text { ssay Mark. } \\
\text { aker's Initials. } \\
\text { ate Letter in a } \\
\text { d shield. }\end{array}$ & $\begin{array}{l}\text { Fou } \\
\text { 1. The } \\
\text { 2. The } \\
\text { 3. The I } \\
\text { 4. The . } \\
\text { squa }\end{array}$ & $\begin{array}{l}\text { STaMPs. } \\
\text { astle. } \\
\text { ssay Mark. } \\
\text { aker's Initials. } \\
\text { te Letter in a } \\
\text { shield. }\end{array}$ & $\begin{array}{l}\text { Fc } \\
\text { 1. The } \\
\text { 2. The } \\
\text { 3. The } \\
\text { 4. The } \\
\text { sql }\end{array}$ & $\begin{array}{l}\text { STAMPS. } \\
\text { stle. } \\
\text { istle, in } 1759 . \\
\text { ker's Initials. } \\
\text { te Letter in a } \\
\text { shield. }\end{array}$ \\
\hline
\end{tabular}

From 1697 to 1720 Britannia was added for the new standard.

* The standard mark of a thistle was used instead of the Assay Master's initials in 1759, by a Minute of the Corporation. 


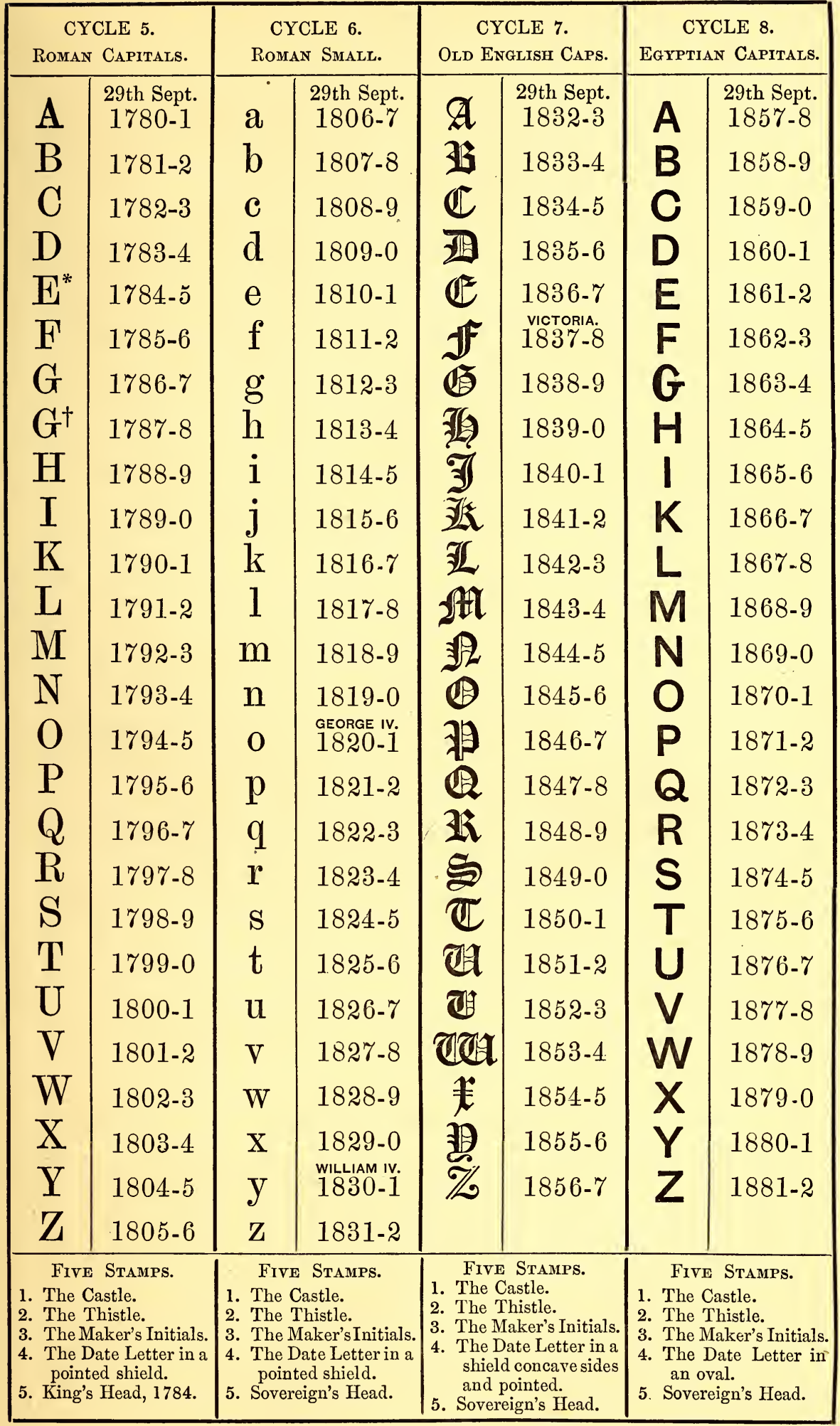

* In 1784 the Duty Mark of the Sovereign's Head was added.

† The $G$ is repeated, according to the Minutes. 


\section{GLASGOW.}

Glasgow was made an assay town by the 59 Geo. III. (May, 1819). The district comprised Glasgow and forty miles round, and it was directed that all plate made in the district should be assayed at that office.

The peculiar mark of the Company is a tree growing out of a mount, with a bell pendent on the sinister branch, and a bird on the top branch, over the trunk of the tree a salmon in fesse, in its mouth an annulet.

The Marks used on plate stamped at Glasgow are-

1. The standard, a lion rampant.

2. The hall mark, the arms of the city, as described above.

3. The maker's mark, viz., his initials.

4. The date mark, or variable letter, changed on the 1st July in every year.

5. The duty mart of the sovereign's head.

For gold of 18 carats the figures 18 are added, and for silver of the new standard, Britannia, instead of the lion rampant.

The Scotch Act of $6 \& 7 \mathrm{Wm}$. IV. 1836-7, in some respects extended to Glasgow, although it is generally regulated by the 59th of Geo. III. ; but they have not adopted the marks prescribed by this statute of 1836, and continue those previously in use, the only difference however is, that the lion rampant takes the place of the thistle.

Other Towns in Scotland seem to have availed themselves of the early Acts of Parliament, and used their own Town marks.Both Perth and St. Andrews had their Town marks, the former a spread eagle, the latter a St. Andrew's cross, and examples of these are still in existence. That of Perth on the West Church plate in 1771, along with all the Edinburgh marks of that date, and that of St. Andrew's on the Parish Church plate, bearing date 1671. 
GLASGOW ASSAY OFFICE LETTERS.

\begin{tabular}{|c|c|c|c|c|c|c|c|}
\hline$A$ & $\begin{array}{l}\text { 1st July. } \\
1819-0\end{array}$ & $\mathbf{N}$ & $\begin{array}{l}\text { 1st July } \\
1832-3\end{array}$ & 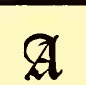 & $\begin{array}{l}\text { 1st July. } \\
1845-6\end{array}$ & $=2$ & $\begin{array}{l}\text { 1st July. } \\
1858-9\end{array}$ \\
\hline & $1820-1$ & & $1833-4$ & $\mathfrak{B}$ & $1846-7$ & $\mathbb{B}$ & $1859-0$ \\
\hline & $1821-2$ & & $1834-5$ & $\mathbb{C}$ & $1847-8$ & 羽 & $1860-1$ \\
\hline & $1822-3$ & & $1835-6$ & 2 & $1848-9$ & $\mathbb{2}$ & $1861-2$ \\
\hline & $1823-4$ & U & $1836-7$ & $\mathbb{E}$ & $1849-0$ & $3 \mathfrak{R}$ & 1862-3 \\
\hline & $1824-5$ & & $1837-8$ & If & $1850-1$ & 5 & $1863-4$ \\
\hline & $1825-6$ & & $1838-9$ & 6 & $1851-2$ & $\mathbb{T}$ & $1864-5$ \\
\hline & $1826-7$ & & $1839-0$ & 3 & $1852-3$ & 约 & $1865-6$ \\
\hline & $1827-8$ & & $1840-1$ & $\mathfrak{3}$ & $1853-4$ & $\boldsymbol{d}$ & $1866-7$ \\
\hline & $1828-9$ & $\mathbf{W}$ & $1841-2$ & उ్త] & $1854-5$ & ช্য & $1867-8$ \\
\hline & $1829-0$ & $X$ & $1842-3$ & 逊 & $1855-6$ & 拝 & $1868-9$ \\
\hline & $1830-1$ & $\mathbf{Y}$ & $1843-4$ & 站 & $1856-7$ & 㫜 & $1869-0$ \\
\hline $\mathrm{M}$ & 1831-2 & 7 & $1844-5$ & $\mathbb{f H}$ & $1857-8$ & $\mathscr{H}$ & $1870-1$ \\
\hline & \multicolumn{3}{|c|}{$\begin{array}{l}\text { Five STaMrPs. } \\
\text { 1. Lion rampant. } \\
\text { 2. Tree, Fish, and Bell. } \\
\text { 3. Sovereign's Head. } \\
\text { 4. Date Letter. } \\
\text { 5. Maker's Initials. }\end{array}$} & \multicolumn{4}{|c|}{$\begin{array}{l}\text { FIVE Stamps. } \\
\text { 1. Lion rampant. } \\
\text { 2. True, Fish, and Bell } \\
\text { 3. Queen's Head. } \\
\text { 4. Date Letter. } \\
\text { 5. Maker's Initials. }\end{array}$} \\
\hline
\end{tabular}




\section{R E L A N D.}

The Goldsmiths' Company in Dublin, has the exclusive management of the assaying and marking of wrought gold and silver plate in Ireland.

The harp, and subsequently the harp crowned, was the original hall or district mark for all Irish manufactured plate assayed in Dublin, and found to be standard, and was used long previous to the charter granted by Charles I., 22 December, in the year 1638, in the thirteenth year of his reign, to the Corporation of Goldsmiths of Dublin, Ireland. This charter adopted for Ireland the standards then in use in England, viz.-22 carats for gold, and 11 oz. 2 dwts. for silver. The harp crowned has been continued in use ever since, in pursuance of a clause contained in that charter, and also by the Act $23 \&$ 24 Geo. III. c. 23, s. 3, 1784.

The figure of Hibernia was used by order of the Commissioners of Excise in the year 1730, when a duty was first imposed, to denote the payment of the duty, viz.- sixpence per ounce on manufactures of silver plate, and at eight shillings per ounce on gold plate.

The King's head, or the head of the reigning sovereign, is affixed to denote the payment of the duty, by the 47 Geo. III., Sess. 2, c. 15, s. 6, 10 August, 1807, in which Act no notice was taken of the former mark of Hibernia, and the two marks were continued.

In the year 1784 a Company of Geneva Watch Makers came to Ireland, and commenced an establishment near Waterford, in the County of Waterford, and the place or locality of this establishment was called New Geneva. An Assay Office, and a deputy assay-master or assayer were granted to them at that place, under the provisions of the $23 \& 24$ Geo. III. c. 23. This Act came into operation on the 1st June, 1784, and repeals so much of the 3rd of Geo. II. as respects the assaying of gold, or regulating the manufacture, assaying or exchange or sale of gold, or the duty on any manufacture of gold in Ireland. The only standard of gold 
allowed by the Act 3 Geo. II. was that of 22 carat fine; this was altered by the $23 \& 24$ Geo. III. c. 23 , whereby three standards are provided of 22,20 , and 18 carats fine, respectively. These standards were authorized by this Act to facilitate and encourage the manufacture of gold and silver wares and watch cases, \&c., \&c., in Ireland, and especially at New Geneva.

This establishment and assay office did not continue to work over five or six years, and with this exception the Assay Office in Dublin has been, and is, the only one in Ireland, and has power and jurisdiction in all parts of Ireland.

The Marks directed by this Act are :-

1. Standard Gold of 22 carats.-The figures 22 and the initials of the christian and surnames of the maker, and the harp crowned, if stamped in the Assay Office in Dublin-or the harp crowned, with a bar across the harp strings, if stamped in the Assay Office at New Geneva, Waterford.

2. Standard Gold of 20 carats.-The figures 20, and the initials of the christian and surnames of the maker, and a plume of three feathers, if stamped in the Assay Office in Dublin-or a plume of two feathers, if stamped in the Assay Office at New Geneva, Waterford.

3. Standard Gold of 18 carats.-The figures 18, and the initials of the christian and surnames of the maker, and an unicorn's head, if stamped in the Assay Office in Dublin-or the unicorn's head with a collar on the neck, if stamped in the Assay Office at New Geneva, Waterford.

For description of articles that are exempted from duty and marking by this Act, see Sec. 6 .

By the 11th sec. of this Act (23 \& 24 Geo. III. c. 23) it is enacted, "That on and after the 1st June, 1784, every person making, or causing to be made, any manufactures of gold, are to enter an impression of his or her new marks or punches made as aforesaid, with his or her name and place of abode, in either of the said Assay Offices, upon paying the sum of five shillings to the assayer or wardens, who are hereby required to make, on a plate of pewter or copper, impressions of such marks or punches; and also entries of such marks or punches, with the names and places of abode of the owners thereof, in a book or books to be carefully kept for that purpose, if such owners be resident in Dublin, or at New Geneva. And that no person or persons 
shall be entitled to have any manufactures of gold made, or caused to be made by him or her, assayed or stamped, at either of the said assay offices, until after same have been stamped by the maker, and until after such impression and entry have been made at such office of the mark or punch of said person or persons, which denotes the particular standard of such manufactures of gold; and that no manufacture of gold shall be assayed or stamped at the said Assay Offices, if marked with any other mark or punch but such as is duly entered; and that no manufacture of gold shall be assayed or stamped at said Assay Offices unless such gold work be marked with the mark which denotes the true standard of same."

The maker's marks were in use, and were also registered, at the time of the passing of this Act, and for many years previously, in accordance with other Acts of Parliament, and the practice of the London Hall. The manufacturers were required to stamp and register their mark punches in the Assay Office in Dublin, previous to the year 1694, and this practice has been continued to the present time.

These three standards of 22,20 , and 18 carats, directed by this Act, were continued by another Act, subsequently passed, namely, the 47 Geo. III., Sess. 2, c. 15, s. 3, 10 August, 1807, and are still in use.

In addition to these, three lower standards of 15,12 , and 9 carats, are also provided by the $17 \& 18$ Vict. from and after the 22nd December, 1854, for gold wares-these standards are subject to duty, assaying, and marking with the usual marks, and the figures 15,12 , or 9 , to denote the true standard of same.

By the 5 \& 6 Vict. c. 47, s. 59-60, the several Assay Offices in the United Kingdom of Great Britain and Ireland, are directed and empowered to assay and mark Foreign manufactured gold and silver plate; and also to assay and mark, at any of the said Assay Offices, gold and silver plate manufactured in any part of the said United Kingdom of Great Britain and Ireland.

Previous to the passing of this Act, each of the Assay Offices had power only to assay and mark gold and silver plate manufactured within their own districts.

N.B.-The mark punch of the resident shopkeeper, or importer of plate, is required to be registered, in respect of assaying and marking Foreign plate, or plate manufactured out of the district 
of the Assay Office that it is sent to be assayed; but the maker's marks are not required unless he is resident in the city, or town, or district of the assay.

The variable letter of the year is the date mark, and is impressed on all manufactured gold and silver plate that is stamped at the Assay Office in Dublin, in accordance with the practice of the Goldsmith's Hall in London, but the letter, and also the character of the letter, used in Dublin in each year, is not the same as is used in London, in each corresponding year. Thus, for example, the London date mark in the year 1860-61, was the letter ( $(\mathfrak{l})$ old English small, and the Dublin date mark, in the same year, was the letter (p) Roman small. The Dublin alphabet, ending with the letter (Z) on the 29th or 30th day of May, 1821, was in Roman capitals; the character of the letter was then changed for Roman small, commencing with the letter (a), and was continued with the succeeding letters annually, in the same character, until about the 30th day of September, 1825, when the small Roman letter (e) was changed, and Roman capitals again used, beginning with (E); this was done in compliance with the order of the Commissioners of Stamps, to denote the transfer of the duty from the Commissioners and Collectors of Excise to the Commissioners of Stamps, by the Act 6 Geo. IV. c. 118 : and also to mark the change of the standard of silver made in Ireland at that time, by having to adopt the practice of the London Hall in marking silver plate, at an allowance of only one pennyweight and a half below the standard-this was also by order of the Commissioners of Stamps, and according to the 47 Geo. III. c. 15, Sess. 2. Previous to this order, Irish manufactured silver plate used to be marked in Dublin, at some periods, as standard, at an allowance of from two and a half to three and a half pennyweight worse than the standard, consequently Irish sterling, manufactured previous to the 13th August, 1825, was inferior to English sterling, and to the Irish sterling subsequently manufactured.

The date mark has been used in Dublin from a very early period, as it appears to have been in use previous to the year 1646 . 


\section{IRELAND.}

\section{I.-The StANDARD.}

For Dublin.-A harp Crowned for gold of 22 carats, and silver of $11 \mathrm{oz} .2 \mathrm{dwts}$.

For gold of 22 carats-A HARP CROWNED AND THE FIGURES 22 ; 23, 24, Geo. III. (1784).

For gold of 20 carats-A PLUME OF THREE FEATHERS AND 20. (1 June, 1784).

For gold of 18 carats-An UNICORN'S HEAD AND THE FIGURES 18. (1 June, 1784).

In addition to these, three lower standards of 15,12 , and 9 carats, are provided by the $17 \& 18$ Vict., on and after 22 nd December, 1854, for gold wares.

For New Geneva (from the 1st June, 1784, which lasted five or six years).

For gold of 22 carats - A HARP CrownEd AND ERASED (a bar across) AND THE FIGURES 22.

For gold of 20 carats-A PLUME OF TWO FEATHERS AND THE FIGURES 20.

For gold of 18 carats-AN UNICORN's HEAD WITH COLLAR AND THE FIGURES 18.

$$
\text { II.-The Hali Mark. }
$$

For Dublin-A figure of Hibernia, used since 1730.

$$
\text { III.-The Duty Mark. }
$$

The Sovereign's Head, used to denote the payment of duty.

$$
\text { IV.-The Maker's Mark. }
$$

Some device, with or without the initials of the goldsmith; later the initials of his christian and surname.

$$
\text { V.-The Date Mark. }
$$

A Letter of the Alphabet, changing every year from A to Z, omitting $\mathrm{J}$, in cycles of twenty-five years. There is reason to believe that other characters than the Roman were adopted in the early cycles, but not having sufficient authority to alter them, we prefer leaving the list as it now stands: Thus in cycle 2, old English capitals were probably used. 
The Dublin Marks are these Twenty-five Letters of the Alphabet, always omitting the letter $\mathrm{J}$.

The time appointed for the letter to be changed, and the new punches put in commission, is the 29th or 30th of May in every year ; but this date has not been strictly adhered to, the changes having been made at various later periods in some years.

\begin{tabular}{|c|c|c|c|c|c|c|c|c|c|}
\hline \multicolumn{2}{|c|}{$\begin{array}{c}\text { CYCLE } 1 . \\
\text { RoMaN CAPITALS. }\end{array}$} & \multicolumn{2}{|c|}{$\begin{array}{c}\text { CYCLE } 2 . \\
\text { OLd ENGLISH CAPS. }\end{array}$} & \multicolumn{2}{|c|}{$\begin{array}{c}\text { CYCLE } 3 . \\
\text { Roman Capitals. }\end{array}$} & \multicolumn{2}{|c|}{$\begin{array}{c}\text { CYCLE } 4 . \\
\text { Roman SMaLL. }\end{array}$} & \multicolumn{2}{|c|}{$\begin{array}{c}\text { CYCLE } 5 . \\
\text { Roman CaPitals. }\end{array}$} \\
\hline & 1646-7 & & $1671-2$ & & 1696-7 & $a$ & $1721-2$ & & $1746-7$ \\
\hline & $1647-8$ & & $1672-3$ & & $1697-8$ & b & 1722-3 & & $1747-8$ \\
\hline & $1648-9$ & & $1673-4$ & & 1698-9 & C & $1723-4$ & & $1748-9$ \\
\hline & 1649-0 & & $1674-5$ & & 1699-0 & $d$ & $1724-5$ & & $1749-0$ \\
\hline & $1650-1$ & & $1675-6$ & & $1700-1$ & e & $1725-6$ & & $1750-1$ \\
\hline & 1651-2 & & $1676-7$ & & 1701-2 & $f$ & $1726-7$ & & 1751-2 \\
\hline & $1652-3$ & & $1677-8$ & & 1702-3 & $g$ & $1727-8$ & & $1752-3$ \\
\hline & $1653-4$ & & $1678-9$ & & $1703-4$ & $\mathrm{~h}$ & $1728-9$ & & $1753-4$ \\
\hline & $1654-5$ & & $1679-0$ & & $1704-5$ & 1 & $1729-0$ & & $1754-5$ \\
\hline & $1655-6$ & & 1680-1 & & $1705-6$ & k & 1730-1 & & $1755-6$ \\
\hline & $1656-7$ & & 1681-2 & & $1706-7$ & 1 & 1731-2 & & $1756-7$ \\
\hline & $1657-8$ & & 1682-3 & & $1707-8$ & $\mathrm{~m}$ & $1732-3$ & & $1757-8$ \\
\hline & $1658-9$ & & 1683-4 & & $1708-9$ & $\mathbf{n}$ & $1733-4$ & & $1758-9$ \\
\hline & $1659-0$ & & $1684-5$ & & $1709-0$ & 0 & $1734-5$ & & $1759-0$ \\
\hline & 1660-1 & & $1685-6$ & & $1710-1$ & $p$ & $1735-6$ & & $1760-1$ \\
\hline & 1661-2 & & 1686-7. & & $1711-2$ & $q$ & $1736-7$ & & $1761-2$ \\
\hline & 1662-3 & & 1687-8 & & 1712-3 & $\mathbf{r}$ & $1737-8$ & & $1762-3$ \\
\hline & $1663-4$ & & 1688-9 & & $1713-4$ & $\mathbf{S}$ & $1738-9$ & & $1763-4$ \\
\hline & 1664-5 & & $1689-0$ & & $1714-5$ & $t$ & $1739-0$ & & $1764-5$ \\
\hline & $1665-6$ & & 1690-1 & & $1715-6$ & $\mathbf{u}$ & $1740-1$ & & $1765-6$ \\
\hline & $1666-7$ & & $1691-2$ & & $1716-7$ & $\mathrm{~V}$ & $1741-2$ & $\mathrm{~V}$ & $1766-7$ \\
\hline & $1667-8$ & cos & 1692-3 & & $1717-8$ & W & 174a-3 & & $1767-8$ \\
\hline & 1668-9 & & $1693-4$ & $\mathrm{X}$ & $1718-9$ & $\mathrm{X}$ & $1743-4$ & $X$ & $1768-9$ \\
\hline $\mathbf{Y}$ & $1669-0$ & 进。 & $1694-5$ & $Y$ & $1719-0$ & $\mathrm{y}$ & $1744-5$ & $\mathrm{Y}$ & $1769-0$ \\
\hline Z & $1670-1$ & $\mathbb{2}$ & $1695-6$ & Z & $1720-1$ & $\mathrm{Z}$ & $1745-6$ & $Z$ & $1770-1$ \\
\hline \multicolumn{2}{|c|}{$\begin{array}{l}\text { Three Stamps. } \\
\text { 1. Harp crowned. } \\
\text { 2. Date Letter. } \\
\text { 3. Maker's Initials. }\end{array}$} & \multicolumn{2}{|c|}{$\begin{array}{l}\text { Three Stamps. } \\
\text { 1. Harp crowned. } \\
\text { 2. Date Letter. } \\
\text { 3. Maker's Initials. } \\
\text { These letters are not } \\
\text { fac-similes. }\end{array}$} & \multicolumn{2}{|c|}{$\begin{array}{l}\text { Three Stamps. } \\
\text { 1. Harp crowned. } \\
\text { 2. Date Letter. } \\
\text { 3. Maker's Initials. }\end{array}$} & \multicolumn{2}{|c|}{$\begin{array}{l}\text { FouR STAMips. } \\
\text { 1. Harp crowned. } \\
\text { 2. Date Letter } \\
\text { 3. Maker's Initials. } \\
\text { 4. Hibernia, in } 1730 .\end{array}$} & \multicolumn{2}{|c|}{$\begin{array}{l}\text { Four Stamps. } \\
\text { 1. Harp crowned. } \\
\text { 2. Date Letter. } \\
\text { 3. Maker's Initials. } \\
\text { 4. Hibernia. }\end{array}$} \\
\hline
\end{tabular}


DUBLIN ASSAY OFFICE LETTERS.

\begin{tabular}{|c|c|c|c|c|c|c|c|}
\hline \multicolumn{2}{|c|}{$\begin{array}{c}\text { CYCLE } 6 . \\
\text { Roman SMALL. }\end{array}$} & \multicolumn{2}{|c|}{$\begin{array}{c}\text { CYCLE } 7 . \\
\text { OLd ENGLiSH CAPS. }\end{array}$} & \multicolumn{2}{|c|}{$\begin{array}{l}\text { CYCLE } 8 . \\
\text { RoMan. }\end{array}$} & \multicolumn{2}{|c|}{$\begin{array}{c}\text { CYCLE } 9 . \\
\text { RoMan SMaLL. }\end{array}$} \\
\hline a & 1771-2 & & $1796-7$ & a & $1821-2$ & a & $1846-7$ \\
\hline b & $1772-3$ & & $1797-8$ & & 1822-3 & b & $1847-8$ \\
\hline C & $1773-4$ & & $1798-9$ & & 1823-4 & C & 1848.9 \\
\hline d & $1774-5$ & & $1799-0$ & & $1824-5$ & d & $1849-0$ \\
\hline e & $1775-6$ & & 1800-1 & & 1825-6 & $e$ & $1850-1$ \\
\hline$f$ & $1776-7$ & & $1801-2$ & & 1826-7 & $f$ & $1851-2$ \\
\hline$g$ & $1777-8$ & & 1802-3 & & $1827-8$ & $g$ & $1852-3$ \\
\hline $\mathrm{h}$ & $1778-9$ & & $1803-4$ & & $1828-9$ & h & $1853-4$ \\
\hline$i$ & $1779-0$ & & $1804-5$ & & $1829-0$ & i & $1854-5$ \\
\hline$k$ & $1780-1$ & & $1805-6$ & & $1830-1$ & $k$ & $1855-6$ \\
\hline & $1781-2$ & & $1806-7$ & & $1831-2$ & & $1856-7$ \\
\hline $\mathrm{m}$ & $1782-3$ & & 1807-8. & & 1832-3 & $\mathrm{m}$ & $1857-8$ \\
\hline $\mathrm{n}^{\prime}$ & $1783-4$ & & $1808-9$ & & $1833-4$ & $\mathrm{n}$ & 1858.9 \\
\hline 0 & $1784-5$ & & $1809-0$ & & $1834-5$ & 0 & $1859-0$ \\
\hline$p$ & $1785-6$ & & $1810-1$ & & $1835-6$ & $p$ & $1860-1$ \\
\hline$q$ & $1786-7$ & & $1811-2$ & & $1836-7$ & $q$ & 1861-2 \\
\hline$r$ & $1787-8$ & & 1812-3 & & $1837-8$ & $\mathbf{r}$ & $1862-3$ \\
\hline $\mathrm{S}$ & $1788-9$ & & $1813-4$ & & $1838-9$ & $\mathbf{S}$ & $1863-4$ \\
\hline$t$ & $1789-0$ & & $1814-5$ & & $1839-0$ & $t$ & $1864-5$ \\
\hline $\mathbf{u}$ & $1790-1$ & & $1815-6$ & & $1840-1$ & $\mathbf{u}$ & 1865 -6 \\
\hline V & 1791-2 & & $1816-7$ & & $1841-2$ & $\mathbf{V}$ & $1866-7$ \\
\hline W & $1792-3$ & 201 & $1817-8$ & & 1842-3 & W & $1867-8$ \\
\hline $\mathrm{X}$ & $1793-4$ & & $1818-9$ & 1 & $1843-4$ & $\mathrm{X}$ & $1868-9$ \\
\hline $\mathrm{y}$ & $1794-5$ & 跑 & $1819-0$ & $\mathbf{Y}$ & $1844-5$ & $y$ & $1869-0$ \\
\hline $\mathbf{Z}$ & $1795-6$ & $\mathscr{W}$ & $1820-1$ & Z & $1845-6$ & $\mathrm{Z}$ & 1870.1 \\
\hline \multicolumn{2}{|c|}{$\begin{array}{l}\text { Four StamPs. } \\
\text { 1. Harp crowned, Uni- } \\
\text { corn, or Plume. } \\
\text { 2. Date Letter. } \\
\text { 3. Maker's Initials. } \\
\text { 4. Hibernia. } \\
\text { The three Standards di- } \\
\text { rected to be uned after } \\
\text { 1784 are the Harp, Uni- } \\
\text { corn, or Plume. }\end{array}$} & \multicolumn{2}{|c|}{$\begin{array}{l}\text { FIVE StaMPs. } \\
\text { 1. Harp crowned, Uni- } \\
\text { corn, or Plume.' } \\
\text { 2. Maker's Mark. } \\
\text { 3. Date Letter. } \\
\text { 4. Hibernia. } \\
\text { 5. The King's Head in } \\
\text { 1807. }\end{array}$} & \multicolumn{2}{|c|}{$\begin{array}{l}\text { Five Stamps. } \\
\text { 1. Harp crowned, Uni- } \\
\text { corn, or Plume. } \\
\text { 2. Maker's Mark. } \\
\text { 3. Date Letter. } \\
\text { 4. Hibernia. } \\
\text { 5. King's Head. } \\
\text { In September, } 1825 \text {, the } \\
\text { letters changed from small } \\
\text { to large. }\end{array}$} & \multicolumn{2}{|c|}{$\begin{array}{l}\text { FIVE Stamps. } \\
\text { 1. Harp crowned, Uni- } \\
\text { corn, or Plume. } \\
\text { 2. Maker's Mark. } \\
\text { 3. Date Letter. } \\
\text { 4. Hibernia. } \\
\text { 5. King's Head, or } \\
\text { Queen's. }\end{array}$} \\
\hline
\end{tabular}




\section{EXAMPLES OF ENGLISH AND FOREIGN HALL MARKS.}

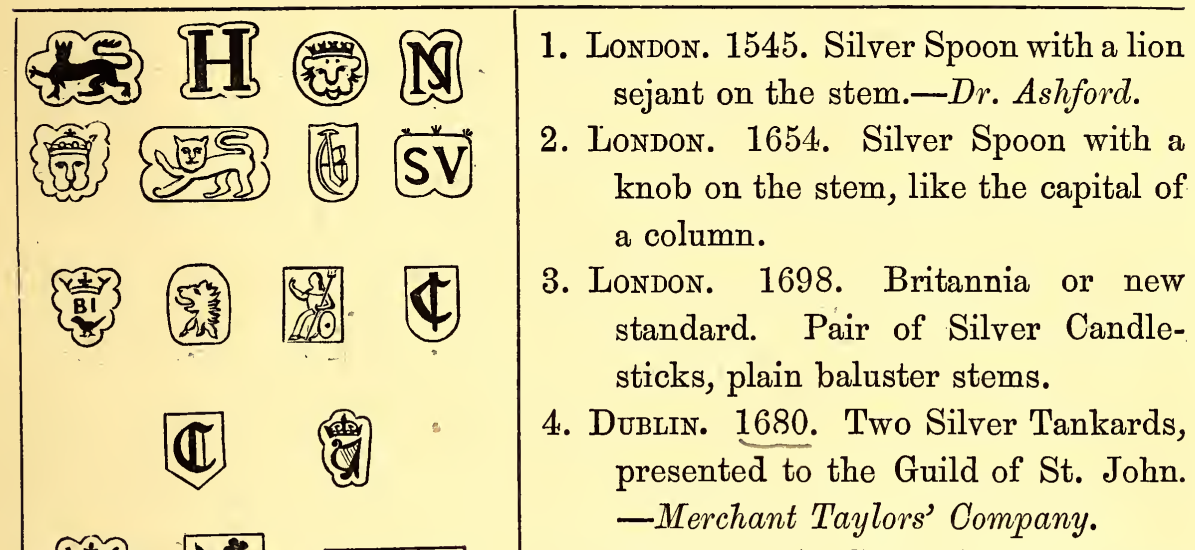

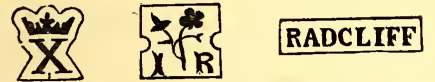
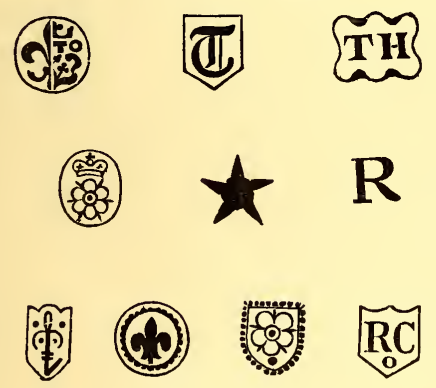

5. Exeter? 1637. Silver Apostle Spoon. -The Rev. T. Staniforth.

6. Enaland. Circa 1630. Silver Apostle Spoon, stamp of half rose and half fleur de lis.-The Rev. T. Staniforth.

7. England, Norwich? Circa 1576. Cocoanut Cup, carved, silver mounting of the 16 th century.-S. K. Museum.

8. England. Circa 1680. A Silver Spoon with flat stem and heart-shaped end, as on others of the end of the 17th century.-Rev. T. Staniforth.

9. Paris. Circa 1720. Pair of Silver Boxes. (Loan Catalogue, 6413).Lord Bateman.

10. France. Circa 1784. Pair of Silver Powder Boxes, with the arms of the Duc de Rohan.-Felix Slade, Esq.

11. France. Circa 1750. Gold enamelled Snuff Box, temp. Louis XV.-C. Goding, Esq.

12. France. Circa 1740. Silver Sugar Pot and Cover, rococo scrolls, \&c.South Kensington Museum, No. 4246. 


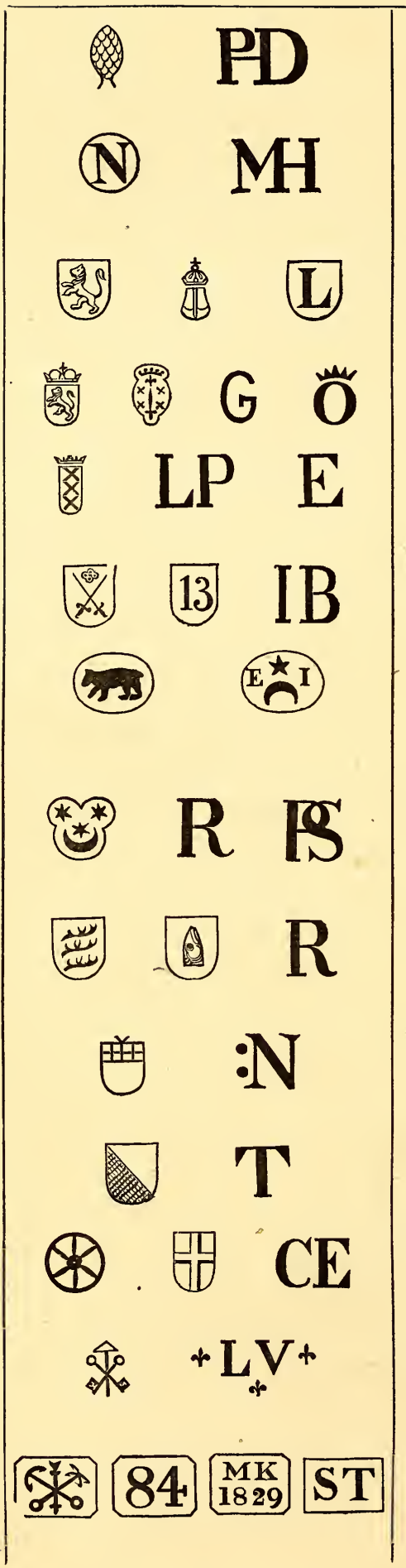

13. Augsburg. Circa 1650. Silver Ewer and Salver. (Loan Catalogue, 6251). -Duke of Manchester.

14. Noremberg. Circa 1650. Silver Standing Cup. (Loan Catalogue, 6197.)Her Majesty the Queen.

15. Holland. Circa 1642. Silver Salver with inscription. (Loan Catalogue, 6182).-Baron Lionel de Rothschild.

16. Haarlem. Circa 1700. Oviform Silver Tea Canister.-S. K. Museum.

17. Amsterdam. 17th century. Oval Silver Box and Cover, with large repoussé flowers.

18. Saxony. 17th century. Silver gilt Cup, repoussé historical subjects.

19. Berne. 1690. Large Lion Cup, given by Will. III. to the city of Berne. (Loan Cat. 6363).-Baron M. de Rothschild.

20. Doccum. 1648. Silver Beaker, engraved with costume figures, \&c.South Kensington Museum, No. 3636.

21. Wurtemberg. Circa 1660. Silver Beaker, with landscapes and figures. (Loan Cat. 6394.) - J.D. Gardner,Esq.

22. VIEnNa. 16th century. Silver Salt Cellar. (Bernal Coll.)—South Kensington Museum.

23. UтREChт. 17th century. Silver Beaker with bells and Dutch inscription.

24. Mayence. Circa 1620. Silver Tankard, repoussé classical subject. (Loan Cat. 6324).-E. Waterton, Esq.

25. Rome. 1790. Silver Ewer of the late Card. York, made by L. Valadini.Duke of Hamilton.

26. St. Petergsburg. 1829. Silver Cup, 84 parts fine, 16 alloy.-W. Chaffers, Esq. 


\section{FOREIGN HALL MARKS.}

The following imperfect list is here given merely as an attempt to reduce to a system, the marks adopted by other countries in marking their plate. No works have hitherto been published on the subject, and therefore great allowance must be made for any inaccuracy in the appropriation of localities. It is in fact a few notes made by the author alone, on the inspection of pieces of plate which have come under his immediate observation, he will therefore feel obliged for further information from those gentlemen who have opportunities of assisting him.

The great centres of Goldsmiths' work, Augsburg and Nuremberg, where nearly all the finest pieces of plate were produced in the 16th and 17th centuries, do not appear to have dated their works, as we seldom find more than two marks, viz: that of the city and that of the maker. Very few cities did so. Paris seems to have used a date letter, and it is to be hoped somebody may be induced to investigate the subject, and do as much for Paris as has been done for London.

Amsterdam and other Towns in Holland probably had date marks, as a letter is generally found in juxta-position with the town mark and that of the maker. On many pieces of German plate are stamped the figures 13 or 12 ; these numbers refer to the quality of the silver according to Cologne weight, viz. 13 parts of fine silver and 3 parts alloy, making up the 16 loths of which the Cologne pound consisted. It is still adopted in the Northern parts of Germany, but troy weight of 12 ounces in the pound is mostly used.

In Russia the plate is usually stamped with 84, being the number of parts of pure silver in the hundred.

\section{GERMANY.}

Augsburg ............ A pine apple, the arms of the city.

Nuremberg .......... The capital Roman letter $\mathrm{N}$.

Prussia ................ Spread eagle (one neck).

Austria................ Imperial eagle (two necks).

Cologne............... Three crowns in chief on a shield.

Mayence .............. A wheel with six spokes.

Vienna ............... A shield of arms with two bars. 
WURTEMBERG. Three stag's horns on a shield.

SAXONY Two crossed swords ; sometimes "13."

Cleves Three lines forked ends, crossed.

RAtisbon Two crossed keys.

WorMs A single key.

Bremen A single key.

Hungary A double cross crowned.

HALL A crescent and star above.

Biberach A wolf rampant.

Greuzenbach A fish on a shield.

KoningsBerg . A crowned head.

Westphalia A horse galloping.

Coblentz A fleur de lis.

KeyserberG A saddle.

BieL Two hatchets crossed.

Ravensbura A castle with two towers.

Speyer \& Prague. A castle with three towers.

Hamburg A castle with three towers.

ANTWERP A citadel, from which issue two hands.

UNKNOWN A griffin sejant.

UNKNOWN $F R$ in monogram; a small $N$ and an $S$ on each side.

UnKNown .............. $N A$ crowned and 92 beneath.

UNKNOWN ............ $T F$ under an imperial crown, an eagle in the centre.

UNKNOWN ............... An anchor.

UNKNOWN ............. $Z$ on a shield.

UNKNOWN ............. A double diamond with a $C$ in each space.

UNKNown ............. A spread eagle on a rock.

UNKNOWN ............. A horse galloping and a triangle.

UNKNOWN ............. An open hand crowned.

UNKNOWN ............. A shield with three squares, two and one.

UNKNOWN .............. A sword and an arrow crossed.

UnKNOWN .............. Two banners crossed.

\section{HOLLAND AND BELGIUM.}

Holland

A lion rampant, usually accompanied by the mark of a town and Goldsmith's mark.

HAARLEM A dagger, with 4 stars at the sides and a 
cross at the point, sometimes crowned, and occasionally the lion rampant is added.

UTRECHT

A shield of arms of the town and lion rampant.

HAGUE

A lion rampant for Holland, a stork holding a horse-shoe in its beak, a letter crowned, and a monogram.

Amsterdam .......... Three saltire crosses, one above the other on a shield, crowned; recent stamps have a letter at the side.

Maestricht? ........ A star of six points.

Docсuм ................ A crescent and three stars.

Flushing .............. A silver flagon or amphora crowned.

ORANGE (House of) ... A hunting horn on a shield.

Leyden ................. Two crossed keys.

HaInHaUlt .......... Four lions on a shield, two and two.

BREDA .............. Three saltire crosses, two above, another BERGEN OP ZOOM... $\}$ below, on a shield.

Brussels .............. St. Michael killing the dragon.

$\left.\begin{array}{l}\text { DordReCHT } \\ \text { DeLrt........................... }\end{array}\right\}$ A shield, party per pale.

Unknown .............. The letter $\mathrm{V}$ on a shield crowned.

UnkNown ............. A hunting horn on a shield.

UnKNOWN ............. A rose under crown, and lion rampant.

UNKNOWN ............. A cock, a shield of arms and a small letter, and the lion rampant of Holland.

UnKNown ............. Two lions, one above the other, and a crown, and the lion rampant.

\section{VARIOUS.}

St. Petersbura......... One sceptre crossed by two anchors.

Moscow ............... St. George and the dragon.

SwEDEN ................ Three crowns, two over one.

BeRNe $\quad$................ A bear passant.

Rome .................. Two crossed keys.

Spain, Fuente d'onoro. The pillars of Hercules crowned "Fuente" and a pelican "in her piety."

Burgundy (House of) A steel (fer à feu) crossed by two clubs. SchaffHAUSEN ......... The fore-part of a goat. 


\section{FRANCE.}

In France a similar system of stamping gold and silver wares was adopted, as early as the thirteenth century, but the means of ascertaining the date of manufacture is not so easily determined as in England.

In the Livre des Metiers, for the regulation of trades in France, made bo Etienne Boileau, Provost of Paris in the year 1260, we find the rules by which the goldsmiths were regulated, and masters were appointed to see them carried into effect. This was probably the first institution of the Goldsmiths' Company in Paris, in which we meet with the following clauses, in the old language of the time of Saint Louis :-

"Nus orfevres ne puet ouvrer d'or à Paris qu'il ne soit à la touche de Paris ou mieudres, laquele touche passe tous les ors de quoi on œuvre en nule terre." Again, “ Nus orfevres ne puet ouvrer à Paris d'argent que il ne soit ausi bons come estelins ou mieudres."

No goldsmith may work gold in Paris which is not of the Paris touch or better, which touch or standard surpasses all the gold which is worked in any other country.

No goldsmith may work at Paris any silver which is not as good as sterling (of England) or better.

"Nus orfevres ne puet avoir que un aprenti estrange, mes de son lignage ou de lignage sa fame, soit de loing soit de près, en peut.il avoir tant come il li plaist." No goldsmith can have but one apprentice who is a stranger, but as many of his or his wife's relations as he pleases.

“ Nus orfevres ne puet ouvrer de nuit, se ce n'est à l'euvre lou Roy, la Roine, leurs anfans, leurs freres et l'evesque de Paris." No goldsmith may work at night except on work commanded by the King, the Queen, their children, their brothers, and the Bishop of Paris. 
"Nus orfevres ne doit paiage ne coustume nule de chose qu'il achate ne vende apartenant a leur mestier." No goldsmith shall pay any tax or duty on anything he buys or sells appertaining to his trade.

"Nus orfevres ne puet ouvrir sa forge au jour d'apostele, se ele n'eschist au Samedi, fors que un ouvroir que chascun ouvre à son tour à ces festes et au diemanche; et quanques cil gaaigne qui l'ouvroir a ouvert, il le met en la boiste de la confrairie des orfevres, en laquele boiste en met les deniers Dieu que li orfevre font des choses que il vendent ou achetent apartenans à leur mestier, et de tout l'argent de celle boiste done-on chascun an le jor de Pasques un diner as povres de l'Ostel Dieu de Paris." No goldsmith may work his forge on the day of the fête of the Apostles, if it does not fall on a Saturday, with the exception of the shop, where every one works in his turn on the fête days and on Sundays, and all that he gains who has an open shop on these days he shall put in the box of the Confrerie of Goldsmiths, in which box the alms are placed, the contents being devoted on Easter day every year for a dinner to the poor at the Hotel Dieu of Paris.

In an ordinance of Philippe le Hardi, A.D. 1275, the argentarii were compelled to stamp their works with the seign of the town in which their forge was situated, on pain of confiscation of the goods; and in the reign of Philippe le Bel, A.D. 1313, gold was ordered to be stamped with the punch of the Goldsmiths' Company of Paris, which was kept by the prudhommes of the Company.

"Tout orfevre qui négligerait de faire marquer ses ouvrages serait puni de corps et d'avoir," that is by fine and imprisonment.

It was also ordained that each city should have a particular mark for works in silver.

This was the origin of the Hall-mark in France, each town having a different device and a letter, changing every year at the election of the new masters.

The marks for goldsmiths' work made at Paris was anciently of two sorts, the maker's mark, and the assay mark of the maison commune, or common hall. The first was the signature of the goldsmith, who usually adopted some emblem, as a star, cross, rose, \&c., surmounted by a fleur de lis.

We are further informed by Pierre le Roy, Statuts et Privileges du Corps des Marchands Orfévres de Paris, collected from ancient 
documents relative to the government of the goldsmiths' trade, that a common stamp was ordered to be kept at the common hall of the goldsmiths' community called the Contremarque, or the punch of Paris (poinçon de Paris), the safe keeping of which was entrusted to the wardens in charge; and all plate of gold or silver made in Paris was to be taken to them, and assayed and marked with it.

The number of goldsmiths of Paris was limited to 300 .

Those who had regularly served their apprenticeship and aspired to become masters, were strictly examined by the wardens of the company as to the weights and proportions of the mark, the price of gold and silver, the manner of alloying the precious metals, and all matters relating thereto. The wardens were also required diligently to inquire as to the morals and general conduct of the aspirant, who was moreover to execute a chef d'ceuvre, and submit it for their approval. He was then presented to the Mint, and again examined. If considered duly qualified, he entered into a bond for a thousand livres (tournois), and received a punch, with which he was to stamp all his works. This punch was ordered to be a fleur de lis, crowned with a device, or initial letters of his name. An impression of this was made upon two tablets of brass, one for the Mint, and the other for the maison commune.

When a goldsmith had completed a piece of plate, he first placed his own stamp upon it, and then took it to the maison commune to be assayed, and countermarked with the common stamp of the Company. The assay was ordered to take place in the Company's offices-that is to say, those of gold by aqua fortis (eau forte), those of silver (à la coupelle) by the cupel, or crucible, and not otherwise.

The titre or standard was, for gold 22 carats fine, and silver 11 deniers 12 grains; small gold wares, such as crosses, buckles, buttons, snuff-boxes, and jewels, were to be of 20 carats fine. The denier, in computing the standard of silver, was an imaginary weight, like the carat in gold, the pound was divided into twelve parts, and the carat subdivided into 24 grains.

By an ordinance of Louis XII., given at Blois in 1506, after confirming ancient privileges, it enjoins goldsmiths to have their works countermarked by the sworn masters or wardens of the 
maison commune, who had the contre-poinçon in their keeping. It goes on to say that this contre-poinçon was to be changed every year, registered at the Mint, and stamped upon a table of brass, with the name of the wardens. It also definitively assigns one particular spot for goldsmiths to reside, namely, opposite the money changers, mercers, jewellers, and others who had any trade in the precious metals. This spot was for several centuries the Pont au Change, or Grand Pont.

In 1493 the maker's mark, in addition to the fleur de lis, had two dots or pellets, a sort of emblem to remind the goldsmith that the law only allowed him 2 grains of remedy, that is, an allowance of 2 grains more in the alloy than exactly specified by the law, and if that was exceeded the plate was broken up. In 1506 the goldsmiths added to the mark of the fleur de lis and two pellets, the initial letters of their christian and surnames. The size of the stamp, left at first to the discretion of the goldsmith, was fixed by Louis XIV. in 1679, to two lines high, by one and a quarter broad. This mark existed up to 1789 .

The second, or assay mark, was impressed by the Corporation, and proved that the article had been assayed, and found to be as good as the Paris standard. This stamp can be traced back as far as 1275, as before noticed. The puncheon was at Paris a letter of the alphabet crowned, changing every year with the new masters, or gardes du metier, in alphabetical order. We are informed by Pierre de Rosnel, in the third part of his Mercure Indien, that the letter for the year 1472 was $\mathrm{M}$; but as several irregularities occur from incidental circumstances, the exact order cannot be ascertained without consulting the minutes of the Mint, where all the marks were registered on a plate of brass by the identical punches. The variable mark continued in use until 1783, $\mathrm{U}$ being the letter for that year, when Louis XVI. assigned to each community of goldsmiths in France an invariable mark, that of Paris being the letter P crowned. From 1789 we find no stamp until 1797: After two ineffectual attempts under Henry III. and Louis XIII., the duty.known by the name of "droit de controle" was definitely settled by Louis XIV. in 1672. The Mint letter of the town surmounted by a fleur de lis, then attested the payment of the duty.

In 1681, the Fermiers du Controle obtained permission of the 
King that every work commenced should be impressed with a stamp called the charge, showing that the goldsmith was indebted or answerable to them for the payment of this duty. After the piece was finished and the duty paid, a stamp was impressed called the discharge, attesting the payment.

Goldsmith's work, therefore, after 1681, ought to have four stamps-

1. The stamp of the goldsmith.

2. The stamp of the maison commune.

3. The stamp of the charge or duty payable.

4. The stamp of the discharge or duty paid.

For Paris the stamp of the charge of the Fermiers has nearly always been an $\mathrm{A}$, the mint letter of this city, accompanied by some change of fashion, when the farming of the duty changed hands. The stamp of the discharge represented generally the head of a man, or some animal, changing like the other.

There were various sized stamps for large or small works.

In the Wardrobe Accounts of Edw. I. we have a very early record of this Hall-mark in the year 1300. (Lib. Gard. Soc. Ant. 352). "Item, viij. cocleares argenti signata in collo signo Parisius scilicet, de quandam flore glegelli"--which may be thus rendered-Item, eight silver spoons, marked on the neck or stem with the Paris mark, that is, say a certain fleur de lis.

In the Inventory of the Dukes of Burgundy, 1423, " Pour un pou avoir amende $\mathrm{x}$ marcs $\mathrm{jj}$. ounces $\mathrm{xv}$. esterlins dudit or, estant à xix. karas, pour faire aultre vaisselle et l'avour fait venir à xix. karas et un quint, qui est or de touche et au dessoubz n'oseroit on ouvrer."

Again, in the will of Thomas Rotherham, Archbishop of York, A.D. 1498, are the following allusions to the touches or Hall marks of Paris, London, and Bruges :- " Item volo quod Thomas Sentegeorg habeat sex taceas sive Bollezbasse Stantes (standing low bowls), in fundo tacearum sunt flores tres sunt Paris towch, et ponderant de Troy LXXI unc'; aliæ tres sunt London towch, et ponderant cum coopertor, C unc' de Troy.

"Volo etiam quod habeat duas ollas argent' wynding chaced, quarum una et Brugg's towch, altera London est ponderant et Troy XI. unc." (Lib. Nig. Scacc. Vol. II. p. 676.)

La Croix (Histoire de l'orfevrerie) says :- "The Revolution of 1789 disorganized all the Trade Guilds and Communities, and 
the Goldsmiths did not escape the universal shipwreck which ingulphed at the same time Religion, Royalty, and the Public fortune. Of what avail could be the Goldsmiths trade in a time when sceptres and crowns were broken, all the church plate melted and jewels placed on the altar of the country, when gold and silver coin was replaced by bell-metal and assignats. The Goldsmiths' trade could not survive the Monarchy and the Ecclesiastical power which had given it birth, and under which it had flourished for fifteen centuries."

From 1789, therefore, little or no attention was paid to the stamping of plate in France until the passing of the Act of 1797, so that for a period of nearly eight years, Goldsmiths were allowed to make whatever quality of gold and silver articles they pleased.

The following extracts are from the Act of the 19th Brumaire, An VI. (19 Nov., 1797), indicating the stamps used on gold and silver plate in France at that period.

Preamble.-The Council of Five Hundred, after having heard the Report of the Commission of Finance, considering that the reestablishment of the supervision of the guarantee of Standard of works in gold and silver is necessary to the prosperity of this branch of National commerce as well for the interior as abroad; at the same time that the dues to be collected on these objects are indispensable to the Public Treasury, to contribute, with the other revenues of the Republic, for the maintenance of various parts of the service, declare the urgency and take the following resolution :-

Section I. -Of the Standards of Gold and Silver Works.

Art. 1.-All works of gold and silver made in France must be conformable to the standards prescribed by the law, respectively, according to their quality.

Art. 2.-The standards or quantity of pure gold or silver contained in each piece, are expressed in thousandths (millièmes). The old denominations of karats and of deniers to express the degree of purity of the precious metals being discontinued.

Art. 3.-It is however permitted during one year from this date to employ in the acts or writings which come under the observation of any public officer, the ancient terms of karats and deniers or their subdivisions, but only immediately following the number of milliemes which express the true quality of precious metal. 
Art. 4.-There are three legal standards for works in gold and two for silver.

For gold 1st of 0.920 or $22 \frac{2 \sqrt{3}}{32}$ karats. 2 nd of 0.840 or $20 \frac{5 \frac{1}{2}}{32}$ karats. 3 rd of 0.750 or 18 karats.

For silver 1st of 0.950 or 11 deniers $9 \frac{7}{10}$ grains. 2nd of 0.800 or 9 deniers $11 \frac{1}{2}$ grains.

Art. 5.-The remedy (tolérance) for gold is 3 millièmes, and for silver 5 millièmes.

Art. 6.-The makers may employ at their option any one of the standards mentioned in Art. 4 for works in gold or silver, whatever the size or description of pieces fabricated.

\section{Section II.-Of Punches.}

Art. 7.-The guarantee of the standard of works of gold and silver is assured by punches, they are applied on every piece, after the assay, conformably to the following rules.

Art. 8.-There are three principal punches to mark gold and silver works. 1st. That of the maker; 2nd. That of the standard; and 3rd, that of the Assay Office (Bureau de garantie).

There are also two little punches, one for small works of gold, the other for small works of silver, too small to receive the impress of the three preceding marks.

There is also a particular punch for old pieces of plate called de hasard.

A second for works coming from abroad.

A third for works covered with gold and silver (doublé ou plaqué).

A fourth called the stamp of verification (recense), which is applied by public authority, when any doubt arises as to the genuineness of the standard or of the stamps.

Lastly a particular punch to stamp ingots of refined gold or silver.

Art. 9.-The punch of the maker bears the initial letter of his name with some symbol, which he can select and have made for himself, observing the correct forms and proportions, as established by the administration.

Art. 10.-The standard punches have a stamp of $a$ cock, accompanied by one of the Arabic numerals 1, 2, 3, indicating the 1st, 2nd, or 3rd standard fixed in the preceding section. These punches are uniform throughout the Republic, but each punch has a particular form, easily distinguished by the eye.

Art. 11. -The punch of every assay office has a characteristic sign which is determined by the administration. This sign is 
changed as often as may be considered necessary to prevent the effect of a theft or unfaithfulness.

Art. 12.-The little punch destined for the small works in gold has the stamp of a cock's head. That for small pieces of silver, a fasces or bundle of rods.

Art. 13.-The punch for old work (poinçon de vienx) solely to mark works styled de hasard, represents an axe. That to mark works coming from abroad contains the letters E. T.

Art. 14.-The punch of each maker de doublé ou de plaqué has a particular form determined by the administration. The maker also indicates on his works, the numeral denoting the quality of the precious metals employed.

Art. 15.-The punch of verification (recense) is also determined by the administration, altered according to circumstances.

Art. 16.-The punch to stamp refined gold and silver ingots is also determined by the administration, and is uniform throughout France.

Independent of the usual Hall Marks on plate, stamped at the time of its manufacture, there is frequently seen a diminutive stamp which has no reference to its origin either of country or date, or whether it be new or old. This mark is called the poinçon de recense, and is placed upon all gold or silver articles either new or second hand, bought or sold in France.

According to an Ordinance of Louis Philippe, dated 7 April, 1838 , this stamp of verification was placed upon all plate, whether bearing the French hall mark or not, and every other description of gold or silver works which were at that time in commerce, and it enacted that all gold and silver works should, within three months of the date thereof, be taken to the assay office and stamped according to its standard, as a guarantee of its quality; we give a translation of this important act, and a plate of the stamps directed to be used as therein stated.

7-12 April, 1838, Louis Philippe, \&c.-Royal Ordinance directing a general verification of the quality of gold and silver works, and the employment of new punches.

Referring to the clauses 7, 8, and 15 of the act of the 19 Brumaire An VI, (9th Nov., 1797) and taking into consideration that numerous seizures have taken place of gold and silver works, in which the State punches have in a great degree been counterfeited, and that it is highly important as well, that the public 
guarantee should be preserved, as to secure the revenues of the Treasury, to put a stop to the use of false punches; It is enacted :-

Art. 1.-From and after the 10th May following, a punch of verification shall be applied on all the works of gold and silver now existing in commerce, and bearing the impress of the legal marks.

Art. 2.-From the same date the new punches of standard and guarantee or assay and the punch of the countermark (of which a table will be published with this minute,) shall be exclusively employed in all the assay offices.

Art. 3.-The special punches for watch cases, and other watchmakers work, decreed by article 2 of the Act of the 19th Sept., 1821, shall be repealed.

French watches shall be marked with the ordinary punches of standard and assay. Those coming from abroad shall be marked with a special punch for imported watches, which shall be applied in the offices designated by the Act of the 2nd July, 1836.

Art. 4.-The punch of the standard and that of the assay office shall consist of a single stamp, which shall bear a particular sign for each office. A punch called the Countermark shall be placed every decimètre (4 inches) on chains, and other works in gold of the same class.

Art. 5.-At the expiration of three months from the day when the new punches are to be used, all merchants, working goldsmiths, jewellers, watchmakers, cutlers, armourers, cabinet makers, and all other workmen and merchants dealing in gold and silver works, shall be compelled to carry to the Assay Office of their districts, the gold and silver works in their possession, to be there marked, free of expense, with the punches of verification and countermark.

Art. 6.-At the expiration of the term fixed for the verification, the gold and silver works marked with the ancient punches which shall be found in commerce, without being stamped with the punch of verification, shall be reputed as unmarked, and the holders subject to the condemnations decreed by the law.

An appendix to this Act gives a table of the punches of Standard and Assay, and of Verification, of works in gold and silver as prescribed by the ordinance; the designations, forms and types of these stamps are engraved in the annexed plate, as they appear on gold and silver, but considerably enlarged. 


\section{TABLE OF FRENCH STAMPS}

Of Standard and Assay, and of Verification of Gold and Silver works, for Paris and the Departments, as directed by the Act of 7th April 1838.

|F.T Stamp for Foreign wares.

Head of a Greek Physician. Gold. Standard No. 1. 0.920.

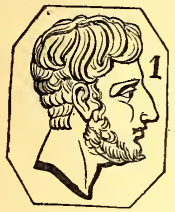

Paris and Departments.

Head of a Greek Physician. Gold. Standard No. 2. 0.840 .

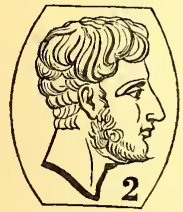

Paris and Departments.

Head of a Greek Physician. Gold. Standard No. 3. $0.75 \circ$.

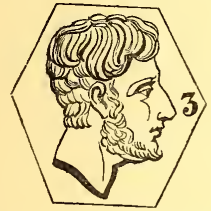

Paris and Departments,

Head of Minerva.

Silver. Standard No. 1. 0.950.

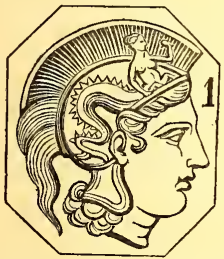

Paris and Departments.

- Head of Minerva

Silver. Standard No. 2. $\quad 0.800$.

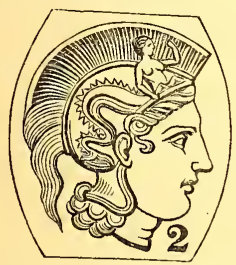

Paris and Departments.
Head of an Eagle. Gold Assay mark.

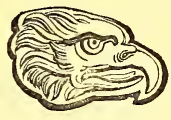

PARIs.

Head of a Rhinoceros. Countermark for Gold Chains.

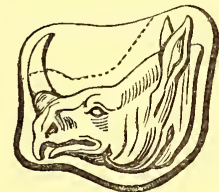

Paris and Departments

Head of a Horse. Gold Assay mark.

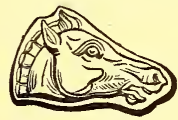

DepartMENTS,

Head of a Wild Boar. Silver Assay mark.

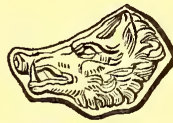

PARIS.

A Crab.

Silver Assay mark.

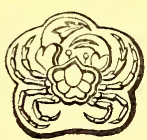

DepartMENTS.

A Wervil (Large).

Guarantee of Staridard.

Foreign Gold and Silver.

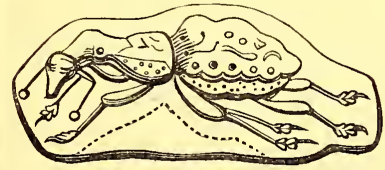

Paris and Departments,
A WeEvil (Small).

Guarantee of Standard.

Foreign Gold and Silver.

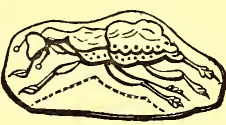

Paris and Departments.

A Chimera (Large).

Silver. Watches imported.

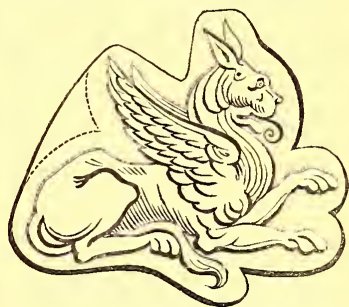

Paris and Departments.

A Chimera (Small).

Gold. Watches imported.

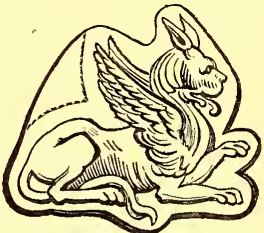

Paris and Departments.

Head of a Giraffe. Gold and Silver.

Stamp of Verification.

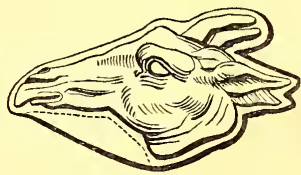

Paris and Departments.

Head of a Bull Dog. Gold and Silver.

Stamp of Verification.

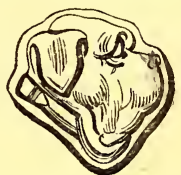

Paris and Departments,

Notw.-The dotted lines indicate the forms of the Punches for the Paris Assay Office. 



\section{AN ALPHABETICAL TABLE}

OF THE

\section{COMMUNITIES OF GOLDSMITHS IN THE SEVERAL TOWNS OF FRANCE, EXISTING PREVIOUS TO 1786,1786 \\ WITH THE DATES OF THEIR FOUNDATION, AND THE EMBLEMS ADOPTED BY THEM FOR STAMPING GOLDSMITH'S WORK.}

(From 'Histoire de l'Orfévrerie,' par Paul Lacroix et Ferdinand Seré. Paris, 1850).

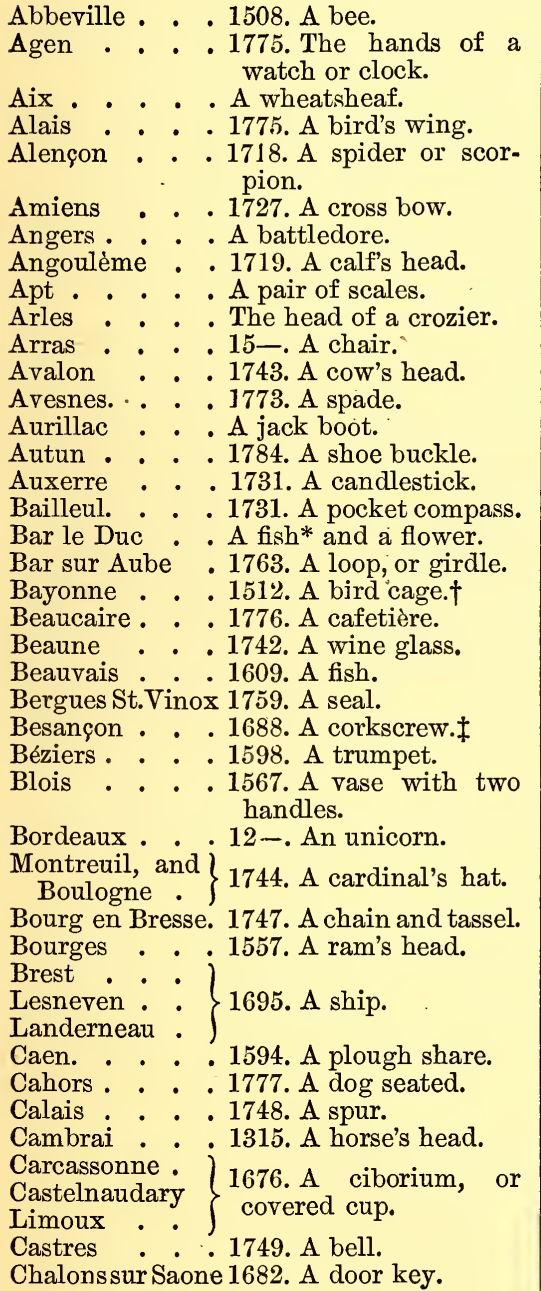

Chalons surMarne 1749. A watch key.

Chartres . . 15-. A dove flying upward.

Chateau Gonthier 1757. Compasses.

Chateau Thierry. A cock.

Chattellerault . 1758. A penknife, or a burnisher.

Chatillon . . 15-. A castle.

Chaumout . 1744. A half moon.

Clermont . . 15-. A tree.

Cognac . . 1762. A bolt, or spear head.

Colmar. . . A glove.

Compiègne . 1667. A stag's head.

Coutances. . . 1751. An inkstand.

$\left.\begin{array}{c}\text { Daligre, for- } \\ \text { merly Marans }\end{array}\right\}$ 1758. A porringer.

Dieppe . . 1599. A flat fish.

Dijon . . . 15- A globe on stand.

Dinan . . . 1746. An anchor.

Dole. . . A funnel.\$

Douai . . Arms, two cross branches andasquare surmounted by a crown

Draguignan . . 1751. An ear of barley or wheat.

Dunkerque . . 1753. A rugged branch or sea weed.

Etampes . . A lobster.

Falaise . . 1750. A lancet.

Fécamp . . 1745. A stirrup.

Fontenay . . 1574. A flambeau.

Gien . . 1757. An arrow.

Gisors . . . 1754. A branch of yew.

Grasse . . . A four-pronged fork.

Grenoble . . A dolphin.

Guise and Vervins 1745. The head of a staff. Havre . . . 15-. A lance and flag.

Joinville . . 1759. A weatber cock.

Issoire . . . 1766. An acorn.

Issodoun . . 175̌. A cup.

La Charité . 1757. A holy water sprinkler.

Lafère . . . A pink.

Landrecy : : 1779. A pointed instrument, or an eraser.

Langheac . . 1784. A carpenter's rule.

* The barbel.

+ Another mark is also used, displaying the arms of the city.

$\ddagger$ In addition to this another mark was used, consisting of two C's back to back, surmounted by a fleur de lis.

\& A counter mark was also used by this community, two C's back to back, surmounted by a ducal coronet. 
Langres . . 1566. A clasp knife.

Laon . . . An artichoke.

La Rochelle . 1698. A griffin.

Laval . . . A frog.

Le Vigan . . . 1775. A gridiron.

N. D. de Liesse . 1749. A hatchet.

Lille . . . A bird flying to the right.

Limoges . . 1719. A porter's basket.

Lisieux . . 1750. A cornucopia.

Longwy . . A label of 3 points.

Lons le Saulnier. 1780. A lamp lighted.

Lorient . . 1745. A fortification, or a blazing star.

Loudun . . 1646. A lantern

Lunel . . . 1775. A fir cone.

Luçon . . . 1758. A shuttle.

Lyon . . . A lion's head.

Macon . . 1600. An open hand.

Manosque. . A closed book.

Le Mans . . 1757. A flower (tulip).

Mantes . . . A lozenge engrailed.

Marennes . . 1777. An oyster.

Marseille . . 12-. A bow of ribbon.

Maubeuge. . An eye.

Meàux . . . A cat lying down.

Melle . . An ear

Melun . . . 1727. An eel.

Mende . . . 1767. A butterfly.

Mézierès . . 1746. A cannon.

Metz . . . 1635. A peacock.

Milhau . . 1770. A flower (meadow saffron).

Montargis. . 1737. A comb.

Montauban . . 1705. A steelyard.

Montpellier . A syphon or chemical retort.

Morlaix . . 1607. A square pillar.

Moulins . . 1736. The sails of a windmill.

Nantes . . . 1759. A spear.

Narbonne. . 1669. A tobacco pipe.

Nevers . . . 1757. A bottle.

Nimes . . . 1586. A porcupine.

Niort . . . 15-. A pipkin.

Noyon . . . 1748. A shallow pan.

Orleans . . 1611. Bust of Joan of Arc.

Paris . . 1260. The letter P. crowned.

Parthenay . . 1745. A flat fish (skate).

Pau . . A cow.

Payrat : $:\left\{\begin{array}{l}\text { A cow. } \\ \text { 1753. A pair with three }\end{array}\right.$

St. Colombe . $\}$ leaves.

Perigueux . A snail.

Perpignan . A rat.

Pézénas . . 1586. A rake.

Poitiers . . A Turk's turban.

Pons en Saintonge 1785. A bee hive.

Pontoise . . 1752. A pink.*
Provins . . 1759. The provence rose,

Puy en Velay. . 1367. A pulley.

Quimper . . 1780. A hand-saw.

Reims . . . 1560. A bunch of grapes.

Rennes . . . 1579. An ape seated.

Réthel . . . 1660. A quiver of arrows.

Riez . . A pot with handle.

Riom . . . A cross moline.

Rochefort . . 1713. A rock.

Rodez . . . 1777. A vase. $\dagger$

Rouen . . . : 13-. A cluster of apples on a branch.

Sables . . . 1680. A sheep passant.

Saintes . . . 1758. A jewelled clasp.

St.Esprit, Bagnols 1777. A magpie or crow standing.

Saint Flour . 1785. A squirrel.

St. Germain en $\}$ A wreath or necklace.

St.Jean d'Angely 1779. A tooth.

Saint Lô . . A club.

Saint Malo . 1680. A hammer.

Saint Maixent . A fly.

Saint Martin . 1785. Snuffers.

St. Menehould . 1742. Watering pot.

St. Omer . . A dog passant.

Saint Quentin 1 1748. Sword handle.

Peronne $\cdot$ 1640. A boar.

Salins : $:$ 1640. A boar.

Sedan . . . 1575. Radiated head of Apollo.

Semur en Auxois 1701. Caduceus.

Senlis . . . A kidney bean.

Sens. . . 1745. A helm \& feathers

Soissons . 1734. A helmet, with vizor \& shoulder piece.

Strasbourg . A pear without leaves.f

Tarascon . . Open scissors.

Thouars . . 1714. Head of Mercury.

Toul . . . 1743. Negro's head.

Toulon . . . 1712. A Roman chariot.

Toulouse . . 1500. A trowel.

Tours . . . 1529. A parrot.

Trévoux . . 1783. A vine leaf.

Troyes . . . 1369. A short staff or bell pull.

Valenciennes . 1625. A daisy.

Valognes . . 1750. A head of Apollo to the left.

Vannes . . 1745. An open pod or almond.

Verdun. . . 1630. Fleur de lis.

Versailles, . 1768. A head of a wolf.

Vesoul . . 1775. A cockade or double fan.

Vitry le Français 1614. A head of a soldier with cocked hat.

Uzès . . . 1776. A hawk preparing to mount.

* This, though similar to the pink of Lafere, is bent to the left, the other to the right.

+ As this mark somewhat resembles that of Blois, the name of the town is also marked thus Ro

$\ddagger$ That of Payrat has three leaves. 


\section{INDEX.}

A.

A crowned ........................ $\quad 93$

Abercorn, Marquis, collection...... 64

Addington, S., collection............ 31

Alexander, Mrs., collection ......... 59

All Souls' College, Oxford...........54, 59

Alloy of gold and silver ............ 3

Alphabetical marks...11, 12, 45, 53-64,

68-75

Alphabetical table of French town

marks.

Amphora, a mark ...................... 97

Amsterdam hall marks .............94, 97

Anathema cup ...................... 52

Anne, Statute of .................... 43

Antholin, St., collection ........... 60

Antwerp hall marks ................. 96

Apostle spoons ................29-31, 53

Aqua fortis, assay by........... .100

Arrows at Shrovetide............$\quad 17$

Articuli super cartas................ 4

Ashford, Dr., collection...17, 29, 30, 31, 53-64, 93

Assay, account of thé .............. 35

Assay, exemptions from .......... 41

Assay marks ...6, 11, 12, 14, 15, 19, 35, $36,46,98-110$

Assay, method of ........4, 24, 25, 100

Assay office letters, Birmingham.. 74

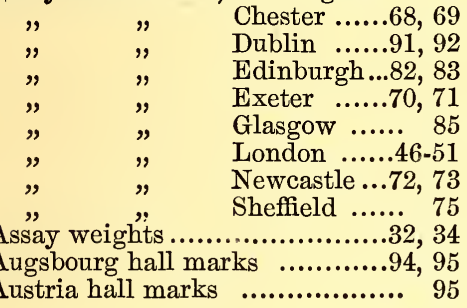

B.

Barber Surgeons' collection ...... 54

Baring, C., collection ............... 59

Barum, a mark .................... 29

Bateman, Lord, coll. ......64, 66, 67, 90

Bear, a mark ......................... 97

Beckett's, Thomas à, cup ........ 52

Belgium hall marks ................... 96

Bell of silver ........................ 17

Bergen hall marks .................. 97

Berne hall marks .................94, 97

Biberach hall marks ................. 96

Biel hall marks ........................ 96

Birmingham appointed to assay... 21, $22,43-45$

BIRMINGHAM assay office letters.. 74

Boar's head, a mark ................. 106

Boileau, Etienne .................... 98

Bond, I., collection ................... 66

Bowes, Sir M., cup ................. 55

Breda hall marks .................. 97

Bremen hall marks .................. 96

Brett, I. W., collection.............. 67

Bristol assay office......... 8, 15, 19, 24

Bristol Corporation plate ... 57, 60, 66
Britannia standard mark $14,19,33,44$

Broderers' Company plate ......... 59

Broomfield church .................. 60

Brownlow, Earl, collection......... 65

Bruges silver ....................77, 102

Brussels hall marks ................ 97

Burgundy hall marks .............. 97

Butler, P., collection ......... 61, 62, 64

C.

Cambridge, Duke, collection ...... 56

Carat defined .......................32, 34

Carpenters' Company plate ...... 59

Castle, a mark..............70, 81, 82, 96

Chaffers, W., collection ............ 29

Charge and Discharge .............. 102

Charles II. cup ..................... 62

Chester assay office...15, 17, 18, 24, 45

CHESTER assay office letters ...68, 69

Chimera, a mark ................. 106

Christ's Coll., Cambridge...53, 54, 56,.58

Christ's Coll., Oxon................. 54

Chronological list of plate...........52-67

Chronological table of marks...... 43

Church ornaments, gilt ........... 8

Citadel, a mark ........................ 96

City or borough mark .............. 7

Cleves hall marks ................... 96

Clifden, Lord, collection .........60, 61

Clothworkers' Company plate ...55, 58

Coblenz hall marks ................. 96

Cock, a mark ........................ 104

Cock's head, a mark ................... 104

Cockayne cups......................58, 59

Coins converted into plate ........ 14

Cologne hall marks ................. 95

Cologne pound ......................... 95

Contremarque .......................99, 106

Convoy described ................... 25

Coope, O. E., collection ............ 67

Coopers' Company plate ............ 61

Corpus Xti Coll., Oxon...............53, 57

do. do. Camb. ........53, 56

Coventry assay office .............. 8

Cozier, W., collection ..........29, 56, 59

Crab, a mark ....................... 106

Crescent, a mark ...................... 97

Creyghtouns cup ................... 62

Cross of St. Andrew.................. 28

Crowhurst Church ..................65, 66

Crowns, three, a mark .............. 95

Cupel, assay by ....................... 100

Currency, variations of $\ldots . . . \ldots . . .34$

Cutlers' Company .................... 5, 7

D.

Dagger................................. 96

Dasent, Dr., collection ........... 59

Date marks ....................45, 81, 90

Dawson, Capt., collection ......... 52

Delft hall marks .................... 97

Derby, Earl, collection.............. 85

Dexter, J. P., collection .............55-65

Diet or scrapings for assay .......35, 38

Doccum hall marks ..............94, 97

Dog's head, a mark .................. 106 
Doncaster Corporation plate.....61, 65 Dordrecht hall marks ............. 97 Doyle, P., collection ............63, 67 Dublin assay office ................86-92 DUBLIN assay letters..............91, 92 Dunstan, St. ..................... 40 Duty, acts relating to .............. 40 Duty, amount paid ............... 42 Duty, imposed and repealed ......19-22 Duty, drawback of................. 41 Duty mark of King's head...21, 22, 40 $45,81,86,90$ E.

Eagle, a mark $\quad$....................... 95

Eagle's head, a mark $\quad$.............. 106

Easton, a mark .................. 29

Ecclesiastical utensils .............. 7

EDINBURGH assay letters........82, 83

Edinburgh assay office ...........76-83

Edward I. Statute $\ldots . \ldots \ldots \ldots . . . . .4,42$

Edward III. do. $\quad \ldots \ldots \ldots \ldots \ldots \ldots . . . .5,6$

Edward IV. do. $\quad$.................9, 43

Edward VI. do. $\quad$................ 9

Elizabeth do. ..........10,11,43

Eresby, Lord Willoughby de, collection ......................58, 64

Esterling of England ...............5, 31

Eston, a mark .................. 29

Examples of hall marks .......... 93

Exemptions from assay .......... 41

Exeter ancient marks .........28, 29, 93

ExETER assay letters...............70, 71

Exeter assay office $\ldots . . .15,16,25,28$,

45,70

Exon, a mark....................... 29

F.

Fanshawe, J. G., collection......... 65

Farrer, H., collection ............. 57

Feathers, plume of, a mark ......87, 90

Fish, a mark .................... 96

Fleur de lis, a mark...31, 93, 96, 99-101

Flushing hall marks................ 97

Foreign hall marks ................ 93

Foreign silver stamped in England 88

Fox's (Bishop) spoons ............ 53

France, hall marks ......93, 98, 106-108

Franks, A. W., collection ........53, 57

Frauds of goldsmiths...... $\ddot{11}, 12,21,25$,

$26,36,37$

French marks, table of $\quad . . \ldots \ldots \ldots .106$

French town marks ...........107-108

Frere, H. T., collection...55, 58, 64, 65 G.

Gardner, J. D., collection ...53.56, 61, $63,64,94$

Garrard, Messrs., collection ......57, 63

Geneva (New), assay office $\ldots . .86,87$

George I. Statute .............19, 40, 43

George II. do. ........20, 40, 41, 46

George III. do. $\quad \ldots 21,22,40,43,44$

George IV. do. .................. 43

Gilt Ecclesiastical utensils ........ 7, 8

Giraffe's head, a mark .............. 106

Glasgow assay office............... 84

GLASGOW assay letters .......... 85

Glynne, Sir S., collection........... $5 i$

Goding, W., collection............ 93
Gold, quantity assayed ..........26, 42 Gold, standards of ...... 22, 23, 32, 33, 44 passim

Goldsmiths' Company charters ...5, 7, 9,10

Goldsmiths' Company, account of 2 Goldsmiths' Company, inspection, \&c. ...9, 24

Goldsmiths' Company plate.......55, 56 , $58,62,66$

Goldsmiths' orders ........5, 12, 39, 43

Goldsmiths to strike their marks $13,35,38,39,46$

Goldsmiths to gild silver only ... 8 Goldsmiths to stamp their initials

Goldsmiths' marks of French $14,20,45$ towns ......................107-108

Goldsmiths' marks, plate of (frontispiece) description $\quad . . \quad 39$ Goldsmitbs, news from the......... 36 Grenville, R. N., collection ......... 58 Greuzenbach hall marks ........... 96 Griffin, a mark .................... 96

H.

Haarlem hall marks ..............94, 96 Haberdashers' Company plate...60, 65 Hague hall marks.................... 96 Hainault hall marks.................. 97

Hall marks-England ......... passim do. France ............ 98-108 do. Ireland ........... 86-92 do. Scotland ............ 81-84

Hall hall marks ........................ 96

Hamburg hall marks ............. 96

Hamilton, Duke of, collection ... 94

Hammermen ........................ 77

Hancock ........................... 24, 67

Harp, a mark ............... 86, 87, 90

Hatchet, a mark ................... 96

Head, G. H., collection .............. 60

Hedon Corporation plate......... 61, 62

Hennell, D., Warden ............ 24, 25

Henry I. Statute, earliest mention of the touch .................... 4

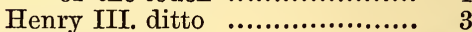

Henry IV. ditto .................... 7

Henry V. ditto ...................... 8

Henry VI. ditto ................ 8, 42

Do. his spoon, boots, \&c... 52

Henry VII. Statute ................ 8

Henry VIII. cup ................... 54

Heriot, Geo. ........................ 78

Hibernia, figure of, a mark ......86-90

Holburne, sir T. W., collection... $58,59,61,63,67$

Holland hall marks ............. 94, 96 Horn, a mark........................ 97 Horse, a mark ..................... 96

Horse's head, a mark .............. 106

Horwod, a mark ..................... 30

Howard of Corby, collection ...... 52

Hughes, Mr. T., of Chester......... 18

Hume, Lord, collection ........... 57

Hungary hall marks................ 31, 96 Hunt and Roskell, collection ...62, 66 Huth, L., collection ........ 56, 57, 58 
I. J.

James II Scots.... James III Scots ................. 77

James VI, Scots...................... 77

James VII, Scots ..................... 78

Jepson, G., collection .............. 64

Jesus College, Oxon ................. 63

Jewellery exempt from assay, ...20, 41

Innholders' Company plate ...54, 58-62

John's College, Cambridge ......... 59

Ireland ........................... 86-92

Ironmongers' Company plate... 54, 64

\section{K.}

Karat, the term discontinued ...... 103

Key, a mark .................... 96, 97

Keyserberg hall marks............... 96

King's head indented ............ 40, 50

King's head duty mark ......... 22, 40

Knight's spurs

Koningsberg hall marks ........... 96

\section{L.}

La Croix quoted 102

Lamerie, Paul, maker ............. 65, 66 Leathersellers' Company plate ... 61

Leake, Sir J., cup .................... 64

Legh, Sir T., cup .................. 53

Leigh, C. H., collection ........... 64

Leopard's head mark ...4, 12, 20, 33, 44

Leopard's head crowned...9, 12, 13, 37

Leroy, P. quoted ................... 99

Letter, Roman ...................... 15

Leyden hall marks ................. 98

License to sell plate ..................21-40

Lincoln assay office ................ 8

Lion passant............11, $12,20,33,44$

Lion's head erased.........14, 19, 33, 44

Lion rampant ..............82, 85, 96, 97

LoNDON assay letters ................46-51

London hall marks.................44, 93

Louis XI. ordinance................ 7

Louis, Saint do. ................. 100

Louis XIV. do. .................. 101

Louis XVI. do. ............... 101

Louis Philippe do. $\quad$................ 105

Lowe, J. F., assay master.......... 18

\section{M.}

Maestricht hall marks ............. 97

Magniac, H., collection ........... 56

Manchester, Duke, collection ...64, 94

Mark of the city or borough ......7, 15

Mark of the King ..................6, 6

Marks, provincial ....... $19,24,25,28$,

$$
\text { 68-75 }
$$

Marks, fraudulent .................. 27

Marks, uncertain English ........ 29

Marks alike on gold and silver...32, 43

Marks, alphabetical ...........11, 12, 45

Marks of assayers......6, 11, 12, 14, 15 , $19,35,46$

Marks, chronological table of...... 43 Marks of makers ...6, $7,11,13,14,19$,$$
\text { do. } 35,38,39,45,81 \text {, }
$$
description of..................... 39

Marlborough plate ................. 64

Maskell, W., collection.............. 63

Mayence hall marks ..............94, 95
Mercers' Company plate ......53, 61, 63 Merchant Taylors' plate ......57, 62, 93 Meyrick, W., collection '............ 66 Millièmes or thousandths ........ 103 Minerva, head of, a mark ........ 106 Montacute, Earl...................... Morgan, O., collection ......28, 58, 59, 62,64

Moscow hall marks ................ 97 Mostyn, G., collection ............... 66

Mourning rings .................... 41

N.

$\mathrm{N}$ as a mark

Napier, R., collection ................ 57

Newcastle, arms of ................ 19

Newcastle assay office...8, $15,16,24,45$

NeWCAstLE assay letters.........72, 73

Newcastle Corporation plate ...... 63 New Geneva assay office .........87, 88 Norwich assay office $\ldots 8,15,16,24,45$ Norwich stamp on plate ........... 31 Norwich Corporation plate ......58, 59, 65,66
Nuremberg hall marks ...........94, 95

O.

Oar of silver ........................ 65

Orange hall marks ................ 97

Owen, H., collection ....................

Oxford Corporation plate $\ldots . . . . .6 \quad 62$

P.

Painters' Company plate........ 53, 60 Paris and departments, table of marks

Paris touch ................... 4, 5, 99 Paris hall marks ................. 93, 106 Parker, Archbishop ........ 53, 54, 55 Pelican cup ............................ 57 Pembroke Coll. plate ................. 52 Petersburg hall marks ............ 94, 97 Physician, head of, a mark ......... 106 Pine apple, a mark ............... 95 Plate, chronological list of ....... 52-67 Poincon de Paris ............. 100, 104 Pound weight of Cologne ........ 95 Prague hall marks $\quad$.................. 96 Prior, M., assayer .................. 24 Provincial marks little known ... 19 Provincial marks ......7, 19, 24, 25, 28,

Provincial offices $\ldots \ldots \ldots \ldots, 4,5,10$ Prussia hall marks ................. 95 Puncheons of steel ................ 37

Q.

Queen's Coll., Oxon., plate ..... 60-62 Queen, H. M., collection..63, 66, 67, 94 R.

Radcliff, a mark 29,93 Rainey, I., collection ......... 54, 56, 62 Ratisbon hall marks ................. 96 Ravensberg hall marks.......... .96 Recense, poinçon de ........... 104-106 Remedy, what it is ............ 101, 104 Report of Committee ........... 23, 26 Revolution, French ........... 102, 103 Rhinoceros head, a mark........... 106 
Richard II. Statute $\ldots . \ldots \ldots .6, \mathbf{7}, 42$

Richmond, Countess of ........... 53

Rome hall marks ................ 94, 97

Rose crowned, a mark ........... 31, 93

Rosnel, P., quoted.................. 101

Rothschild, L., coll.....56, 57, 62, 63, 94

Rushworth. F., assayer............. 24

Russian plate...................... 95, 96

Rutland, Duke of, plate ........ 57, 63

Saddle, a mark .................. 96

Salford museum collection .......... 30

Salisbury assay office ............... 8

Salisbury, Bishop of ................ 4

Sanford, E. A., collection ......... 55

Saxony hall marks ............. 94, 95

Sayers' marks..... 6, 11, 12, 14, 15, 19

Scasebrick, M., assayer ........... 24

Schaffhausen hall marks ........... 97

Scotch coins, gold.................... 34

Scotland ............................ 76-82

Scrapings for assay ............... 35, 38

Search of goldsmiths ......... 9, 10,37

Sewell, Mr., Newcastle............. 19

Sheffield assay office ......21, 22, 24, 45

SHEFFIELD assay letters........... 75

Silver, price at the Mint ............ 14

Silver articles liable to assay ...... 41

Silver articles subject to duty...... 41

Silver for exportation...............15, 41

Silver, quantity assayed...........26, 42

Silver, standard of...3, $5,11,14,15,19$, $24,31,32,44$

Skinner, assayer $\quad . . . . . . . . . . . . . . .224$

Skinners' Company plate....58, 60, 61, 63

Slade, F., collection ................. 93

Smith, M. T., collection ............. 30

Solder, its limit..................... 20

South Kensington Museum...29, 31, 52, $60,63,67,93,94$

Spain hall marks .................... 97 Spencer, Earl, collection ..........62, 64 Spilsbury, silversmith ............... 24 Stag's horns, a mark................... 95 Stamford, Earl, collection.........64, 65 Standard of fineness ......3, 11, 14, 15 Standard gold 22 carats ....32, $33,81,88$ Standard gold 18 carats ...9, 22, 32, 33, 81,88 33,88

Standard, new, ordained............ 14

Standard, old, revived .............. 19 Standard, various $. . .31,32,33,34,44$, $79,81,88$

Standard, debased ...11, 31, 33, 44, 88 Standards of Scotland and Ireland

$79,81,89,90$

Standard of France ..............98-106

Staniforth, T., collection ..........30, 31, 53-64, 93

Star, a mark .................. 97

Statutes, table of ..................... 1 Statutes, extracts from........3-33, 76,80 Sterling of England.................5, 31 Stirling, W., collection ......60, 65, 67 Stopford, W. B., collection ......... 62
Stork, a mark $\quad$ PAGR

Sweden hall marks $\ldots . . . . . . . . . . . . .997$

Swords, a mark '....................... 95

Sword and arrow, a mark ........ 96

$\mathrm{T}$.

Table of Statutes

Table of assay letters :-

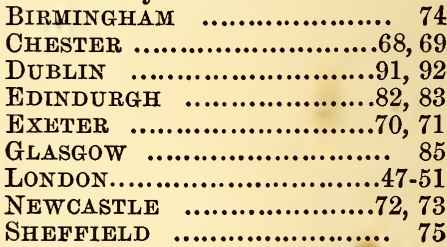

SHEFFIELD .....................

piece) $\ldots \ldots \ldots \ldots \ldots \ldots \ldots . \ldots \ldots, 39$

Table of variations of standard coins 34

Thistle, a mark ....................79, 81

Thomas à Becket's cup.............. 52

Touch of Paris ....................... 4, 5

Touch stone and needle $\quad . .3,4,19,37$

Touch warden ....................... 38

Tree, fish and bell, a mark ......81, 84

Trevelyan, W. C., collection ...... 63

Trial of gold and silver ............ 36

Trinity Coll., Oxon. plate ........ 54

Troy weights .........................10, 96

U. V.

Verification, stamp of ........ 104-106

Victoria. Statutes..22, 27, 33, 43, 44, 88

Vintners' Company plate ... 54, 55, 61

Vienna hall marks .............. 94, 95

Unicorn's head, a mark ........ 87, 90

Utrecht hall marks .............. 94, 96 W.

Walrond, I. W., collection ......... 62

Wardrobe accounts ................. 102

Watches and plate exported .... 15, 41

Watch cases exempt from duty ... 40

Watch cases, quantity assayed ... 23

Watch cases, French................. 106

Watchmakers of New Geneva... 86,87

Waterton, E., collection ............ 94

Watson, I., assay master ........... 22

Wax Chandlers' Company plate... $\quad 55$

Wedding rings ....................... 33

Weevil, a mark ......................... 106

Weigher sworn ..................... 38

Westminster Abbey plate ...... 62, 63

Westphalia hall marks............... 96

Wheel, a mark ...................... 44

William III. Statute ... 13, 15, 43, 56

William IV. ditto ................. 79

Willoughby, Lord, collection ...58, 64

Winn, C., collection ................... 59

Wolf, a mark........................... 95

Worms hall marks...................... 96

Wurtemburg hall marks ......... 94, 95 $\mathrm{x}$.

$\mathrm{X}$ crowned, a mark ........ 28, 29, 93 Y.

Yeds, a mark ......................... 29

York assay office ........ 8, 15, 16, 24, 44

York Corporation plate ........... 62

THE END. 
BY THE SAME AUTHOR,

Third Edition, revised and considerably augmented, price 28 .

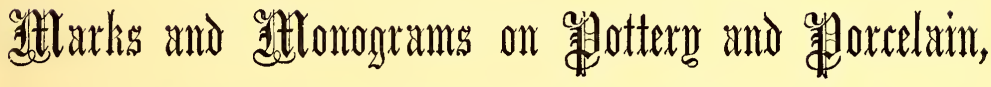
OF THE RENAISSANCE AND MODERN PERIODS,

WITH HISTORICAL NOTICES OF EACH MANUFACTORY;

PRECEDED BY

AN INTRODUCTORY ESSAY ON THE VASA FICTILIA OF ENGLAND.

WITH 2200 POTTERS' MARKS AND ILLUSTRATIONS.

J. DAVY \& SONS, 137, LONG ACRE. 







\section{.}






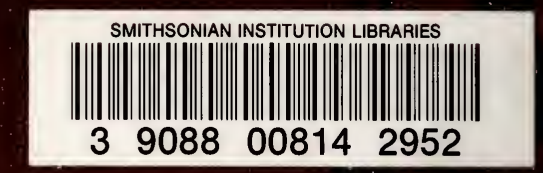

